Clemens, S.C., Kuhnt, W., LeVay, L.J., and the Expedition 353 Scientists Proceedings of the International Ocean Discovery Program Volume 353 publications.iodp.org

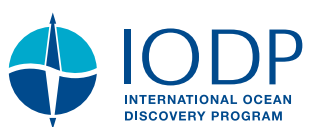

\title{
Contents
}

doi:10.14379/iodp.proc.353.101.2016

\section{Expedition 353 summary ${ }^{1}$}

CrossMark \&lick for updates

S.C. Clemens, W. Kuhnt, L.J. LeVay, P. Anand, T. Ando, M. Bartol, C.T. Bolton, X. Ding, K. Gariboldi, L. Giosan, E.C. Hathorne, Y. Huang, P. Jaiswal, S. Kim, J.B. Kirkpatrick, K. Littler, G. Marino, P. Martinez, D. Naik, A. Peketi, S.C. Phillips, M.M. Robinson, O.E. Romero, N. Sagar, K.B. Taladay, S.N. Taylor, K. Thirumalai, G. Uramoto, Y. Usui, J. Wang, M. Yamamoto, and L. Zhou ${ }^{2}$
1 Abstract

1 Introduction

2 Objectives

2 Background

10 Site summaries

27 Expedition 353 synthesis

27 Expedition 353 science assessment

28 References

Keywords: International Ocean Discovery Program, IODP, Expedition 353, JOIDES Resolution, Site U1443, Site U1444, Site U1445, Site U1446, Site U1447, Site U1448, Indian monsoon, monsoon, Bay of Bengal, Andaman Sea, paleoclimate, paleoceanography, Miocene, Pliocene, Pleistocene, Holocene, Cretaceous, Paleogene, Ninetyeast Ridge, Indian Ocean, salinity, Bengal Fan, orbital, millennial, centennial, abrupt climate change

\section{Abstract}

International Ocean Discovery Program (IODP) Expedition 353 (29 November 2014-29 January 2015) drilled six sites in the Bay of Bengal, recovering $4280 \mathrm{~m}$ of sediments during 32.9 days of on-site drilling. Recovery averaged 97\%, including coring with the advanced piston corer, half-length advanced piston corer, and extended core barrel systems. The primary objective of Expedition 353 is to reconstruct changes in Indian monsoon circulation since the Miocene at tectonic to centennial timescales. Analysis of the sediment sections recovered will improve our understanding of how monsoonal climates respond to changes in forcing external to the Earth's climate system (i.e., insolation) and changes in forcing internal to the Earth's climate system, including changes in continental ice volume, greenhouse gas concentrations, sea level, and the ocean-atmosphere exchange of energy and moisture. All of these mechanisms play critical roles in current and future climate change in monsoonal regions.

The primary signal targeted is the exceptionally low salinity surface waters that result, in roughly equal measure, from both direct summer monsoon precipitation above the Bay of Bengal and runoff from the numerous large river basins that drain into the Bay of Bengal. Changes in rainfall and surface ocean salinity are captured and preserved in a number of chemical, physical, isotopic, and biological components of sediments deposited in the Bay of Bengal. Expedition 353 sites are strategically located in key regions where these signals are the strongest and best preserved. Salinity changes at IODP Sites U1445 and U1446 (northeast Indian margin) result from direct precipitation as well as runoff from the Ganges-Brahmaputra river complex and the many river basins of peninsular India. Salinity changes at IODP Sites U1447 and U1448 (Andaman Sea) result from direct precipitation and runoff from the Irrawaddy and Sal- ween river basins. IODP Site U1443 (Ninetyeast Ridge) is an openocean site with modern surface water salinity very near to the global mean but is documented to have recorded changes in monsoonal circulation over orbital to tectonic timescales. This site serves as an anchor for establishing the extent to which the north to south $\left(19^{\circ} \mathrm{N}\right.$ to $5^{\circ} \mathrm{N}$ ) salinity gradient changes over time.

\section{Introduction}

The R/V JOIDES Resolution has conducted scientific ocean drilling in many of the marginal basins surrounding monsoon-influenced regions of India and Asia including the Arabian Sea (Ocean Drilling Program [ODP] Leg 117), the South China Sea (ODP Leg 184 ), the East China Sea (Integrated Ocean Drilling Program Expedition 346), and the marginal sea bordered by the Eurasian continent, the Korean Peninsula, and the Japanese Islands (Expedition 346). Sediments recovered have been used to reconstruct changes in summer monsoon upwelling and eolian transport (Leg 117), summer and winter monsoon surface and intermediate water dynamics in the northern and southern regions of the South China Sea (Leg 184), the influence of the westerlies on monsoonal circulation in the marginal sea bordered by the Eurasian continent, the Korean Peninsula, and the Japanese Islands (Expedition 346), and the influence of Yangtze River runoff on the surface waters of the East China Sea (Expedition 346). These records will be complemented by future drilling during scheduled International Ocean Discovery Program (IODP) expeditions in the Eastern Arabian Sea (Expedition 355), the Maldives (Expedition 359), and the Timor Sea (Expedition 363) (Figure F1). Prior to Expedition 353, however, no scientific drilling has occurred in the core convective region of the IndoAsian monsoon system, the northern Bay of Bengal. Expedition 353 fills this scientific/geographic gap by drilling targets in the Bay of

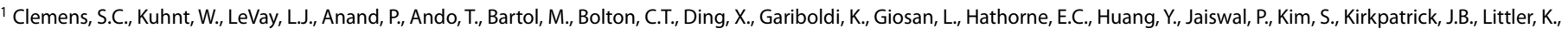
Marino, G., Martinez, P., Naik, D., Peketi, A., Phillips, S.C., Robinson, M.M., Romero, O.E., Sagar, N., Taladay, K.B., Taylor, S.N., Thirumalai, K., Uramoto, G., Usui, Y., Wang, J., Yamamoto, M., and Zhou, L., 2016. Expedition 353 summary. In Clemens, S.C., Kuhnt, W., LeVay, L.J., and the Expedition 353 Scientists, Indian Monsoon Rainfall. Proceedings of the International Ocean Discovery Program, 353: College Station, TX (International Ocean Discovery Program). http://dx.doi.org/10.14379/iodp.proc.353.101.2016

${ }^{2}$ Expedition 353 Scientists' addresses.

MS 353-101: Published 29 July 2016
} 
Figure F1. ODP and IODP monsoon-related expeditions. Satellite image from Stöckli et al. (2005).

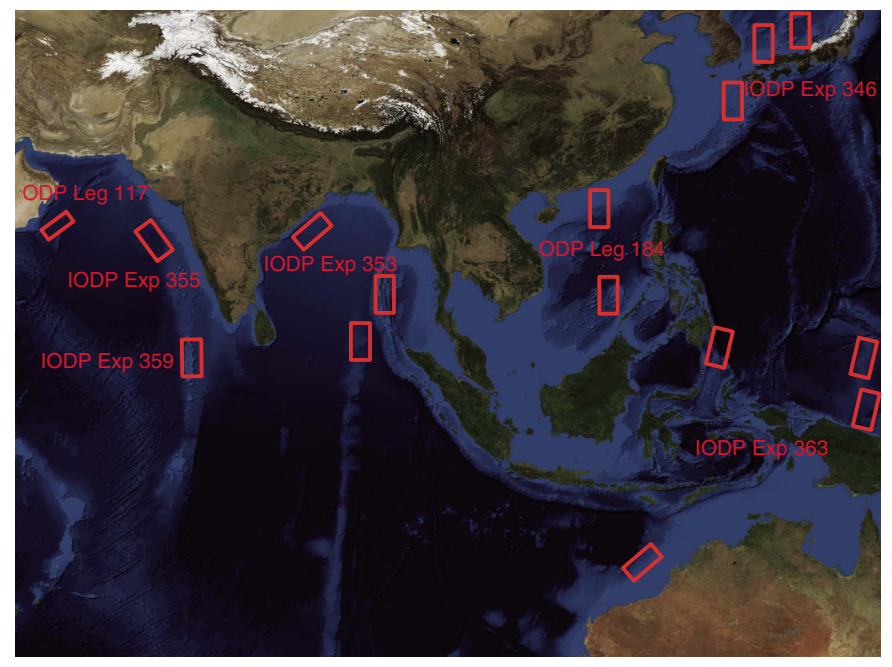

Figure F2. Location of Expedition 353 sites and seafloor depths. Map was generated using GeoMapApp (http://www.geomapapp.org), using topography and bathymetry from the Global Multi-Resolution Topography synthesis (Ryan et al., 2009).

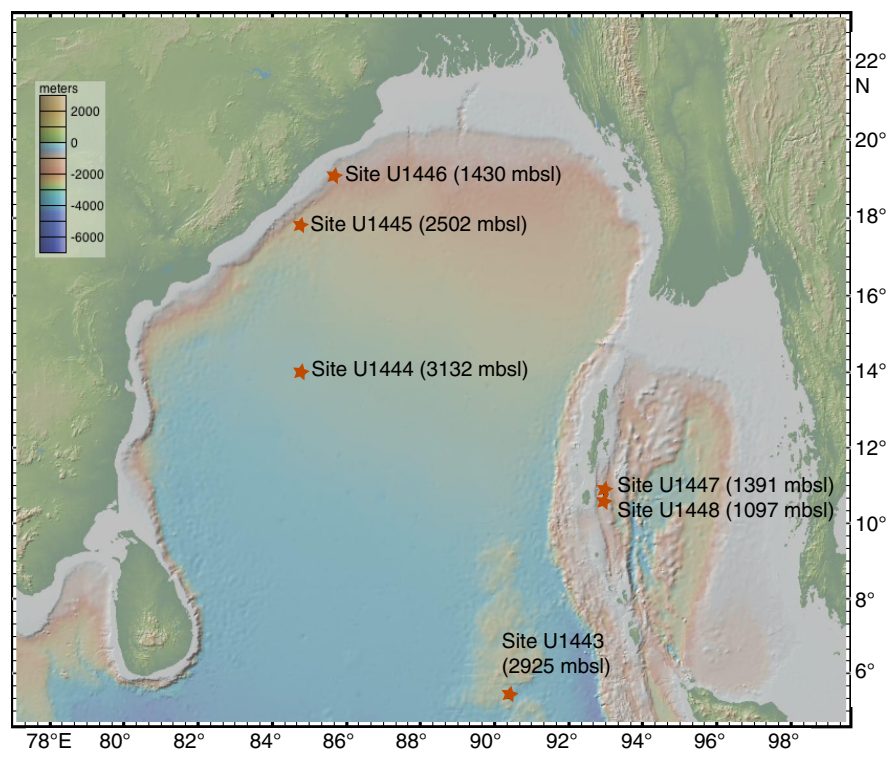

Bengal that $\operatorname{span} 5^{\circ} \mathrm{N}$ to $20^{\circ} \mathrm{N}$ (Figure F2). Analysis of these sediments will help to address the scientific objectives outlined below. Scientific drilling last occurred in the Bay of Bengal in 1972 (Deep Sea Drilling Project Leg 22) when the D/V Glomar Challenger drilled Sites 217 and 218 in the southernmost Bay of Bengal $\left(8^{\circ} \mathrm{N}\right.$ to $\left.9^{\circ} \mathrm{N}\right)$. Scientific studies performed on India's National Gas Hydrate Program Expedition 1 cores collected aboard the JOIDES Resolution in 2006 (Collett et al., 2008; Ramana et al., 2014), which provided the foundation for selecting most of the sites for Expedition 353, indicate the excellent potential for paleoclimatic and paleoceanographic reconstructions in the region (i.e., Ponton et al., 2012; Cawthern et al., 2014; Flores et al., 2014; Johnson et al., 2014; Phillips et al., 2014a, 2014b; Ali et al., 2015).

\section{Objectives \\ Pliocene-Pleistocene}

- Establish the sensitivity and timing of changes in monsoon circulation relative to insolation forcing, latent heat export from the Southern Hemisphere, global ice volume extent, and greenhouse gas concentrations;

- Determine the extent to which Indian and East Asian monsoon winds and precipitation are coupled and at what temporal and geographic scales;

- Better separate the effects of climate change and tectonics on erosion and runoff;

- Provide verification targets for climate models, including the rapidly evolving water isotope-enabled, time-dependent models; and

- Understand the relationship between Indian monsoon variability and the Pliocene-Pleistocene intensification of Northern Hemisphere glaciation.

\section{Campanian-Miocene}

- Understand the timing and conditions under which monsoonal circulation initiated and reconstruct the variability of the Indian monsoon at orbital timescales; and

- Understand the relationship between Indian monsoon variability and major past global climatic events such as Oligocene/Miocene cooling (Zachos et al., 1997), the onset of the mid-Miocene climatic optimum (Holbourn et al., 2007, 2015; Zachos et al., 2001), and mid-Miocene cooling and Antarctic cryosphere expansion (Holbourn et al., 2013, 2014).

\section{Oligocene-present}

- Establish a complete Oligocene-present astronomically tuned timescale based on high-resolution benthic and planktonic isotope reference curves for the Indian Ocean, and

- Integrate high-resolution distribution studies of well-preserved Oligocene-recent calcareous and siliceous microfossils from the Indian Ocean into global compilation studies of paleoclimatic and biotic evolution.

\section{Background}

\section{Motivation for drilling in the Bay of Bengal}

\section{Pliocene-Pleistocene}

The three regions chosen for drilling during Expedition 353 (Mahanadi basin, Andaman Islands, and northern Ninetyeast Ridge) delineate a north-south transect designed to capture past changes in the exceptionally strong salinity gradient observed in the modern Bay of Bengal $\left(19^{\circ} \mathrm{N}\right.$ to $\left.5^{\circ} \mathrm{N}\right)$. A threefold motivation exists for targeting this precipitation/salinity signal.

First, the Bay of Bengal/Andaman Sea and surrounding catchments are within the Earth's strongest hydrological regime (Figure F3), impacting billions of people; a solid understanding of the physics behind monsoonal climate change is of significant societal relevance (Nicholls et al., 2007). The net annual surface water exchange (precipitation plus runoff minus evaporation) within the Bay of Bengal and Andaman Sea during the summer monsoon is $184 \times$ $10^{10} \mathrm{~m}^{3}$, dominating the winter signal of $-32 \times 10^{10} \mathrm{~m}^{3}$ for an annual average of $152 \times 10^{10} \mathrm{~m}^{3}$ (Varkey et al., 1996). The effects of this 
Figure F3. Climatological (A) July-August and (B) January-February mean precipitation rates (shading in $\mathrm{mm} /$ day) and $925 \mathrm{hPa}$ wind vectors (arrows). Precipitation and wind climatology are derived from CMAP (Xie and Arkin, 1997) (1979-2000) and NCEP/NCAR reanalysis (1951-2000), respectively.

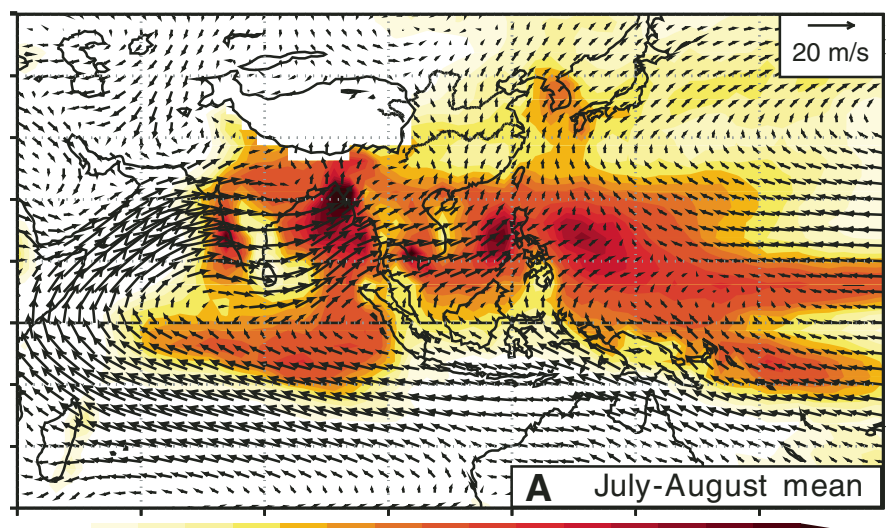

$\begin{array}{llllllllllllllll}2 & 3 & 4 & 5 & 6 & 7 & 8 & 9 & 11 & 12 & 13 & 14 & 15 & 16 & 17 & 18\end{array}$

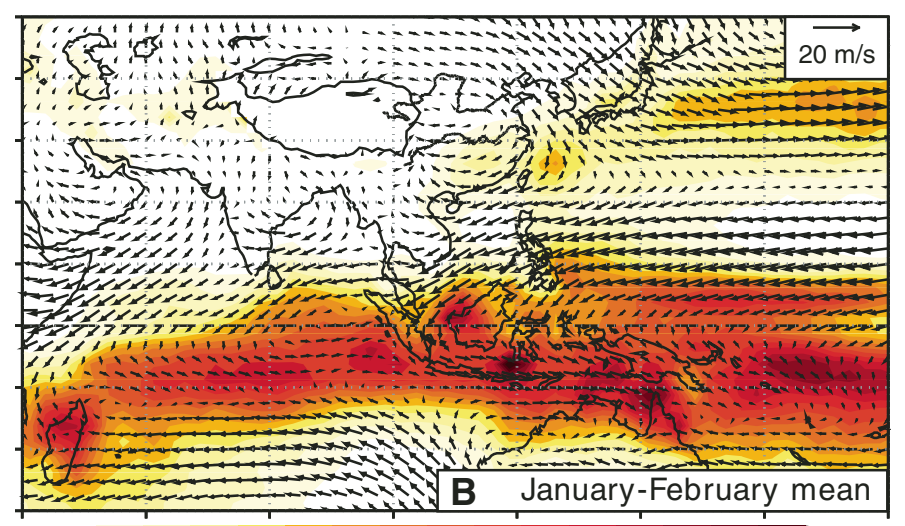

$\begin{array}{llllllllllllllll}1 & 2 & 3 & 4 & 5 & 6 & 7 & 8 & 9 & 10 & 11 & 12 & 13 & 14 & 15 & 16\end{array}$

(mm/day)

budget are clearly evident in the surface salinity climatology (Figure F4) (Antonov et al., 2010), indicating a well-defined, strong signal that can be used to monitor changes in monsoonal precipitation via chemical, physical, and isotopic indicators for changes in precipitation, salinity, and terrestrial erosion/runoff. The extent of the lowsalinity surface waters is sufficient to mute (via stratification) what would otherwise yield strong summer season productivity in response to wind-driven upwelling along the eastern Indian margin, similar to that seen in the Arabian Sea (Guptha et al., 1997; Kumar et al., 2002; Phillips et al., 2014b). Hence, the Bay of Bengal is optimal for isolating and recording the summer monsoon precipitation signal in that the vast majority of precipitation, sourced from the Southern Hemisphere Indian Ocean, occurs during boreal summer (Figure F5).

Second, recent studies have called into question the extent to which basin-scale monsoon winds and continental precipitation are coupled over a range of timescales and spatial scales (Clemens et al., 2010; Clemens and Prell, 2007; Liu et al., 2006; Molnar, 2005; Ruddiman, 2006; Wang et al., 2008; Ziegler et al., 2010). Nearly all proxy records indicate strong coupling between summer monsoon winds and precipitation across the Indo-Asian monsoon subsystems at the millennial scale (Altabet et al., 2002; Cai et al., 2006; Clemens, 2005; Schulz et al., 1998; Sun et al., 2011; Wang et al., 2001); this tight coupling is likely attributed to the strong role of the winter westerlies in coupling high- and low-latitude climate change. However, the physical mechanisms behind these links are not fully understood; this was a primary goal of Expedition 346. Progress is also being made in understanding winter monsoon and summer monsoon linkages at the millennial timescale. For example, recent work offshore Goa, western India, shows synchronous breakdown in summer and winter monsoon airflow over the Arabian Sea during Heinrich events (Singh et al., 2011), which is in contrast to the East Asian Monsoon system that shows an asynchronous relationship between summer and winter monsoon strength at the millennial scale (Yancheva et al., 2007).

Consensus does not yet exist on the extent of the coupling or the ultimate forcing of monsoon winds and precipitation at orbital and longer timescales (An et al., 2011; Caley et al., 2011a, 2011b, 2011c; Cheng et al., 2009; Clemens and Prell, 2007; Clemens et al., 1996, 1991, 2008; Clift et al., 2008; Ruddiman, 2006; Wang et al., 2008; Ziegler et al., 2010). Some argue for close coupling between changes in Indian and East Asian summer monsoon winds and precipitation across the entire region spanning the Arabian Sea (Leg 117), the South China Sea (Leg 184), and terrestrial records from eastern China. In this case, changes in the strength of summer monsoon circulation across these regions are thought to be sensitive to Northern Hemisphere sensible heating (insolation), the timing of energy release from the Southern Hemisphere Indian Ocean, and the timing of global ice volume minima (An et al., 2011; Caley et al., 2011b, 2011c; Clemens and Prell, 2003, 2007; Clemens et al., 1996, 2008). In contrast, others interpret the timing of summer monsoon circulation on the basis of speleothem records from southeast China, as forced directly by external insolation with little or no influence from internal boundary conditions such as ice volume or Southern Hemisphere ocean-atmosphere latent heat exchange (Cheng et al., 2009; Ruddiman, 2006; Wang et al., 2008). CaballeroGill et al. (2012) demonstrate that these contrasting interpretations are not attributable to differences in terrestrial and marine chronologies. Therefore, this lack of consensus points either to a strong deficit in our understanding of monsoon sensitivity to changes in the fundamental boundary conditions including insolation, ocean/atmosphere energy exchange, ice volume, and atmospheric greenhouse gas concentrations or to the confounding influence of seasonality on interpretation of proxy records. The latter is illustrated in Figure F5 where rain-bearing air masses span both winter and summer seasons (eastern China cave region, lower panel), whereas rain-bearing air masses are strongly biased toward the summer season for the Mahanadi basin (upper panel).

Lack of consensus also extends to the tectonic scale, where the timing of monsoon intensification to modern strength is debated. Some proxy records suggest intensification occurred at $\sim 7-8 \mathrm{Ma}$ (e.g., Kroon et al., 1991; Prell et al., 1992), whereas others suggest a considerably earlier intensification, perhaps as early as early Miocene ( 22 Ma) (Clift et al., 2008; Guo et al., 2002; Sun and Wang, 2005) or even late Eocene ( $45 \mathrm{Ma}$ ) (Licht et al., 2014). Emergence and expansion of arid-adapted $\mathrm{C}_{4}$ flora in South Asia argues for reduced precipitation since $\sim 8 \mathrm{Ma}$ (e.g., Cerling et al., 1997; Huang et al., 2007; Quade and Cerling, 1995), whereas proxies dedicated to reconstructing seasonality instead suggest little variability in the monsoon over the last $10 \mathrm{My}$ (Dettman et al., 2001). Clift and Plumb (2008), Molnar et al. (2010), and the report from the Detailed Planning Group "Asian Monsoon and Cenozoic Tectonic History" (http://www.iodp.org/doc_download/2336-mmdpgreport) provide comprehensive overviews of these issues. More recently, Rodriguez et al. (2014) suggested that the $\sim 8 \mathrm{Ma}$ intensification inferred 
Figure F4. World Ocean Atlas Monthly Mean Salinity for 1955-2006 (Antonov et al., 2010). Areas drilled in the Andaman Sea (Sites U1447 and U1448), Mahanadi basin, northern Bay of Bengal (Sites U1445 and U1446), and Ninetyeast Ridge (Site U1443) are shown.
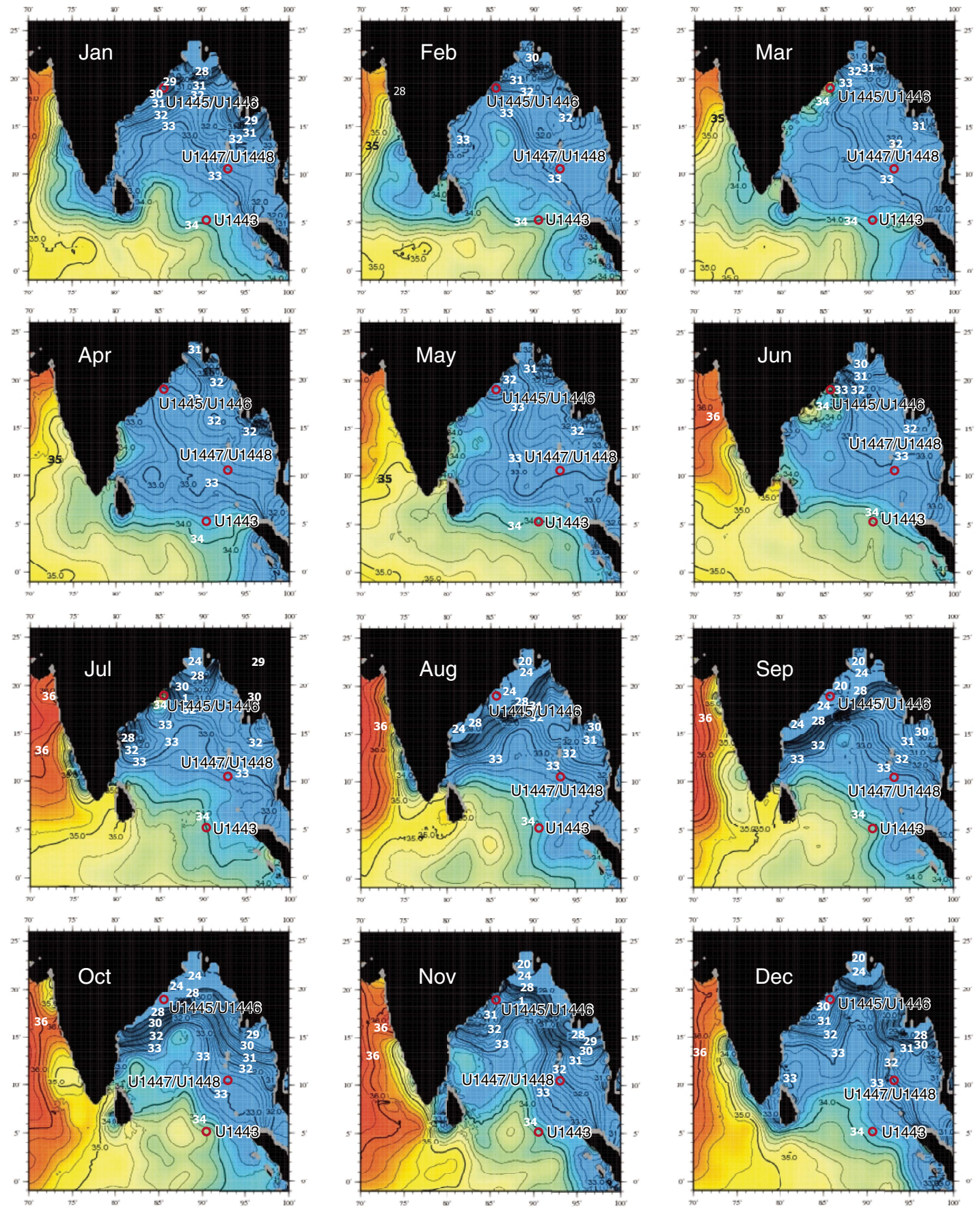

on the basis of increased Globigerina bulloides concentrations may be an artifact related to uplift of the Owen Ridge at this time, resulting in enhanced carbonate preservation. This, however, cannot account for the similar signal observed in the radiolarian assemblage data (Prell et al., 1992).

Third, recent work suggests that interpretation of the oxygen minimum zone (OMZ) signal in the northern Arabian Sea (Leg 117) may be complicated by changing oxygen content of southern-source intermediate waters (Anand et al., 2008; Caley et al., 2011c; Schmittner et al., 2007; Ziegler et al., 2010). This presents a potential com- plication in the interpretation of the OMZ signal as a direct response to atmospheric circulation in the core region of summer monsoon winds (i.e., oxygen drawdown in response to decay of upwelling-produced organic carbon). Precipitation, salinity, and runoff indicators are not influenced by the chemistry of externally sourced intermediate and deep water masses, offering the potential to disentangle the influences of these factors in interpreting monsoon proxy records.

The Expedition 353 drilling effort, targeting the core geographic region of summer monsoon precipitation, directly addresses these 
Figure F5. Ten-day National Oceanic and Atmospheric Administration HYSPLIT backtracks (2007-2011). Green indicates rain-bearing air trajectories. Rain-bearing trajectories over India are dominated by summer season (southwest) winds, whereas both winter (northerly) and summer (southerly) air masses carry precipitation to the monsoonal region of eastern China. This is consistent with World Meteorological Organization rainfall records indicating that June, July, and August rainfall only accounts for $50 \%$ of the total annual rainfall in eastern China. The Bay of Bengal location isolates summer season dynamics.
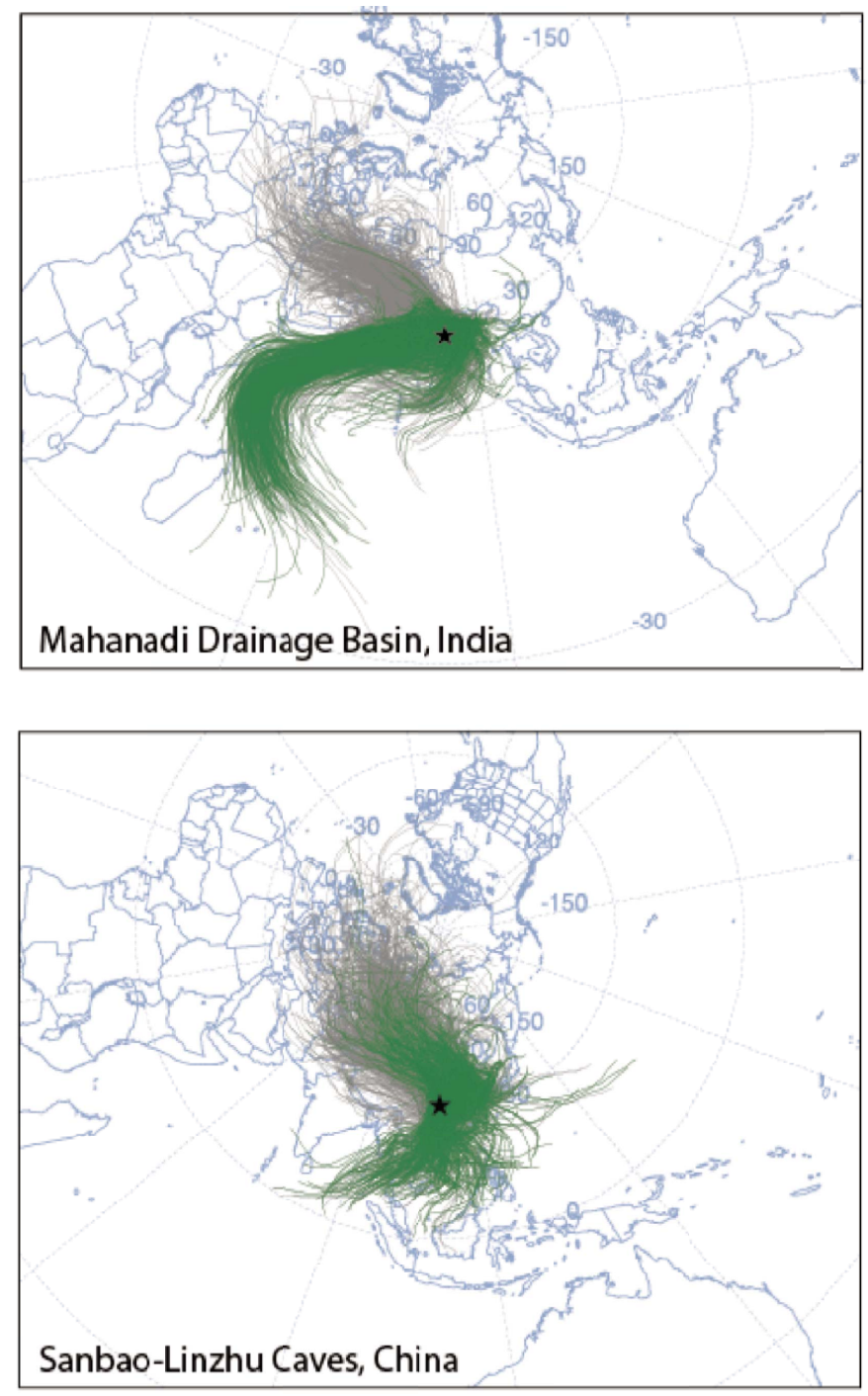

outstanding issues. Resolving these questions using the geological archive is important for providing verification targets for climate models, especially given that the majority of current AtmosphereOcean General Circulation Models used in the Intergovernmental Panel on Climate Change reports do not accurately simulate the spatial or intraseasonal variability of monsoon precipitation (Randall et al., 2007; Sharmila et al., 2015).

\section{Deep time}

Benthic foraminiferal diversity and assemblage composition, in conjunction with geochemical proxies of carbon flux, indicate a stepwise increase in primary production and carbon flux and an expansion of the intermediate water OMZ in the northeastern Indian Ocean since the late Oligocene (Gupta et al., 2013). The main in- creases in productivity started at 14 Ma (Gupta et al., 2013) or 10 Ma (Gupta et al., 2004) and reached levels associated with present Indian monsoon conditions around 2.3 Ma. This late Miocene to Pliocene "biogenic bloom" (Farrell et al., 1995) implies important changes in nutrient cycling in the Indian Ocean and probably on a global scale, which in particular affected the silica and phosphorus cycles (Dickens and Owen, 1999). The productivity increase between 10 and $8 \mathrm{Ma}$ in the eastern equatorial Indian Ocean (onset of the biogenic bloom) may have been linked either to global cooling and the expansion of Antarctic ice sheets leading to a major change in deep ocean circulation and nutrient cycling, to the initiation of the Indian monsoons, or to a combination of both (Gupta et al., 2004).

Deep-sea benthic foraminiferal diversity in the Indian Ocean further decreased between 8 and $6 \mathrm{Ma}$ and is associated with a negative $\delta^{13} \mathrm{C}$ shift at 3.2-2.3 and 1.6-0.9 Ma, coinciding with an increased abundance of species indicative of increased organic carbon flux (Singh and Gupta, 2005). Since $\sim 2.8 \mathrm{Ma}$, roughly coeval with the onset of Northern Hemisphere glaciation, benthic foraminiferal species that are well adapted to seasonally strong fluctuating carbon flux dominate the assemblages. This has been related to increased duration and strength of the northeast (winter) monsoon, which is accompanied by relatively low primary production in the eastern equatorial Indian Ocean (Gupta and Thomas, 2003). Expedition 353 will provide new Neogene intermediate water benthic foraminiferal assemblage, $\delta^{18} \mathrm{O}$, and $\delta^{13} \mathrm{C}$ records along a meridional transect to better understand the relative contribution of monsooninduced changes in carbon flux and changes in intermediate water circulation linked to high-latitude climatic events such as fluctuations in the extension of the East Antarctic ice sheet. Analysis of Bay of Bengal surface sediments indicates that the foraminiferal lysocline, the depth delimiting well-preserved from noticeably dissolved assemblages, shoals significantly from south to north. The foraminiferal lysocline rises from 3800 to $3300 \mathrm{~m}$ between $0^{\circ} \mathrm{N}$ and $7^{\circ} \mathrm{N}$ (about Site U1443) then systematically shoals to $\sim 2000 \mathrm{~m}$ at $\sim 20^{\circ} \mathrm{N}$ (Indian margin sites) (Cullen and Prell, 1984), indicating enhanced carbon flux to the deep sea in the northern part of the Bay of Bengal.

The Expedition 353 meridional transect provides a unique opportunity to investigate the nature and timing of variations in deepwater radiogenic isotope composition in response to restriction of the deepwater connection between the Pacific and Indian Oceans through the Indonesian Gateway since the mid-Miocene. Compared to the fan sediments of IODP Expedition 354, Expedition 353 sediments will help to disentangle climatic variability from direct tectonic influences using non-Himalayan sedimentary sequences on the Indian continental margin, and to evaluate the influence of enhanced Himalayan erosion since the late Oligocene at sites affected by a Himalayan signal in Andaman Sea and Ninetyeast Ridge sediments.

The broad Oligocene passage between the Indian and Pacific Oceans must have enabled significant surface and intermediate water exchange and the possibility of deepwater flow from the Indian Ocean to the Pacific Ocean (Thomas et al., 2003). The progressive closure of the Indonesian Gateway caused by the northward movement of Australia (Hall, 2002; Hall et al., 2011; Kuhnt et al., 2004) induced changes in deepwater and intermediate water circulation through the Indonesian Gateway, which may have resulted in a significant change in the Eastern Indian Ocean neodymium $(\mathrm{Nd})$ isotope composition during the middle Miocene (Frank et al., 2006; Gourlan et al., 2008). A second shift in Eastern Indian Ocean Nd 
isotopes may have been related to a shift in the source area of the Indonesian Throughflow toward the North Pacific around 3.5 Ma (Cane and Molnar, 2001; Gourlan et al., 2008).

\section{Geological setting}

The eastern continental margin of India is the result of the separation of India and the Australia/Antarctica portion of Gondwanaland during the Early Cretaceous at 130 Ma (Powell et al., 1988; Scotese et al., 1988). The $2000 \mathrm{~m}$ isobaths of the northeast Indian continental margin and the East Antarctica margin (Prydz Bay) are closely matched, supporting the inferred alignment of India and Antarctica prior to rifting (Subrahmanyam et al., 2008). The major Indian peninsular rivers draining into the Bay of Bengal (Figure F6) are thought to be associated with graben features resulting from the rifting of India from Antarctica as well as subsequent Indian plate motion. The Mahanadi Graben, for example, appears to have a con-

Figure F6. Main river basins draining into the Bay of Bengal and Andaman Sea. Map was generated using GeoMapApp (http://www.geomapapp.org), using topography and bathymetry from the Global Multi-Resolution Topography synthesis (Ryan et al., 2009).

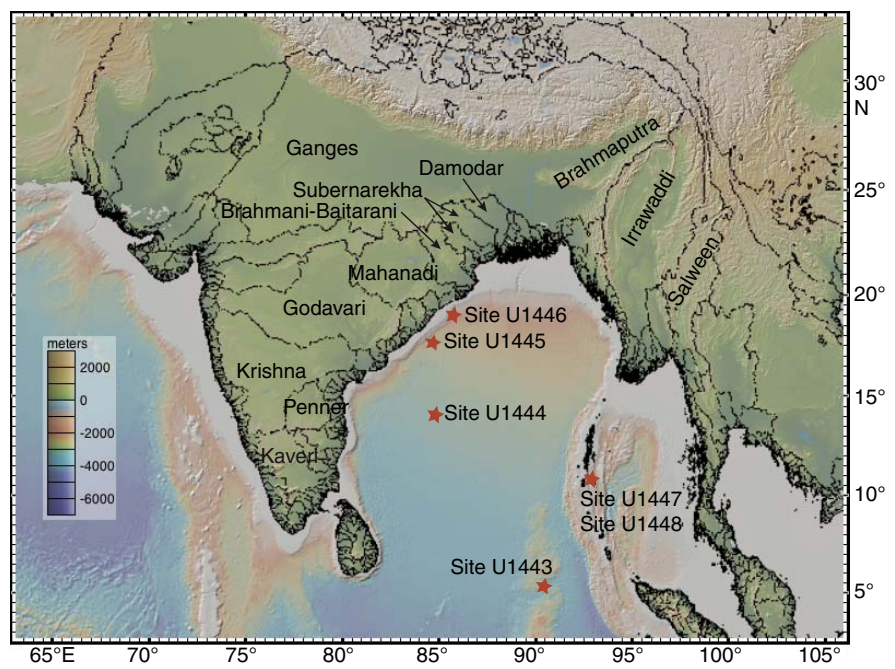

tinuation in Prydz Bay, Antarctica, known as Lambert Graben (Federov et al., 1982).

The Ninetyeast Ridge (NER) is an aseismic volcanic ridge spanning $\sim 31^{\circ} \mathrm{S}$ to $\sim 10^{\circ} \mathrm{N}$, where it is buried beneath Bengal Fan sediments. The NER is thought to have formed by age-progressive hotspot volcanism from plume sources currently beneath the Kerguelen Plateau (Royer et al., 1991; Sager et al., 2010). The ridge top rises to a height of $\sim 3.5 \mathrm{~km}$ above the surrounding abyssal plain with depths as shallow as $\sim 2000$ meters below sea level (mbsl). Site $\mathrm{U} 1443$ is located at $\sim 5^{\circ} \mathrm{N}$ at $2925 \mathrm{mbsl}$. This location provides good preservation of carbonate microfossils given that the foraminiferal lysocline in this region is close to $3300 \mathrm{mbsl}$ (Cullen and Prell, 1984).

The Andaman Sea is situated between the Andaman Islands and the Malaya Peninsula (Figure F2). The Andaman-Sumatra island arc system results from oblique subduction of the Indo-Australian plate beneath the Eurasian plate (Singh et al., 2013). Stretching and rifting of the overriding plate in the early Miocene $(\sim 25 \mathrm{Ma})$ has resulted in two distinct plates (Sunda and Burma) separated by an active spreading center (Curray, 1991) located in the deepest portion of the Andaman Sea. An accretionary wedge complex, scraped off the subducting slab, lies west of the spreading center, forming a series of shallower basins associated with backthrust faulting within the accreted sediments (Figure F7). The Andaman Sea drilling sites are within the western part of the Andaman forearc basin (west of the Nicobar-Andaman Basin), bounded on either side by the Diligent and Eastern Margin faults. Terrigenous sediment supply to the Andaman Sea originates dominantly from the Irrawaddy and Salween Rivers (Colin et al., 1998; Ali et al., 2015). Analysis of Andaman Sea surface sediments indicates that foraminifers are abundant and well preserved shallower than $\sim 1800 \mathrm{mbsl}$ ( $>100,000$ individuals/gram) and decrease to $<100$ individuals/gram deeper than $3000 \mathrm{mbsl}$ (Frerichs, 1971).

\section{Modern atmospheric and oceanographic circulation}

The Indian summer monsoon is characterized by low atmospheric pressure over the Indo-Asian continent (Indo-Asian Low) relative to high atmospheric pressure over the southern subtropical Indian Ocean (Mascarene High). The resulting pressure gradient

Figure F7. Summary sketch after Singh et al. (2013) showing the subduction zone through the back-arc basin to $40 \mathrm{~km}$ depth. EMF = Eastern Margin fault, DF $=$ Diligent fault, $\mathrm{NAB}=$ Nicobar Andaman Basin, ANF = Andaman-Nicobar fault.

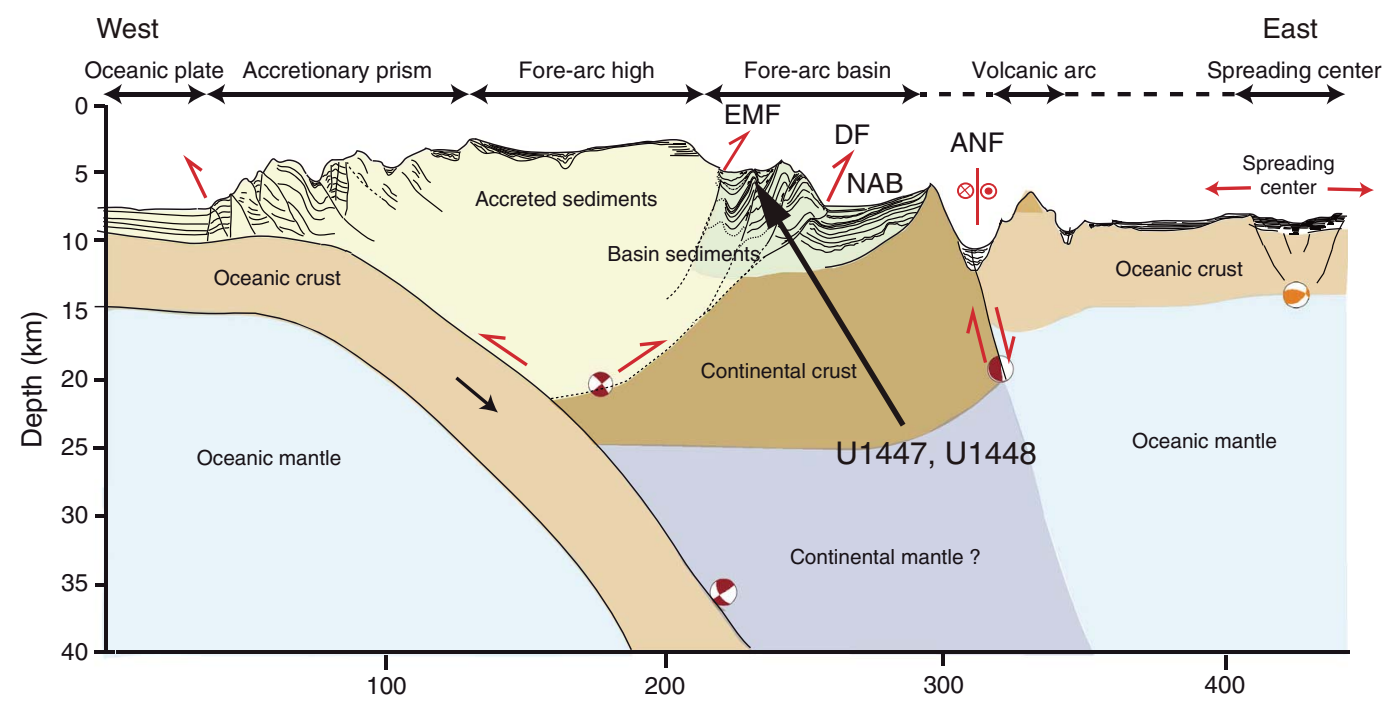


leads to large-scale displacement of the Intertropical Convergence Zone and cross-equatorial flow of low-level winds carrying moisture that is ultimately released over South Asia, the Bay of Bengal, and southeast China (Hastenrath and Greischar, 1993; Liu et al., 1994; Loschnigg and Webster, 2000; Webster, 1987a, 1987b, 1994; Webster et al., 1998). Modern meteorological observations and moisture transport budgets (Figure F8) quantitatively show that the Southern Hemisphere Indian Ocean is the dominant source of moisture (latent heat) to the Indian and East Asian summer monsoons during June, July, and August (JJA) (Bosilovich and Schubert, 2002; Ding and Chan, 2005; Ding et al., 2004; Emile-Geay et al., 2003; Liu and Tang, 2004, 2005; Park et al., 2007; Simmonds et al., 1999; Wajsowicz and Schopf, 2001; Xie and Arkin, 1997; Zhu and Newell, 1998). The Arabian Sea is a very minor moisture source (evaporation > precipitation), whereas the Bay of Bengal/Andaman Sea, India, the South China Sea, and southeast China are all moisture sinks (precipitation > evaporation) (Figure F8).

A total of 12 major rivers feed the Bay of Bengal/Andaman Sea (Ganges, Brahmaputra, Meghna, Damodar, Mahanadi, Godavari, Krishna, Irrawaddy, Salween, Penner, Kavery, and Mahaweli Rivers) (Figure F6), discharging in total $943 \times 10^{9} \mathrm{~m}^{3}$ of water during the summer monsoon months (JJA) (Varkey et al., 1996), accounting for $\sim 50 \%$ of the total freshwater input, the remaining being from direct precipitation (Akhil et al., 2014). Annual rainfall within and surrounding the Bay of Bengal is dominated by precipitation during JJA with the exception of the Chennai Basin in southernmost peninsular India, where rainfall peaks in November (Figure F9). The dominance of the JJA precipitation signal is reflected in the Bay of Bengal surface salinity patterns (Figure F4), spanning salinities of 20-34 over both seasonal (summer-winter) and spatial (north-south) scales, with lowest values in August and September.

Primary surface ocean currents (Schott and McCreary, 2001; Schott et al., 2009) reflect the seasonal wind forcing in both the eastern Arabian Sea and the Bay of Bengal (Figure F10). The West Indian Coastal Current (WICC) flows south during the summer monsoon, connecting with the Southwest Monsoon Current (SMC) that carries high-salinity waters eastward around the tip of India and Sri Lanka into the southern Bay of Bengal at a rate of 8.4 Sver$\operatorname{drup}\left(\mathrm{Sv}=10^{6} \mathrm{~m}^{3} / \mathrm{s}\right)$. This influx of high-salinity water is reflected in the southern Bay of Bengal July, August, and September salinity patterns (Figure F4) and is successfully modeled as a passive tracer in mixed-layer ocean models (Jensen, 2001, 2003). Southwest summer monsoon winds in the Bay of Bengal also drive the northward-flowing East Indian Coastal Current (EICC). During the winter monsoon, northeast winds drive all these surface currents in the opposite directions, transporting $11 \mathrm{~Sv}$ of water toward the eastern Arabian Sea.

Salinity on the Indian margin, northwest Bay of Bengal, reaches a minimum of $\sim 22$ in September (Figure F4); this is a lagged response to JJA rainfall over the Bay of Bengal and the surrounding drainage basins as well as seasonal surface current patterns. Salinity at this location reaches a maximum of 34 during the spring months. The Andaman Sea sites, situated between the modern 32 and 33 annual average isohalines, monitor drainage from the Irrawaddy and Salween Rivers. Salinity in the southern Bay of Bengal (Site U1443) is closely pinned to the 34 isohaline year round, anchoring the southern end of the modern salinity gradient at near open-ocean values. Although this site does not currently experience significant seasonal salinity variability, it does record large-scale changes in precipitation and runoff at the millennial, orbital, glacial-interglacial, and tectonic scales as discussed below. The full meridional transect (spanning the Indian margin, Andaman Sea, and northern NER) has a modern salinity range of 12 .

Estimates for expected $\delta^{18} \mathrm{O}_{\text {G.ruber }}$ values can be calculated by combining climatologies for monthly temperature and salinity with regional $\delta^{18} \mathrm{O}_{\text {seawater }}$-salinity equations (Figure F11). Northern $\left(20^{\circ} \mathrm{N}\right) \delta^{18} \mathrm{O}_{\text {G.ruber }}$ estimates range between $-1.9 \%$ for January and $-3.3 \%$ for October with strong sensitivity to salinity seasonality. Estimates for $5^{\circ} \mathrm{N}$ range from $-2.5 \%$ o (August-December) to $-2.9 \%$ (April) with strong sensitivity to temperature seasonality.

Terrestrial runoff products are also of significant utility in assessing linkages between monsoon circulation, chemical weather-

Figure F8. Summer monsoon moisture budget and transport path (inset) after Ding et al. (2004). Moisture budget averaged for 1990-1999 (June, July, and August; units are $10^{6} \mathrm{~kg} / \mathrm{s}$ ). The southern Indian Ocean is the dominant moisture (latent heat) source. The Bay of Bengal, Indochina, the South China Sea, and China are all moisture sinks. No significant Pacific moisture source is indicated. Summer monsoon moisture transport patterns (inset) averaged for $1990-1999$ (the 5 th pentad of May through the 2 nd pentad of July; units are $\mathrm{kg} / \mathrm{m} / \mathrm{s}$ ).

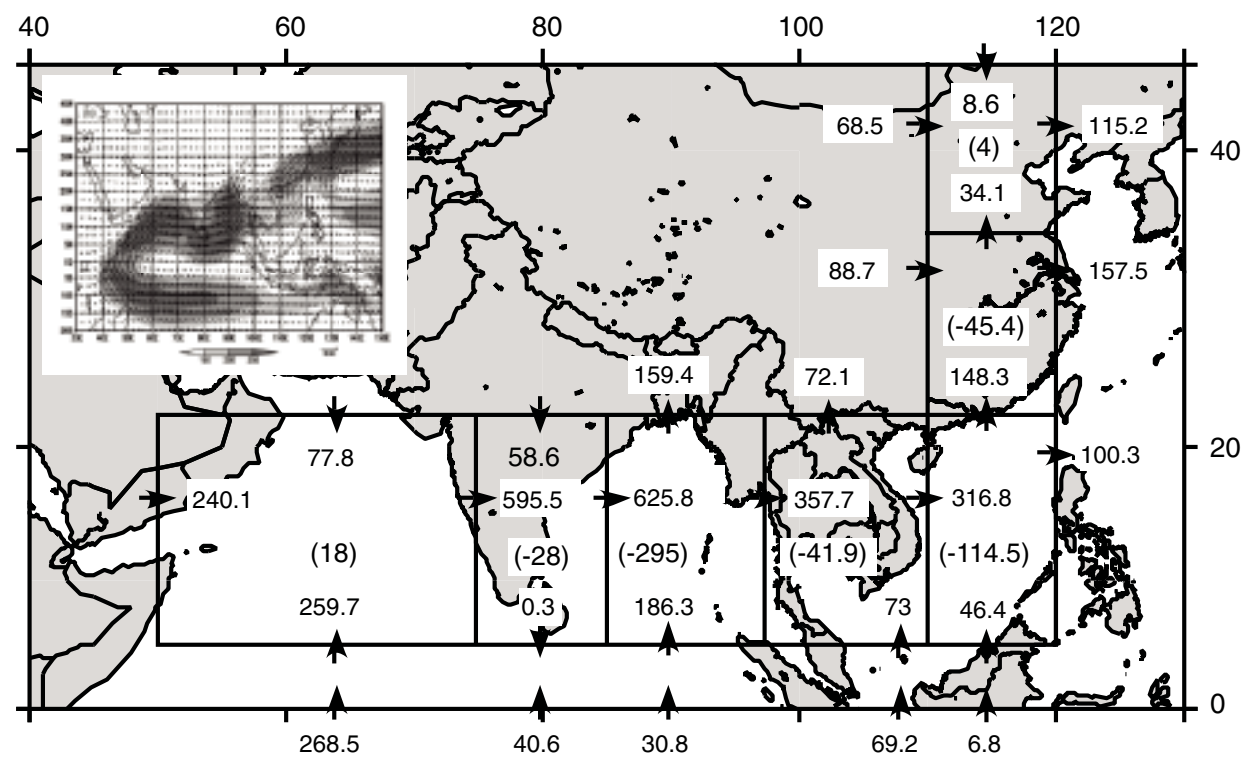


Figure F9. Monthly precipitation data for 1948-2011 (as available) for locations with drainage into the Bay of Bengal. Cherrapunji precipitation is scaled separately. Data from World Meteorological Organization (http://climexp.knmi.nl).

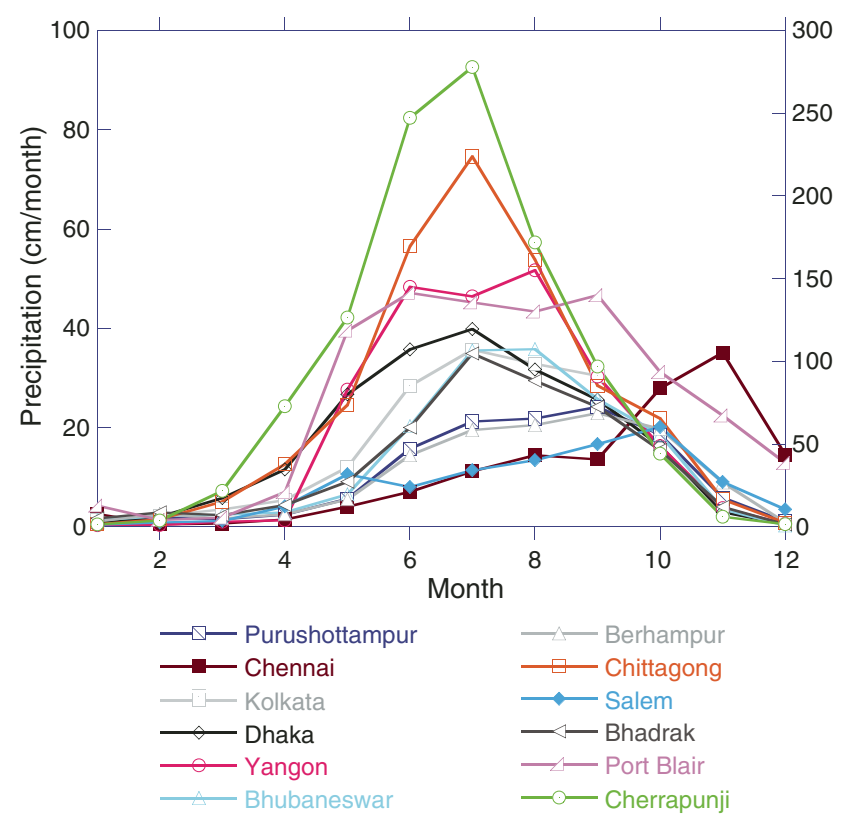

ing, and transport at timescales from millennial to tectonic (Clift and Plumb, 2008; Wang et al., 2005). Changes in monsoon strength are well documented at $\sim 23,15,8-7$, and $2.75 \mathrm{Ma}$ (Clift and Plumb, 2008). The Expedition 353 drilling targets will allow measurement of the consequent impact on weathering rates and transport of particulate materials to the ocean basins in a variety of settings both proximal and distal relative to river inputs.

\section{Water masses and deep circulation}

Comprehensive descriptions of eastern Indian Ocean regional oceanography are provided in Wyrtki (1971), Mantyla and Reid (1995), Tomczak and Godfrey (2003), and Schott et al. (2009), from which we briefly summarize descriptions of water masses and circulation patterns relevant for Bay of Bengal drilling in the depth range between 1100 and $3000 \mathrm{~m}$ targeted for Expedition 353.

Indian Deep Water (IDW) occupies the depth range from 3800 to $\sim 1500 \mathrm{~m}$ within the equatorial and northern Indian Ocean (Figure F12). IDW in the eastern Indian Ocean is characterized by high salinities, reaching maxima of 34.8 in the southwestern Indian Ocean and 34.75 in the southeastern Indian Ocean, where the IDW upper limit rises to $500 \mathrm{~m}$ (Tomczak and Godfrey, 2003). IDW temperature, salinity, and oxygen properties in the high-salinity core are virtually identical with those of North Atlantic Deep Water (NADW) in the Atlantic sector of the Southern Ocean, indicating that IDW is mainly of NADW origin and not originally formed in the Southern Ocean, as is the Antarctic Bottom Water (AABW) that occupies the Indian Ocean deeper than $3800 \mathrm{~m}$ (Tomczak and Godfrey, 2003). The flow of IDW is northward and concentrated along the African margin and the NER as indicated by the World Ocean Circulation Experiment (WOCE) $95^{\circ} \mathrm{E}$ oxygen, silicate, and temperature profiles (Figure F13). IDW further penetrates northward into the Northern Hemisphere, is modified by mixing with thermocline water from above and upwelling of AABW from below, and spreads into the Arabian Sea and the Bay of Bengal.
Figure F10. World Ocean Atlas Monthly Mean Temperature $\left({ }^{\circ} \mathrm{C}\right)$ for $1955-$ 2006 (Locarnini et al., 2010). Summer and winter monsoon current systems follow Schott and McCreary (2001). Site locations in the Andaman Sea (Sites U1447 and U1448), Mahanadi basin, Bay of Bengal (Sites U1445 and U1446), and Site U1443 (redrill ODP Site 758) are shown. WMC = Winter Monsoon Current.
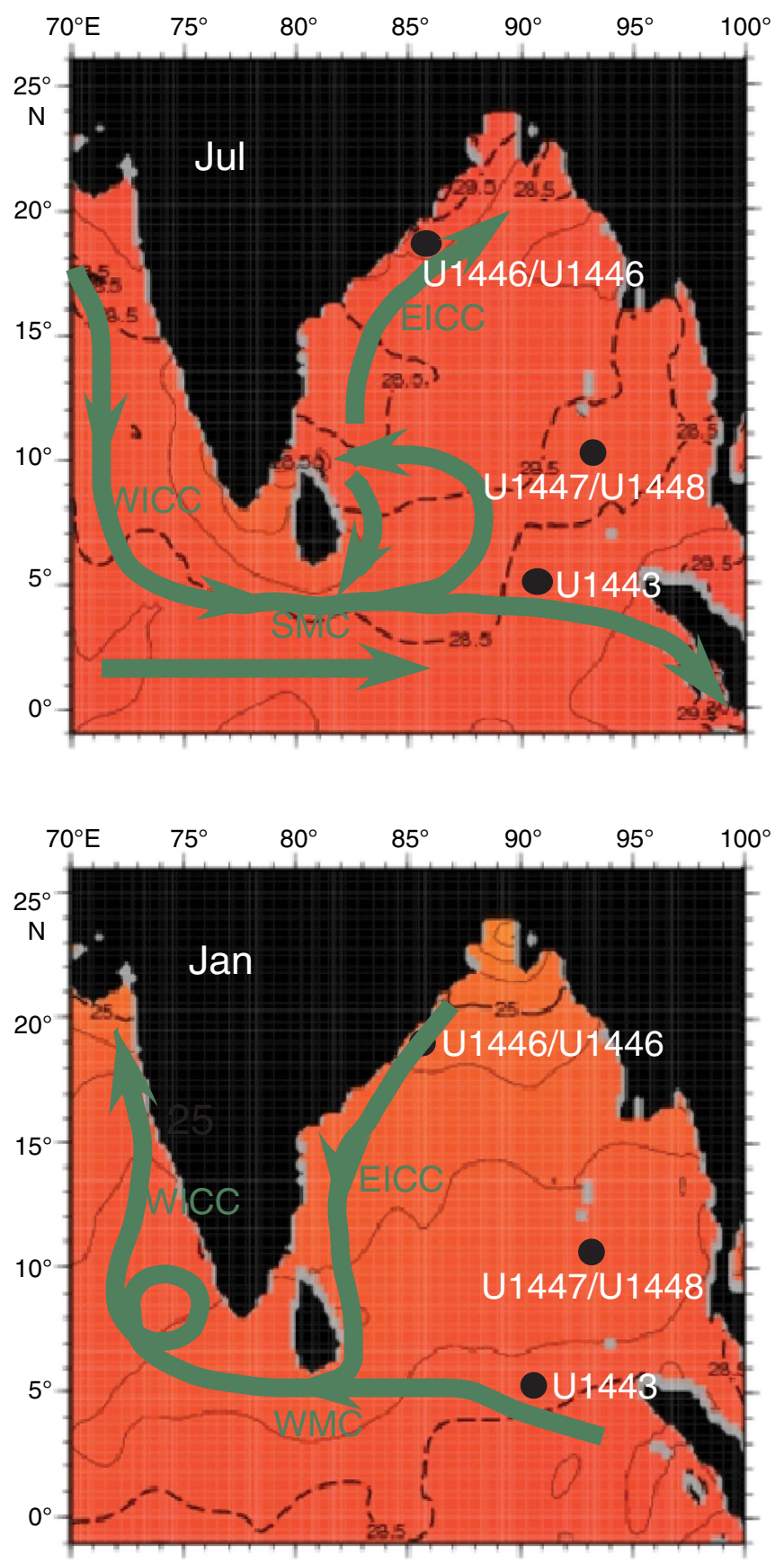

Two water masses occupy the thermocline of the Indian Ocean, Indian Central Water (ICW) and Indonesian Throughflow Water (ITW) or Australasian Mediterranean Water (Figure F14). ICW originates from downwelling in the subtropical convergence south of $30^{\circ} \mathrm{S}$, and ITW is derived from North Pacific Intermediate Water, strongly modified during its passage through the Indonesian archipelago. There is no formation of thermocline water in the Bay of 
Figure F11. Estimated monthly G. ruber $\delta^{18} \mathrm{O}$ derived from monthly salinity and temperature climatologies at (A) $5^{\circ} \mathrm{N}, 90^{\circ} \mathrm{E}$ and (B) $20^{\circ} \mathrm{N}, 86^{\circ} \mathrm{E}, \mathrm{Bay}$ of Bengal. Monthly mean $\pm 1 \sigma$ over 1958-2013. Sea-surface temperature (SST) from HadISST data set (Rayner et al., 2003). Sea-surface salinity (SSS) from ORA-S4 data set (Balmaseda et al., 2012). Pseudo- $\delta 18 \mathrm{O}$ of $G$. ruber (white) constructed from SST and SSS data set using low-light equation of Bemis et al. (1998) and open-ocean

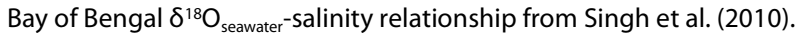
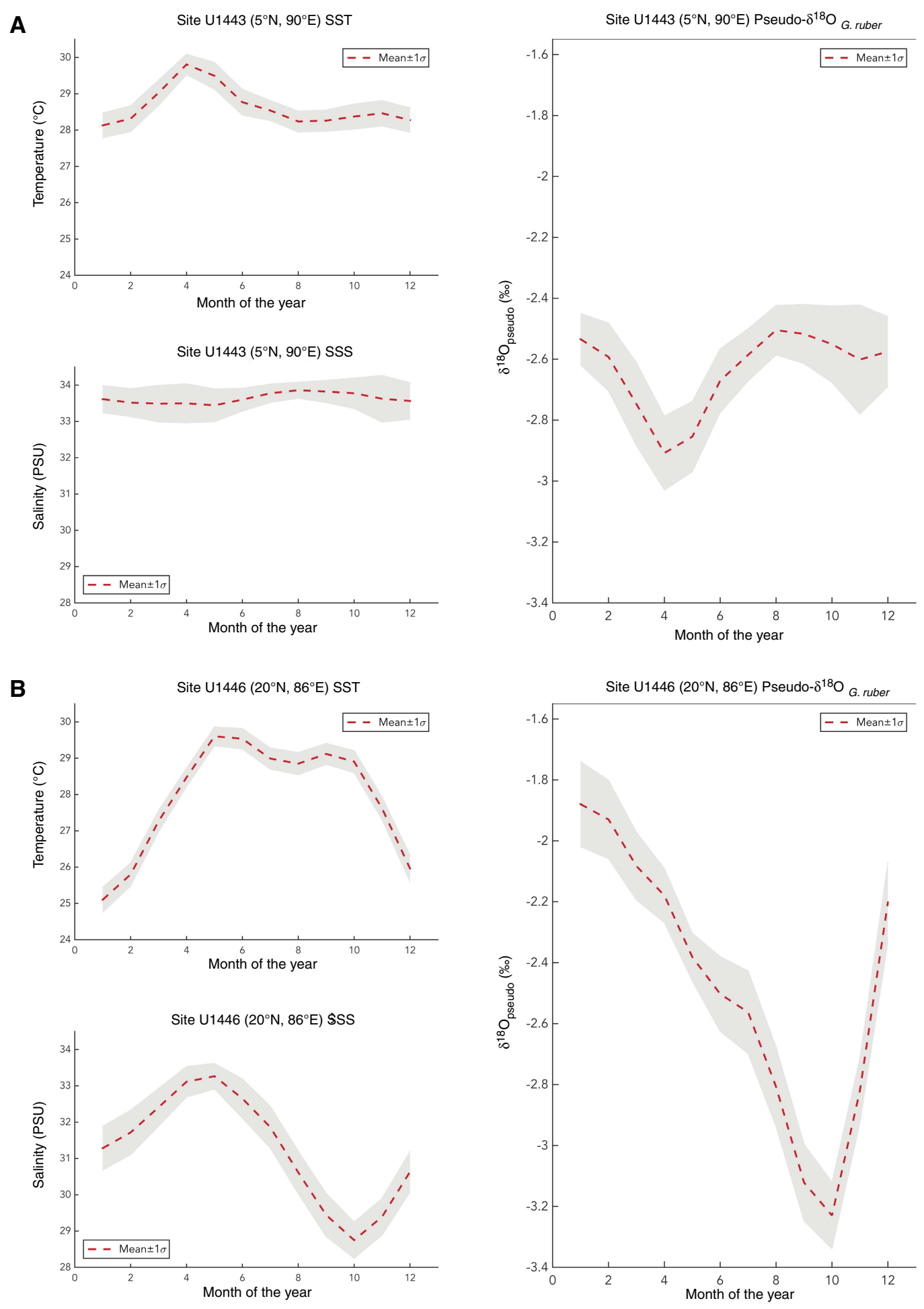

Bengal, and its thermocline water masses to $1500 \mathrm{~m}$ water depth are derived from ICW and ITW. Transfer of ICW to the northern Indian Ocean is accompanied by a rapid decrease in oxygen content, indicating aging along the path. The lowest oxygen values occur in the Bay of Bengal, which contains the oldest ICW. The strong oxy-

gen decrease in the northern Indian Ocean can be explained by reduction of the transfer of ICW during the southwest monsoon season, resulting in a small annual net transfer rate. ITW also contributes to the renewal of thermocline water in the northern Indian Ocean, resulting in significant freshening of the ICW along its path 
Figure F12. Indian Ocean deep and bottom water circulation (from Frank et al., 2006). Blue arrows represent the deep and bottom water flow patterns in the Indian Ocean. After Mantyla and Reid (1995).

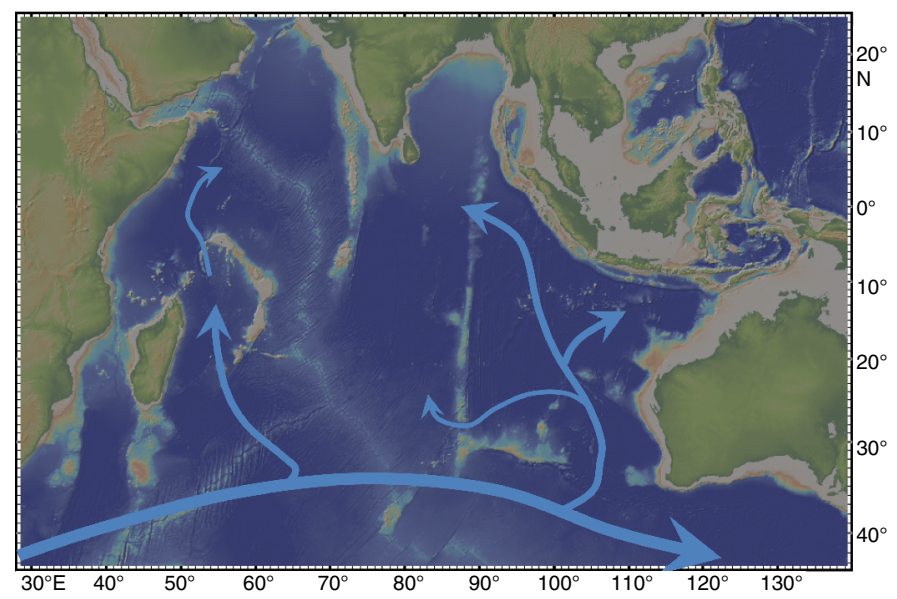

Figure F13. Salinity, silicate, and oxygen from eastern Indian Ocean WOCE meridional Transect 109, eastern Indian Ocean (from eWOCE Gallery, http://www.ewoce.org/gallery [Schlitzer, 2000]).
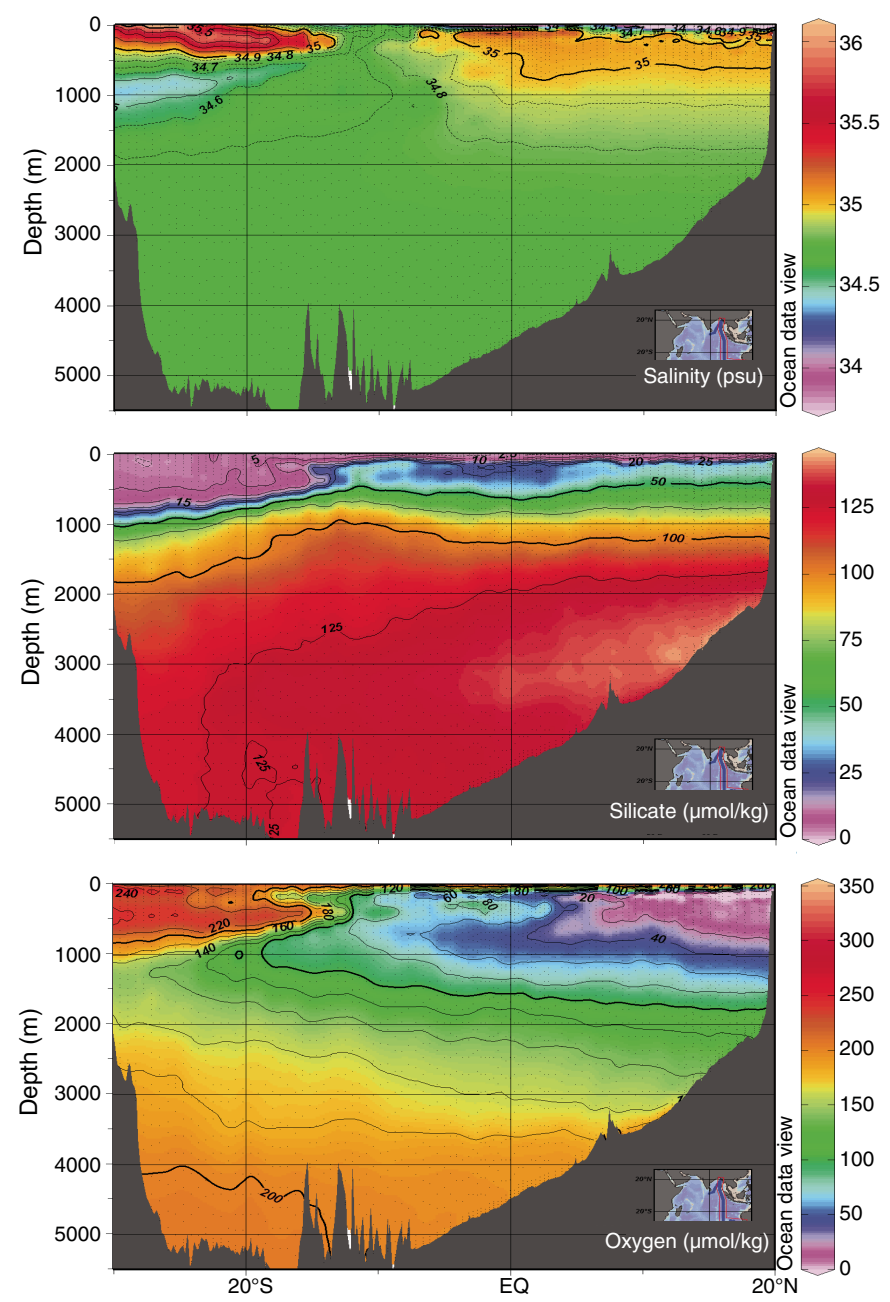

Figure F14. Mean (A) temperature and (B) salinity in the upper thermocline on isopycnal Surface 25.7, located in the depth range 150-200 m (after You and Tomczak, 1993). Arrows indicate movement of Indian Central Water (black) and Indonesian Throughflow Water (red). From Xu et al. (2006).

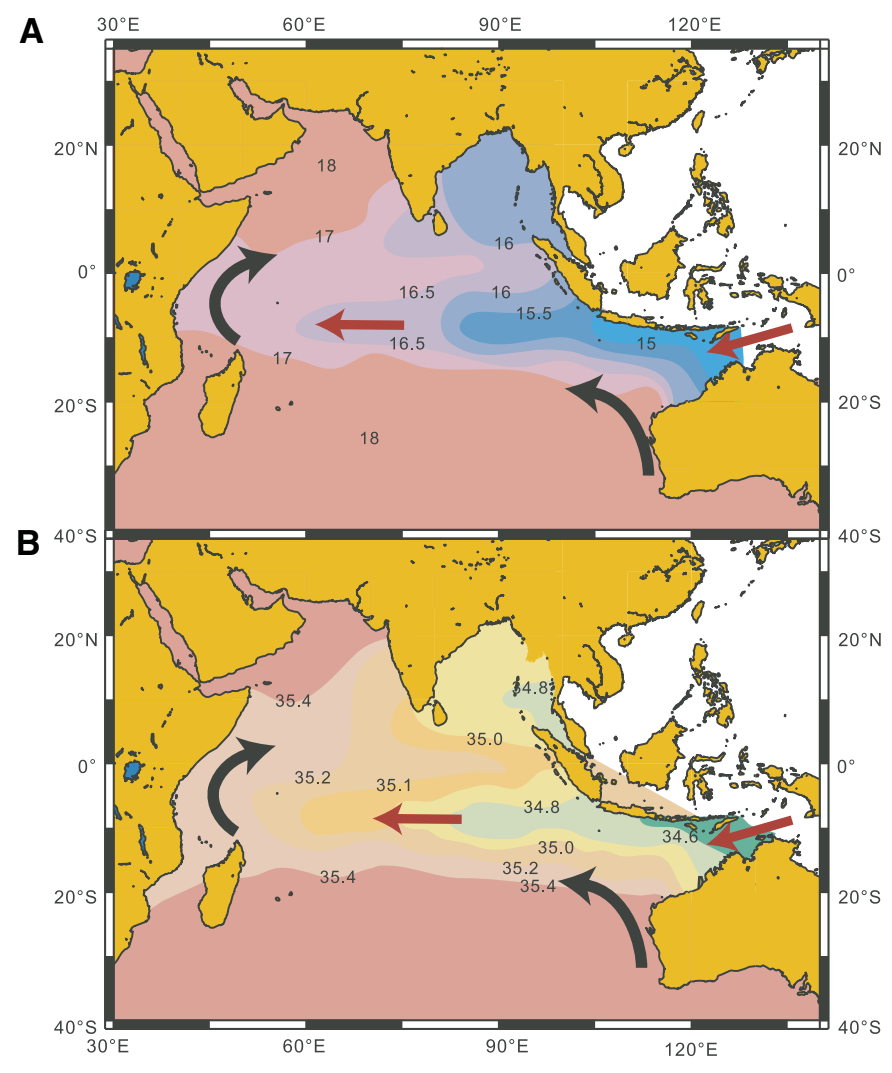

into the Bay of Bengal. Further freshening is observed in the Bay of Bengal near $90^{\circ} \mathrm{E}$, resulting from ITW advection directly from its outflow area into the tropical eastern Indian Ocean. Variability and evolution of thermocline circulation in the Bay of Bengal are strongly dependent on monsoonal forcing; however, the present extremely low oxygen levels indicate a very low renewal rate for the thermocline waters of the Bay of Bengal.

The uppermost $100 \mathrm{~m}$ of the eastern Indian Ocean in the Bay of Bengal consists of a low-salinity water mass derived from river runoff from India and Indochina, the Bay of Bengal Water (BBW), with surface salinity strongly fluctuating with seasons but remaining below 33 throughout the year. The lower boundary to the ICW is characterized by a strong halocline. The southward extension of the $\mathrm{BBW}$ surface water mass is highest during October-December when it reaches the area along the western Indian coast and is lowest during April-June before the summer monsoon leads to a new expansion of the BBW.

\section{Site summaries}

\section{Site U1443}

\section{Background and objectives}

The NER represents the trace of the Kerguelen/Ninetyeast hotspot prior to middle Eocene rifting (Peirce, Weissel, et al., 1989). As a result of northward movement, Site U1443 moved from tem- 
perate southern latitudes during the Campanian to $\sim 5^{\circ} \mathrm{S}$ near the Oligocene/Miocene boundary and to its present $5^{\circ} \mathrm{N}$ location in the southernmost Bay of Bengal (Figure F2). The site has been within $10^{\circ}$ of the Equator for the past 35 My (Shipboard Scientific Party, 1989). The ridge-top location ( $2925 \mathrm{mbsl}$ ) has prevented the deposition of sedimentary sequences typically associated with fan transport processes and is thus a useful location for recovery of openocean pelagic sediments.

Site U1443 is located $\sim 100 \mathrm{~m}$ southeast of ODP Site 758 on the crest of the NER (Figure F2; Table T1). Previous drilling at this site included overlapping holes (758A and 758B) only for the uppermost $92 \mathrm{~m}$ of the total $527 \mathrm{~m}$ of sediments drilled. This limited the resulting composite record to the past 7.3 My (Farrell and Janecek, 1991).

In spite of these limitations, the IODP sample database shows that more than 16,000 sediment samples have been taken from Site 758 cores in the last $10 \mathrm{y}$. Parts of the uppermost sections are almost entirely depleted, and sampling has moved to the archive half. Recent research using Site 758 sediments include high-resolution (suborbital) Late Pleistocene reconstruction of changes in upper water column structure based on multispecies planktonic foraminifer records (Bolton et al., 2013), reconstruction of the Li isotope composition of seawater over the past $70 \mathrm{My}$ (Misra and Froelich, 2012), Late Cretaceous to early Eocene reconstruction of seawater neodymium (Le Houedec et al., 2012), and glacial-interglacial scale reconstruction of Os isotopic composition of seawater (Burton et al., 2010). Drilling Site U1443 had the following main objectives:

- Establish a composite section for the entire Miocene-Oligocene sedimentary succession at the NER, which would be the basis for establishing the first orbitally tuned Indian Ocean isotope stratigraphy for this time interval.
- Recover a more complete record of the Cretaceous/Paleogene boundary interval, which was only incompletely retrieved at the base of the core catcher of Core 121-758A-31X.

- Correlate the onset of increased terrigenous clay component and sedimentation rates in the late Miocene to orbitally tuned isotope and magnetic reversal stratigraphy.

- Precisely determine the timing of intensifications of the Indian monsoon, as evident from increased freshwater input to the Bay of Bengal and northern end of the NER using salinity proxies based on $\mathrm{Mg} / \mathrm{Ca}$-temperature estimates and $\delta^{18} \mathrm{O}$ of surfacedwelling planktonic foraminifers.

- Investigate variability and possible influence of orbital forcing on fluxes of terrigenous material to the northern NER since the middle Miocene. In particular, relate terrigenous pulses at $~ 7.0-$ 5.6 and $\sim 3.9-2.0 \mathrm{Ma}$, which were interpreted to represent variations in the fluvial flux resulting from the uplift and erosion of the Himalaya (Hovan and Rea, 1992), to the variability of the Indian monsoon.

- Extend the Pliocene-Pleistocene stable isotope record for Site 758 , which is the only "high-resolution" record across the initiation of Northern Hemisphere glaciation in the Indian Ocean (Hoogakker et al., 2006; Mudelsee and Raymo, 2005), into the Miocene and Oligocene.

- Use the Nd isotope composition of NER sediments to extend reconstructions of the relative contribution of suspended sediment from the Ganges-Brahmaputra, Irrawaddy, Arakan, and Indian peninsular rivers as indicators of glacial-interglacial variability in monsoon strength into the Miocene (Burton and Vance, 2000; Stoll et al., 2007; Gourlan et al., 2008, 2010). A complete Neogene sediment archive at Site U1443 opens the possibility to obtaining proxy records for river discharge in suffi-

Table T1. Expedition 353 hole summary. Download table in .csv format.

\begin{tabular}{|c|c|c|c|c|c|c|c|c|c|c|c|c|c|}
\hline Site & Hole & Latitude & Longitude & $\begin{array}{l}\text { Seafloor } \\
\text { depth } \\
\text { (mbrf) }\end{array}$ & Cores $(N)$ & Cored $(\mathrm{m})$ & $\begin{array}{l}\text { Recovered } \\
(\mathrm{m})\end{array}$ & $\begin{array}{l}\text { Recovery } \\
\text { (\%) }\end{array}$ & $\begin{array}{l}\text { Drilled } \\
(\mathrm{m})\end{array}$ & $\begin{array}{c}\text { Total } \\
\text { penetration } \\
(\mathrm{m})\end{array}$ & $\begin{array}{l}\text { Total depth } \\
\text { (mbrf) }\end{array}$ & $\begin{array}{l}\text { Time on } \\
\text { hole }(\mathrm{h})\end{array}$ & $\begin{array}{l}\text { Time on site } \\
\text { (days) }\end{array}$ \\
\hline U1443 & $A$ & $5^{\circ} 23.0098^{\prime} \mathrm{N}$ & $90^{\circ} 21.7100^{\prime} \mathrm{E}$ & 2940.2 & 48 & 344.00 & 326.80 & 95 & 0.0 & 344.0 & 3284.2 & 77.50 & \\
\hline U1443 & $\mathrm{B}$ & $5^{\circ} 23.0190^{\prime} \mathrm{N}$ & $90^{\circ} 21.7091^{\prime} \mathrm{E}$ & 2935.5 & 40 & 326.40 & 308.51 & 95 & 0.0 & 326.4 & 3261.9 & 44.75 & \\
\hline U1443 & $\mathrm{C}$ & $5^{\circ} 23.0078^{\prime} \mathrm{N}$ & $90^{\circ} 21.6984^{\prime} \mathrm{E}$ & 2935.4 & 28 & 207.90 & 182.87 & 88 & 1.5 & 209.4 & 3144.8 & 38.00 & \\
\hline \multirow[t]{2}{*}{ U1443 } & $\mathrm{D}$ & $5^{\circ} 22.9991^{\prime} \mathrm{N}$ & $90^{\circ} 21.6992^{\prime} \mathrm{E}$ & 2935.3 & 2 & 8.20 & 7.48 & 91 & 0.0 & 8.2 & 2943.5 & 12.25 & \\
\hline & & & \multicolumn{2}{|c|}{ Site U1443 totals: } & 118 & 886.50 & 825.66 & 93 & 1.5 & 888.0 & & & 7.12 \\
\hline U1444 & $A$ & $14^{\circ} 00.0057^{\prime} \mathrm{N}$ & $84^{\circ} 49.7405^{\prime} \mathrm{E}$ & 3143.4 & 37 & 330.60 & 226.05 & 68 & 0.0 & 330.6 & 3474.0 & 70.75 & \\
\hline \multirow[t]{2}{*}{ U1444 } & $B$ & $13^{\circ} 59.9940^{\prime} \mathrm{N}$ & $84^{\circ} 49.7412^{\prime} \mathrm{E}$ & 3142.5 & 9 & 81.10 & 74.16 & 91 & 47.5 & 128.6 & 3271.1 & 24.75 & \\
\hline & & & \multicolumn{2}{|c|}{ Site U1444 totals: } & 46 & 411.70 & 300.21 & 73 & 47.5 & 459.2 & & & 4.00 \\
\hline U1445 & $A$ & $17^{\circ} 44.7217^{\prime} \mathrm{N}$ & $84^{\circ} 47.2518^{\prime} \mathrm{E}$ & 2513.1 & 77 & 672.60 & 666.40 & 99 & 0.0 & 672.6 & 3185.7 & 155.50 & \\
\hline U1445 & $\mathrm{B}$ & $17^{\circ} 44.7098^{\prime} \mathrm{N}$ & $84^{\circ} 47.2498^{\prime} \mathrm{E}$ & 2514.5 & 4 & 33.00 & 33.36 & 101 & 0.0 & 33.0 & 2547.5 & 6.00 & \\
\hline \multirow[t]{2}{*}{ U1445 } & $\mathrm{C}$ & $17^{\circ} 44.7095^{\prime} \mathrm{N}$ & $84^{\circ} 47.2387^{\prime} \mathrm{E}$ & 2513.5 & 36 & 305.20 & 305.60 & 100 & 0.0 & 305.2 & 2818.7 & 64.50 & \\
\hline & & & \multicolumn{2}{|c|}{ Site U1445 totals: } & 117 & 1010.80 & 1005.36 & 99 & 0.0 & 1010.8 & & & 9.42 \\
\hline U1446 & $A$ & $19^{\circ} 5.0090^{\prime} \mathrm{N}$ & $85^{\circ} 44.0894^{\prime} \mathrm{E}$ & 1441.2 & 21 & 180.00 & 186.63 & 104 & 0.0 & 180.0 & 1621.2 & 28.75 & \\
\hline U1446 & B & $19^{\circ} 5.0085^{\prime} \mathrm{N}$ & $85^{\circ} 44.0786^{\prime} \mathrm{E}$ & 1440.5 & 3 & 27.10 & 27.20 & 100 & 0.0 & 27.1 & 1467.6 & 2.50 & \\
\hline \multirow[t]{2}{*}{ U1446 } & $\mathrm{C}$ & $19^{\circ} 5.0215^{\prime} \mathrm{N}$ & $85^{\circ} 44.0780^{\prime} \mathrm{E}$ & 1441.1 & 23 & 182.00 & 180.55 & 99 & 0.0 & 182.0 & 1623.1 & 24.50 & \\
\hline & & & \multicolumn{2}{|c|}{ Site U1446 totals: } & 47 & 389.10 & 394.38 & 101 & 0.0 & 389.1 & & & 2.32 \\
\hline U1447 & $A$ & $10^{\circ} 47.4061^{\prime} \mathrm{N}$ & $92^{\circ} 59.9999^{\prime} \mathrm{E}$ & 1402.2 & 88 & 738.00 & 732.96 & 99 & 0.0 & 738.0 & 2140.2 & 122.50 & \\
\hline U1447 & B & $10^{\circ} 47.3945^{\prime} \mathrm{N}$ & $93^{\circ} 00.0028^{\prime} \mathrm{E}$ & 1403.1 & 3 & 24.40 & 24.26 & 99 & 0.0 & 24.4 & 1427.5 & 5.25 & \\
\hline \multirow[t]{2}{*}{ U1447 } & $\mathrm{C}$ & $10^{\circ} 47.3952^{\prime} \mathrm{N}$ & $93^{\circ} 00.0114^{\prime} \mathrm{E}$ & 1403.6 & 17 & 158.90 & 158.32 & 100 & 2.0 & 160.9 & 1564.5 & 19.25 & \\
\hline & & & \multicolumn{2}{|c|}{ Site U1447 totals: } & 108 & 921.30 & 915.54 & 99 & 2.0 & 923.3 & & & 6.13 \\
\hline U1448 & $A$ & $10^{\circ} 38.0315^{\prime} \mathrm{N}$ & $93^{\circ} 00.0036^{\prime} \mathrm{E}$ & 1109.7 & 60 & 421.00 & 434.82 & 103 & 0.0 & 421.0 & 1530.7 & 47.75 & \\
\hline U1448 & B & $10^{\circ} 38.0202^{\prime} \mathrm{N}$ & $93^{\circ} 00.0032^{\prime} \mathrm{E}$ & 1107.9 & 57 & 357.10 & 369.38 & 103 & 1.5 & 358.6 & 1466.5 & 36.00 & \\
\hline \multirow[t]{3}{*}{ U1448 } & $\mathrm{C}$ & $10^{\circ} 38.0830^{\prime} \mathrm{N}$ & $93^{\circ} 00.0233^{\prime} \mathrm{E}$ & 1108.2 & 4 & 34.30 & 34.77 & 101 & 0.0 & 34.3 & 1142.5 & 9.25 & \\
\hline & & & \multirow{2}{*}{\multicolumn{2}{|c|}{$\begin{array}{r}\text { Site U1448 totals: } \\
\text { Expedition } 353 \text { totals: }\end{array}$}} & 121 & 812.40 & 838.97 & 103 & 1.5 & 813.9 & & & 3.90 \\
\hline & & & & & 557 & 4431.8 & 4280.12 & 97 & 52.5 & 4484.3 & & 789.75 & 32.90 \\
\hline
\end{tabular}


cient time resolution to document the relation between global climate and the Indian monsoon throughout the Neogene.

\section{Coring summary}

At Site U1443, Holes U1443A-U1443D were drilled to total depths of 344.0, 326.4, 209.4, and $8.2 \mathrm{~m}$ drilling depth below seafloor (DSF), respectively (Table T1). In Holes U1443A and U1443B, the full-length (9.7 $\mathrm{m}$ long) advanced piston corer (APC), halflength advanced piston corer (HLAPC) (4.7 m long), and extended core barrel (XCB) systems were used. The XCB system was deployed after reaching APC refusal depth. The APC and HLAPC systems were used for Hole U1443C, and only the HLAPC system was used for Hole U1443D. A total of 118 cores were recovered at Site U1443. A total of $444.06 \mathrm{~m}$ of core over a $471.7 \mathrm{~m}$ interval was recovered using the APC system ( $94 \%$ recovery). The HLAPC system was used to core a $156.4 \mathrm{~m}$ interval and $161.25 \mathrm{~m}$ of core was recovered (103\%). The cored interval with the XCB system was $258.4 \mathrm{~m}$ with a recovery of $220.35 \mathrm{~m}$ of core (85\%). The overall recovery percentage for Site U1443 was 93\%.

\section{Lithostratigraphy}

Sediments recovered from Site U1443 reveal a range of pelagic and hemipelagic sediments of Late Pleistocene to Campanian age, comprising four distinct lithostratigraphic units (I-IV):

- Unit I (0-107.80 m core depth below seafloor, Method A [CSF-A]) is composed of Late Pleistocene-late Miocene lightdark gray nannofossil oozes with varying proportions of foraminifers, clay, and volcanic ash.

- Unit II (107.80-242.36 m CSF-A) is composed of pale yellow to white nannofossil ooze and chalk with variable contents of authigenic carbonate and foraminifers that are late Miocene to early Oligocene in age.

- Unit III (242.36-308.68 m CSF-A) is late Paleocene to late Campanian in age and comprises a $66 \mathrm{~m}$ thick package of pale yellow and brown nannofossil chalks with varying proportions of authigenic carbonate and occasional chert and porcellanite as nodules and thin beds.

- In Unit IV, a total of $31 \mathrm{~m}$ (308.68-341.35 m CSF-A), comprising a succession of greenish gray marlstones with glauconite of late Campanian age, was recovered before Hole U1443A was terminated at $344 \mathrm{~m}$ DSF.

Lithostratigraphic units are defined by changes in lithology (as identified by visual core description and smear slide observations), physical properties, and color reflectance $\left(\mathrm{L}^{*}, \mathrm{a}^{*}\right.$, and $\left.\mathrm{b}^{*}\right)$. The observed lithologic differences between the units are primarily the result of varying abundances of nannofossils, clay, and authigenic carbonate, with glauconite influencing the color and magnetic susceptibility (MS) properties in Unit IV. Lithologic descriptions are based primarily on sediments recovered from Hole U1443A, supplemented with observations from Holes U1443B-U1443D.

\section{Biostratigraphy}

Calcareous nannofossils are abundant throughout the section in Hole U1443A, which is Late Pleistocene $(<0.29 \mathrm{Ma})$ to Campanian $(>72.1 \mathrm{Ma})$ in age, with a large unconformity that spans most of the Eocene and the latest Paleocene. Nannofossil assemblages are typically tropical to subtropical and are well preserved in the Pleistocene to late Miocene sections ( 0-110 m CSF-A, lithostratigraphic Unit I). Below this interval, evidence of diagenetic overgrowth of nannofossils becomes apparent. Scanning electron microscope
(SEM) analyses revealed that Emiliania huxleyi $(<0.29 \mathrm{Ma})$ is present in intervals $353-\mathrm{U} 1443 \mathrm{~A}-1 \mathrm{H}-1,0-50 \mathrm{~cm}$, and $353-\mathrm{U} 1443 \mathrm{~B}-1 \mathrm{H}-$ $1,0-10 \mathrm{~cm}$. Cretaceous sediments contain abundant moderately to poorly preserved calcareous nannofossils. The Cretaceous/Paleogene (K/Pg) boundary was identified in Core 353-U1443A-39X but is highly bioturbated and appears to be incomplete.

Planktonic foraminifers are dominant to abundant in Samples 353-U1443A-1H-CC through 43X-CC, which are Pleistocene to Late Cretaceous in age. Abundance decreases from common to few in Samples 44X-CC through 48X-CC. Preservation is good to moderate throughout the Cenozoic with a few exceptions in the late Miocene (Sample 13H-CC) and the Oligocene to Paleocene (Samples $33 \mathrm{X}-\mathrm{CC}$ and $34 \mathrm{X}-\mathrm{CC}$ ), where preservation is poor. The latest Maastrichtian is identified in Sample 39X-CC by the presence of Abathomphalus mayaroensis. A low-diversity assemblage characterizes sediments in older samples. Preservation in the Late Cretaceous (Samples 39X-CC through 48X-CC) is moderate to poor.

At Site U1443, diatoms are most abundant from 0 to $28 \mathrm{~m}$ CSF-A; their occurrence then becomes sporadic downcore until 192 $\mathrm{m}$ CSF-A. The diatom assemblage in the uppermost $28 \mathrm{~m}$ of Site U1443 is diverse and mainly consists of Pleistocene to Holocene species, mostly typical of warm to temperate low-latitude ocean waters, and includes species indicating transport of coastal waters to Site U1443.

The age-depth relationship for Hole U1443A is based on the biostratigraphy of the three fossil groups studied (calcareous nannofossils, planktonic foraminifers, and diatoms) and paleomagnetic stratigraphy. Age datums of the fossil groups and paleomagnetism show good agreement for the Pleistocene. Calcareous nannofossils and planktonic foraminifers show consistent age-depth relationships throughout the Cenozoic and Late Cretaceous, with no major outliers. The combined biostratigraphic and paleomagnetic age model indicates a mean sedimentation rate of $1.20 \mathrm{~cm} / \mathrm{ky}$ in the upper part of lithostratigraphic Unit I (0-80 m CSF-A, Pleistocene to late Miocene). The mean sedimentation rate decreases to around $0.41 \mathrm{~cm} / \mathrm{ky}$ between 100 and $130 \mathrm{~m}$ CSF-A (the upper part of lithostratigraphic Subunit IIa, late Miocene to middle Miocene). Sedimentation rates between 135 and $200 \mathrm{~m}$ CSF-A (the lower half of lithostratigraphic Subunit IIa) average $0.81 \mathrm{~cm} / \mathrm{ky}$ (early Miocene to Oligocene). Finally, following a hiatus that spans the late Oligocene to late Paleocene, the mean sedimentation rate in the late Paleocene and Late Cretaceous (lithostratigraphic Units III and IV) is 0.36 $\mathrm{cm} / \mathrm{ky}$. These sedimentation rate and age estimates broadly agree with those published for Site 758 (Shipboard Scientific Party, 1989).

\section{Geochemistry}

The composition of the interstitial water (IW) and bulk sediment samples reflects the variation in sediment composition and reactions that occurred since deposition. Overall, the sediments have high carbonate content ( $>80 \mathrm{wt} \%$ throughout most of the section) and low total organic carbon $(<0.3 \mathrm{wt} \%)$. The depositional environment changed as the site migrated from the Southern Hemisphere to the current location, as the collision of India with Asia delivered more and more terrigenous material to the location. In the upper sediments, ash deposition from the nearby Indonesian arc plays an important role. In general, the data from Site U1443 agree well with data from Site 758, but the new data provide a better resolution in the sections recovered by APC and HLAPC coring compared to the same depth intervals recovered by XCB coring at Site 758. 


\section{Paleomagnetism}

Paleomagnetic measurements were conducted on all archivehalf sections and 127 discrete samples taken from Holes U1443AU1443C. Some of the discrete samples were also subjected to rock magnetic analyses. Magnetic polarity patterns were recovered for most of the APC and HLAPC cores but not for the XCB cores. The resulting magnetostratigraphy was constructed for two time periods: 0-6 Ma (Holes U1443A and U1443C) and 18-25 Ma (Hole U1443A). The age-depth model from paleomagnetic measurements agrees well with the biostratigraphic ages. Between these age intervals, patterns based on pass-through magnetic measurements are inconclusive because of a decrease in natural remanent magnetization (NRM) intensity. An increase in carbonate content and a decrease in the concentration of fine-grained ferrimagnetic minerals explain the poor signal. Preliminary rock magnetic experiments suggest that changes in bulk magnetic properties are primarily controlled by variations in the concentration of fine-grained magnetite/maghemite.

\section{Physical properties}

Downhole variations in physical property measurements at Site U1443 reflect changes in lithology, condensed sections associated with depositional hiatuses, and diagenetic processes. The overall suite of physical property data from Hole U1443A, which is the deepest hole at this site, is divided into three broad physical property (PP) units (1-3) based on significant transitions within the data. The general porosity trend decreases with depth with a few excursions that tend to align with anomalies in $P$-wave velocity. Unit 1 is characterized by high variability in MS, natural gamma radiation (NGR), $P$-wave velocity, and color reflectance. This unit is interpreted to reflect numerous ash layers intercalated within clayey nannofossil ooze. MS peaks are likely the result of relative increases in iron-bearing minerals within the ash layers, and the color reflectance data display changes between darker ash and lighter nannofossil ooze as well as changes in the clay content of the nannofossil ooze. Unit 2 is characterized by a rapid transition to an overall lighter color (high reflectance), with relatively uniform low NGR and low $P$-wave velocity trends. The sedimentologists identify this unit to be dominantly composed of chalk. There are two anomalous intervals identified within Unit 2 that are based on an increase in density, $P$-wave velocity, and NGR but no corresponding change in color reflectance. Variations in physical properties within Unit 2 are visually undetectable. The physical property anomalies were used to assist in directing sampling for smear slide and SEM analysis, which together provided evidence that the anomalous intervals could be due to high authentic overgrowth and carbonate cementation correlating with strong, positive seismic reflections and biostratigraphically defined depositional hiatuses. Unit 3 is characterized by a rapid transition to darker color (low reflectance) along with higher NGR, MS, and $P$-wave values than in Unit 2 , suggesting a transition to a stronger, more lithified material with a likely increase in magnetic minerals and clays that are likely the result of increased terrigenous input. All three units could also be identified in Hole U1443B. The first two units could also be identified in Hole U1443C.

\section{Stratigraphic correlation}

A composite section and splice to establish a continuous sediment sequence were created using Holes U1443A-U1443D. Correlation and splicing were based on MS, NGR, and reflectance spectroscopy $b^{*}$ data (Figure F15). The MS data proved particularly useful for correlation in the upper $\sim 63 \mathrm{~m}$ core composite depth be- low seafloor (CCSF-A) because several tephra layers coincided with positive MS peaks. NGR and reflectance spectroscopy b* data were used throughout the rest of the records. A continuous splice was created spanning the upper $180 \mathrm{~m}$, approximately tripling the length of time over which a continuous record was achieved for Site 758. This is mostly due to the use of the HLAPC, which greatly extended the length of the piston-cored section.

\section{Highlights}

Pliocene-Pleistocene tephrochronology

The Pliocene to Holocene tephra layers of the northern NER provide a unique record of explosive volcanism derived from the Indonesian island of Sumatra, the northernmost part of the Sunda arc, and the nearest volcanically active region (Dehn et al., 1991). Recovery of a complete succession of tephra layers within a complete splice with a high-resolution orbitally tuned isotope stratigraphy and the possibility of correlation of individual tephra layers between three holes make Site U1443 a unique observatory of volcanic activity in this region over the last $5 \mathrm{My}$ (Figures F16, F17). The volcanic tephra layers are excellent tools for lithostratigraphic correlation of the marine sediment successions within the four different holes on the northern NER. Detailed studies of the tephra layers will contribute to the understanding of the magmatic evolution in the source region and allow determination and precise dating of eruptive cycles. In particular, the eruption history of the Toba Caldera in

Figure F15. Site U1443 splice RGB, magnetic susceptibility (loop and spot), $L^{*}, a^{*}, b^{*}$, and NGR data tuned to LR04 benthic isotope stack for the last 3.4 My.

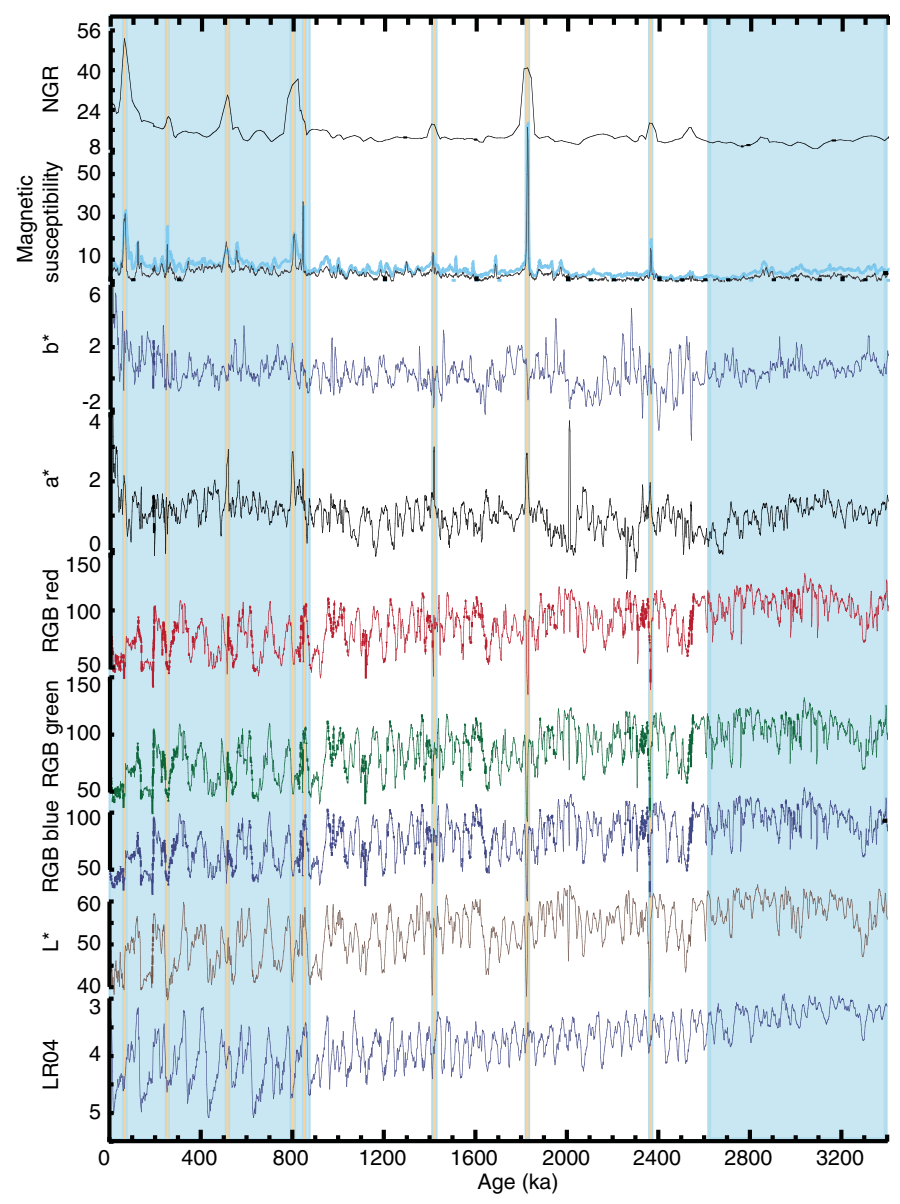


Figure F16. Toba Tephra layers D, d, and E in (A) Holes U1443A and (B) U1443B.
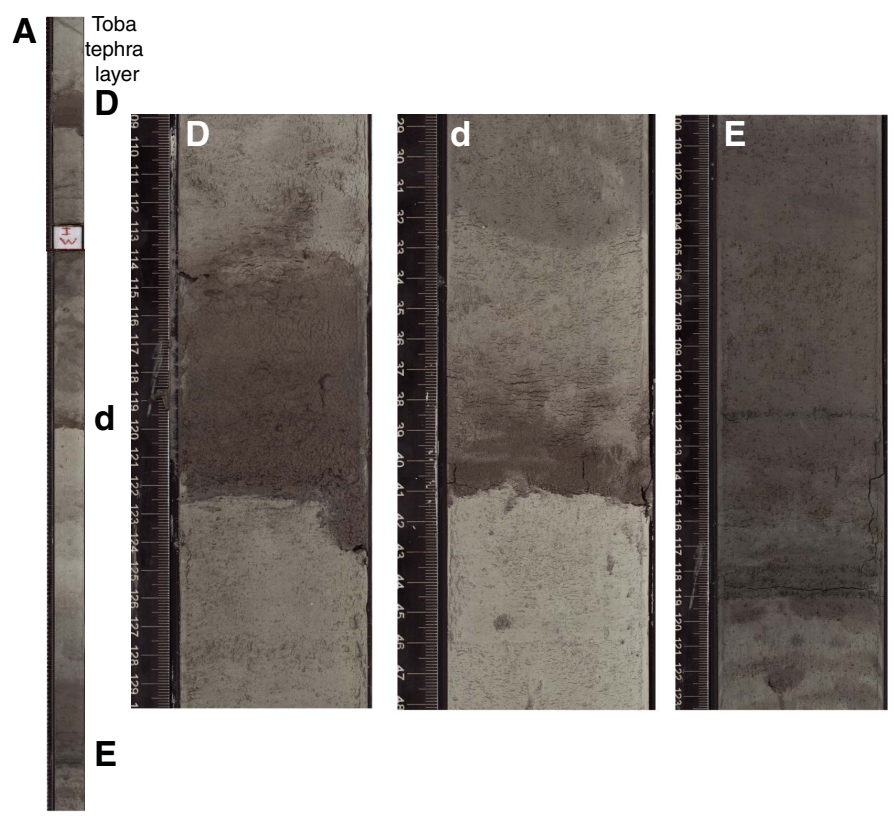

\section{B tophra}
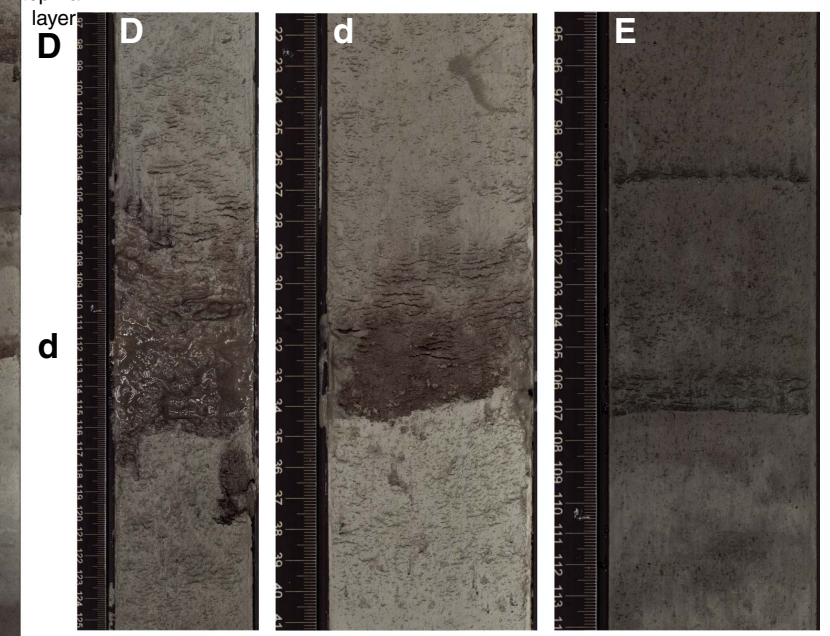

E

northern Sumatra is well documented on the northern NER (Ninkovich, 1979; Ninkovich et al., 1978; Dehn et al., 1991), and individual tephra layers at Site U1443 can be tentatively correlated to the main eruptions of the Toba Caldera complex at 75, 450, 840, and $\sim 200$ ka (Chesner and Rose, 1991; Dehn et al., 1991; Farrell and Janecek, 1991). The possibility of ${ }^{40} \mathrm{Ar} /{ }^{39} \mathrm{Ar}$ dating of these ash layers and correlation to a robust paleomagnetic reversal scheme at Site U1443 in combination with high-resolution stable isotope records will further contribute to intercalibrating Pliocene-Pleistocene geomagnetic reversal and $\delta^{18} \mathrm{O}$ chronostratigraphy (Hall and Farrell, 1993, 1995).

\section{Transitional Cretaceous/Paleogene boundary}

The sedimentary record of the Cretaceous/Paleogene (K/Pg) boundary transition was difficult to assess at Site 758 because this
Figure F17. Correlation of mudline cores in Holes U1443A, U1443B, U1443C, and U1443D.

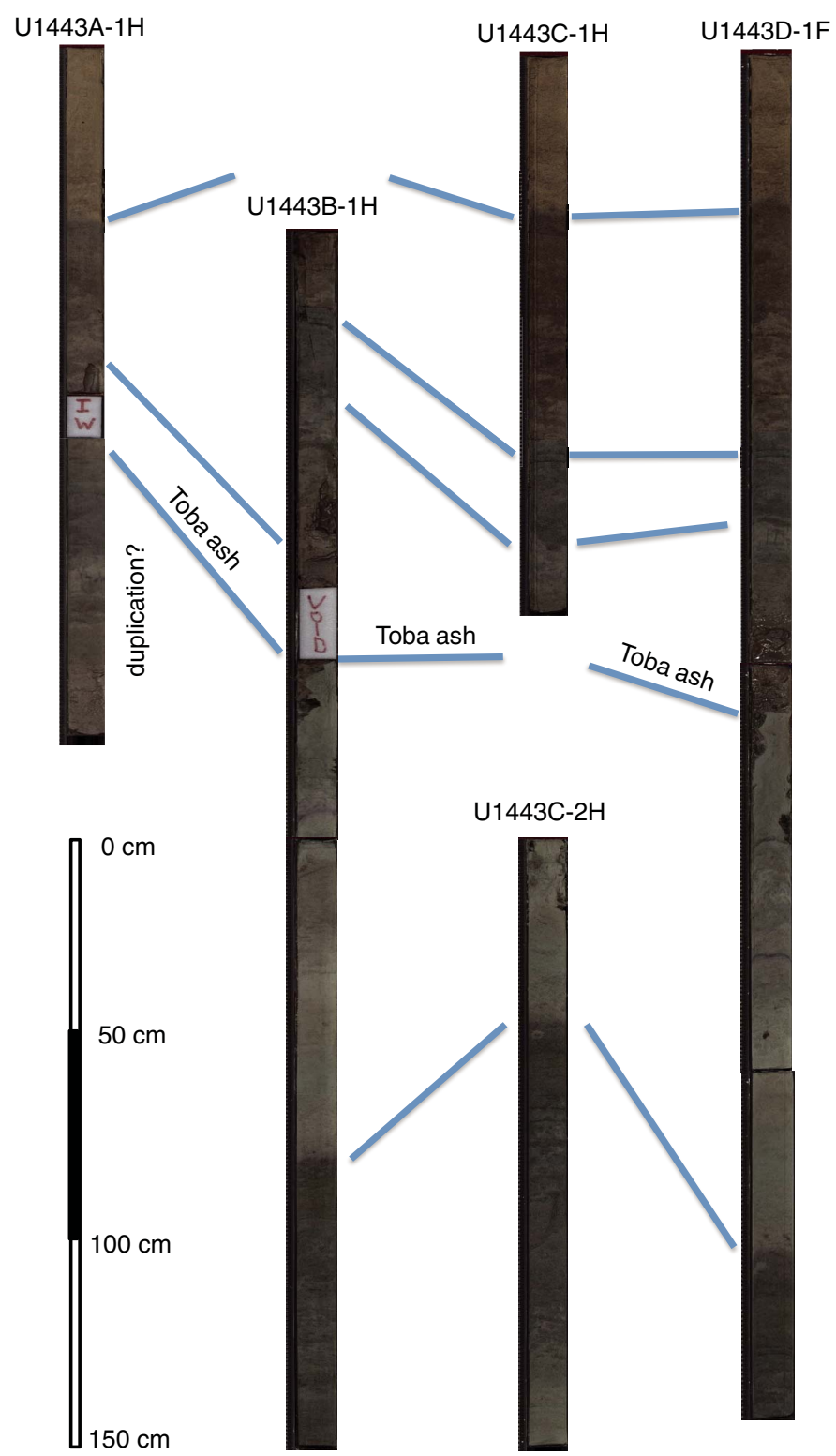

interval was only recovered in Hole 758A. The transition occurs at the base of the core catcher of Core 121-758A-31X (295.6 meters below seafloor [mbsf]) and is potentially incomplete because of the nearby coring gap between Cores 121-758A-31X and 32X. The Site U1443 K/Pg boundary (66.04 Ma) was identified between Samples 353-U1443A-39X-4W, $40 \mathrm{~cm}$, and 39X-5W, $60 \mathrm{~cm}$ (Figure F18). Sediments in this interval are heavily bioturbated (containing burrows, blebs, patches, color banding, and mottles), and most samples studied within this interval contain a mixture of Cretaceous and $\mathrm{Pa}-$ leocene nannoplankton species. In particular, Zoophycos spreite burrows are common in the $\mathrm{K} / \mathrm{Pg}$ boundary succession and are a prominent feature in upper Maastrichtian sediments of Holes U1443A and U1443B. The interval below Section 353-U1443A39X-5W contains moderately to poorly preserved Cretaceous nannofossil assemblages. No latest Maastrichtian marker events were found, possibly a result of a minor hiatus. 
Figure F18. Site U1443 Cretaceous/Paleocene transitional boundary.
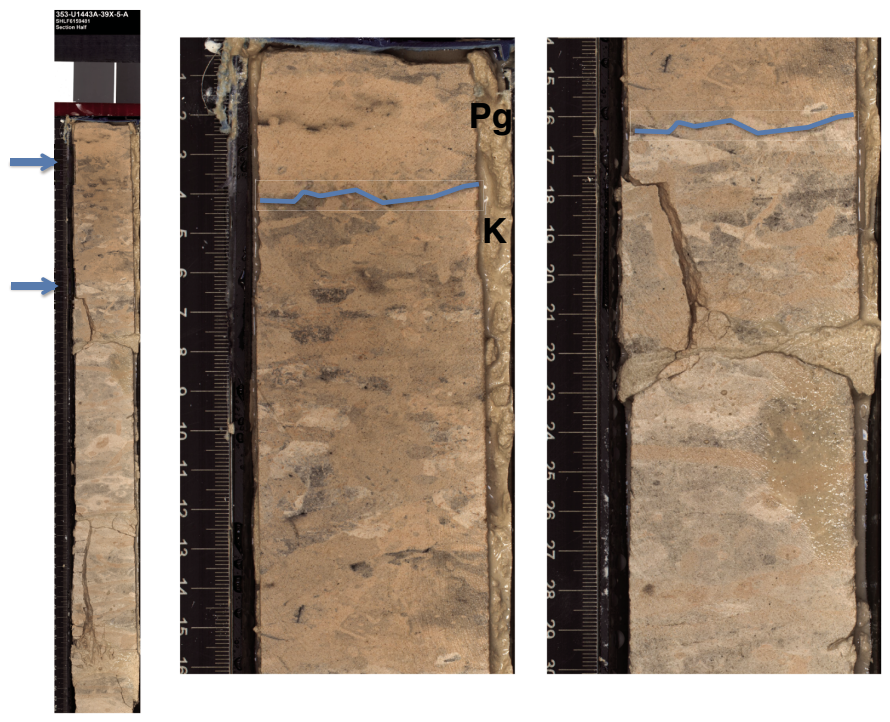

First complete spliced record of Neogene deepwater sediments in the Indian Ocean

The continuous pelagic sediment record of Site U1443 with well-preserved benthic and planktonic foraminifers will allow for the extension of existing Pliocene-Pleistocene isotope records from Site 758 to the base of the Neogene and tracking of deepwater and surface water isotopic signals in the eastern equatorial Indian Ocean over the last $25 \mathrm{My}$. Sedimentation rates $>0.41 \mathrm{~cm} / \mathrm{ky}$ will still allow analyses of stable isotopes and geochemical records in a resolution sufficient to resolve orbital-scale climate variability and to correlate these records to existing Atlantic and Pacific orbitally tuned isotope curves.

\section{Late Oligocene to middle Miocene paleomagnetic record}

The high-quality paleomagnetic record of Site 758 was limited to the uppermost $100 \mathrm{~m}$, which was retrieved by APC coring. Below this level, biscuiting of the cored sediment by XCB coring prohibited high-quality magnetic measurements. At Site U1443, it was possible to deploy the APC and HLAPC core barrels in sediment deeper than $200 \mathrm{~m}$ CSF-A, which opened up a new window for obtaining paleomagnetic records for the lower part of the Miocene and upper Oligocene. In particular, the record between 130 and 200 $\mathrm{m}$ CSF-A is characterized by high-quality paleomagnetic data that allow establishment of a complete paleomagnetic reversal scale that covers the entire lower Miocene and upper Oligocene, including the Oligocene/Miocene stage boundary.

\section{Recovery of expanded Campanian-Maastrichtian sediment succession}

The Campanian to Maastrichtian part of the succession at Site U1443 is characterized by moderate to high recovery of indurated yellowish brown nannoplankton chalk, which grades downcore into greenish glauconite-rich chalk with intervals of abundant Inoceramus shell fragments (Figure F19). The lower part of this interval includes several centimeter-thick indurated chert nodules and nodular layers, which caused a significant decrease in drilling progress and recovery in the lowermost two cores of Hole U1443A (Cores 353-U1443A-47X and 48X). The recovery of Upper Cretaceous sediments above these Campanian siliceous layers was good in both Holes U1443A and U1443B, resulting in a complete stratigraphic record of this interval, which was characterized by only
Figure F19. A. Transition from greenish glauconitic chalk to brownish-reddish nannofossil marls, Hole U1443A (42X-1). B. Glauconitic marl with inoceramid shell material (46X-1).
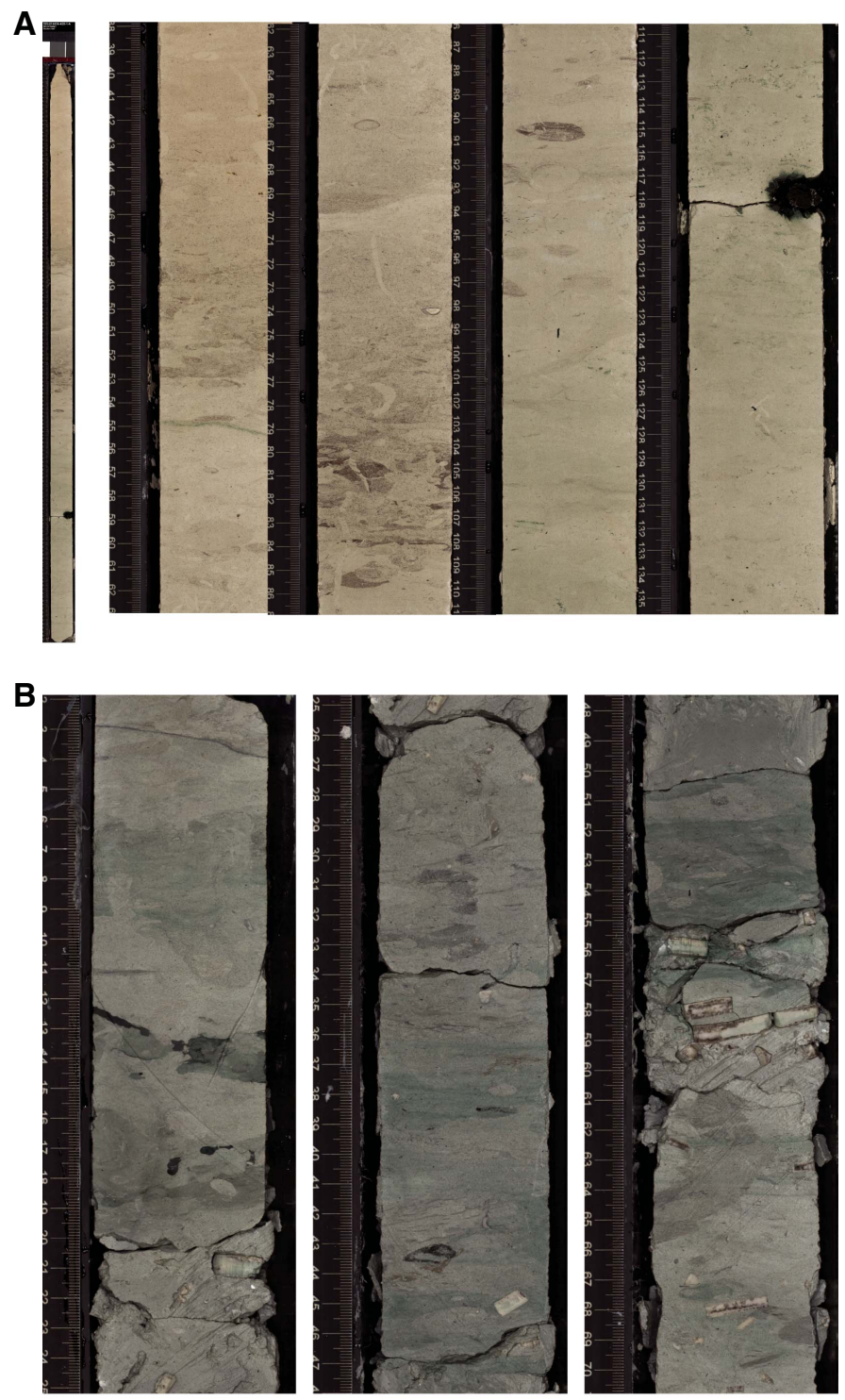

fragments recovered at Site 758. The low degree of diagenesis and the complete recovery may allow construction of a spliced bulk carbonate carbon isotope record that covers the entire Maastrichtian to the middle/late Campanian including the Campanian/Maastrichtian boundary.

\section{A note on the Hole U1443A CSF-A depth scale}

Stratigraphic and visual correlation indicates that $\sim 5.4 \mathrm{~m}$ of sediment was lost from the bottom of Core 353-U1443A-1H (Figure F20). This is not surprising in light of the fact that four APC core barrels were bent or broken during attempts to establish the various holes at Site U1443. In this case the addition of $\sim 5.4 \mathrm{~m}$ to the CSF-A depth of all cores below Core $1 \mathrm{H}$ is necessary to make the CSF-A depths more consistent with those in Holes U1443B-U1443D.

\section{Site U1444}

\section{Background and objectives}

The main scientific objective of Expedition 353 is to reconstruct changes in precipitation and runoff on suborbital to orbital time- 
Figure F20. Holes U1443A/U1443B correlation of Cores 353-U1443A-1H through $2 \mathrm{H}$ and $353-\mathrm{U} 1443 \mathrm{~B}-1 \mathrm{H}$ and $2 \mathrm{H}$, indicating a $5.4 \mathrm{~m}$ gap at the base of Core 353-U1443A-1H.

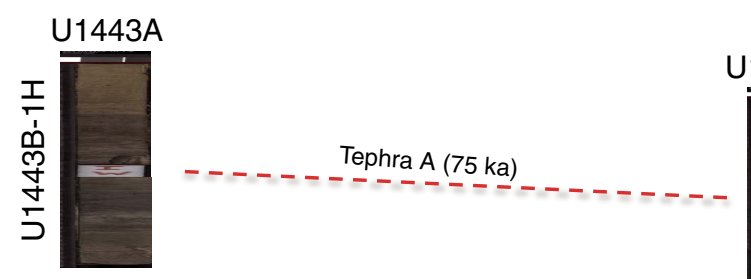

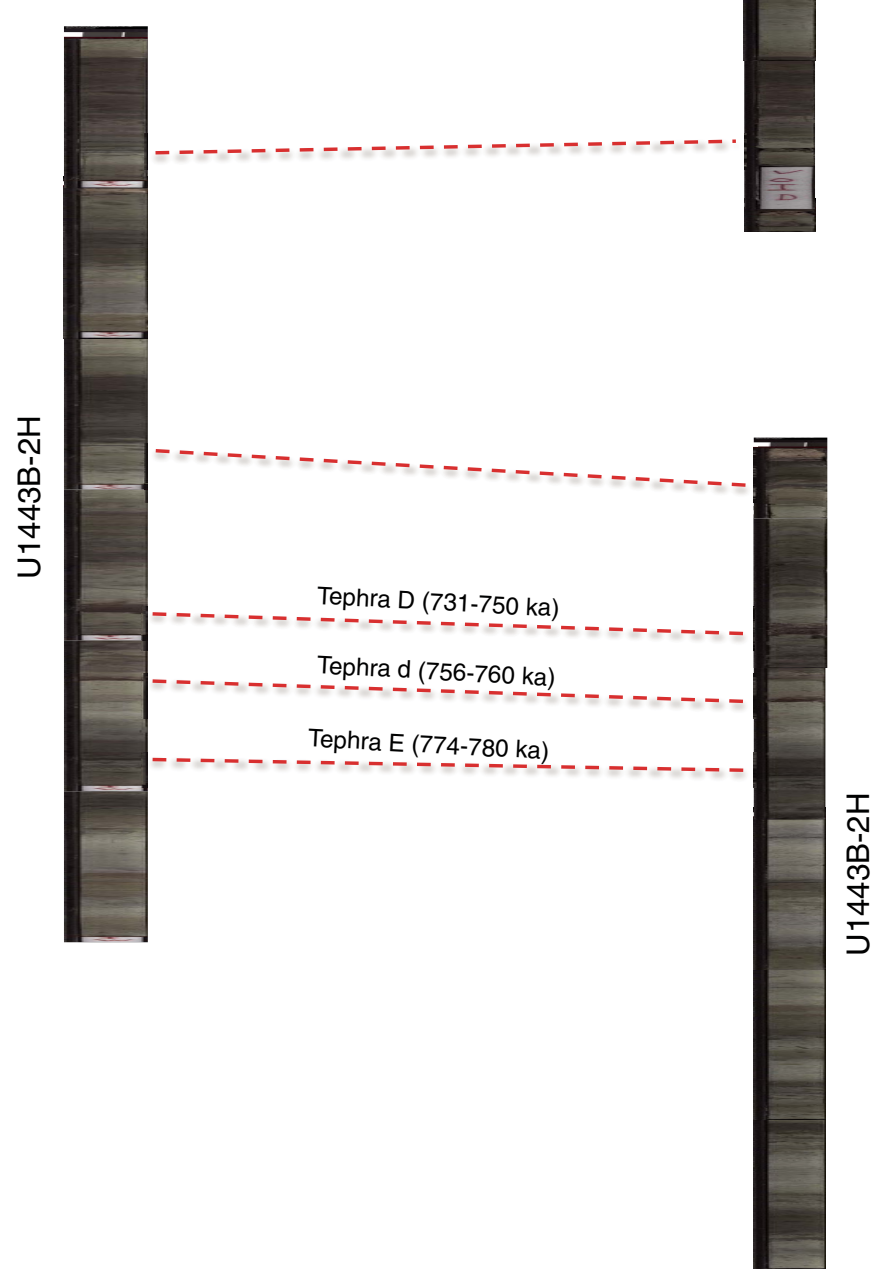

scales. To achieve this objective, site locations were selected according to the likelihood of continuous sedimentation and proximity to the main sources of freshwater feeding the Northern Bay of Bengal,

including the Mahanadi River and the Ganges-Brahmaputra river complex, and the Andaman Sea, including the Irrawaddy and Salween river systems.

One month prior to the start of the expedition, an alternate drilling plan was requested, one that included only sites in international waters. To accommodate this, we utilized existing site survey data acquired by colleagues at the University of Bremen in 1997 and 2006 to locate drilling targets in the central Bengal Fan, following a latitudinal transect approach. This alternate plan included sets of sites at three different latitudes in international waters at $11^{\circ} \mathrm{N}$, $14^{\circ} \mathrm{N}$, and $17^{\circ}$ to $18^{\circ} \mathrm{N}$.

Sediments at these alternative sites do not meet the paleoclimatic time-series oriented scientific objectives of Expedition 353 because the sedimentary archive of the Bengal Fan includes abundant coarse-grained turbidite sequences that do not have the stratigraphic integrity required for high-resolution reconstruction of climate change. However, the alternate sites on the Bengal Fan are complementary to the objectives of Expedition 354 (France-Lanord et al., 2014). One of the crucial issues for Expedition 354 is the continuity of the terrigenous flux from the Himalayan source to the $\sim 8^{\circ} \mathrm{N}$ drilling targets. Channel migration may, at times, decouple the middle fan from the supply. The addition of sites north of the $8^{\circ} \mathrm{N}$ Expedition 354 transect sites may help to evaluate these processes and provide additional material for the understanding of terrigenous flux into the Bengal Fan, one of the main objectives of the Expedition 354 drilling proposal.

Site U1444 $\left(14^{\circ} \mathrm{N}, 84^{\circ} 49.74^{\prime} \mathrm{E} ; 3132 \mathrm{mbsl}\right)$ is located at common midpoint (CMP) 1302 on seismic Line GeoB97-041 (Schwenk and Spieß, 2009) (Figure F21A; Table T1). The site is located in the western part of the lower Bengal Fan, close to the westernmost abandoned channel that fed the western part of the lower fan (Emmel and Curray, 1984). Seismics (Figure F21B-F21C) suggest that these sediments are composed of a series of buried channel-levee sequences incised into hemipelagic sediments atop the underlying $85^{\circ}$ E Ridge. Schwenk and Spieß (2009) identified two prominent seismic reflectors (Unconformities Uc and Ud) bounding a more transparent hemipelagic unit between 4.32 and 4.20 s two-way traveltime (TWT), corresponding to 105 to 185 mbsf. These unconformities can be traced for several hundred kilometers to the east along Line GeoB97-041 (Schwenk and Spieß, 2009). Similar regional-scale unconformities in the lower fan have been correlated to Site 218 and dated as earliest Pliocene $(\sim 4.8 \mathrm{Ma})$ and middle Pleistocene $(\sim 0.65 \mathrm{Ma})$ in age (von der Borch, Sclater, et al., 1974; Schwenk and Spieß, 2009). Unconformities Uc and Ud were inferred to be Pleistocene and Pliocene in age as well, but prior to drilling Site U1444, they had not been dated. Thus, a primary objective of this site was to determine the lithologic changes associated with Unconformities Uc and Ud and to date these reflectors in an effort to assess the degree to which turbidite and intercalated hemipelagic sequences are continuous from the upper to lower fan regions.

\section{Coring summary}

At Site U1444, Holes U1444A and U1444B were drilled to total depths of 330.6 and $128.6 \mathrm{~m}$ DSF, respectively (Table T1). In Holes U1444A and U1444B, the full-length (9.7 m long) APC system and the XCB system were primarily used. The HLAPC (4.7 m long) was used only for Core 353-U1444A-24F. For Holes U1444A and U1444B, the APC system was used to refusal followed by the XCB. A total of 46 cores were recovered at Site U1444. The APC cored interval was $160.0 \mathrm{~m}$ with a recovery of $156.21 \mathrm{~m}$ (98\% recovery). The HLAPC cored interval was $4.8 \mathrm{~m}$ with a recovery of $3.94 \mathrm{~m}$ of core $(82 \%)$. The XCB cored interval was $246.9 \mathrm{~m}$ with a recovery of 
Figure F21. (A) Location of Site U1444 (after Emmel and Curray, 1984), (B) seismic line, and (C) line-drawing interpretation (after Schwenk and Spieß, 2009). In the line drawing, gray indicates buried channel-levee systems and bold black lines indicate seismic unconformities (Uc and Ud). (Continued on next page.)

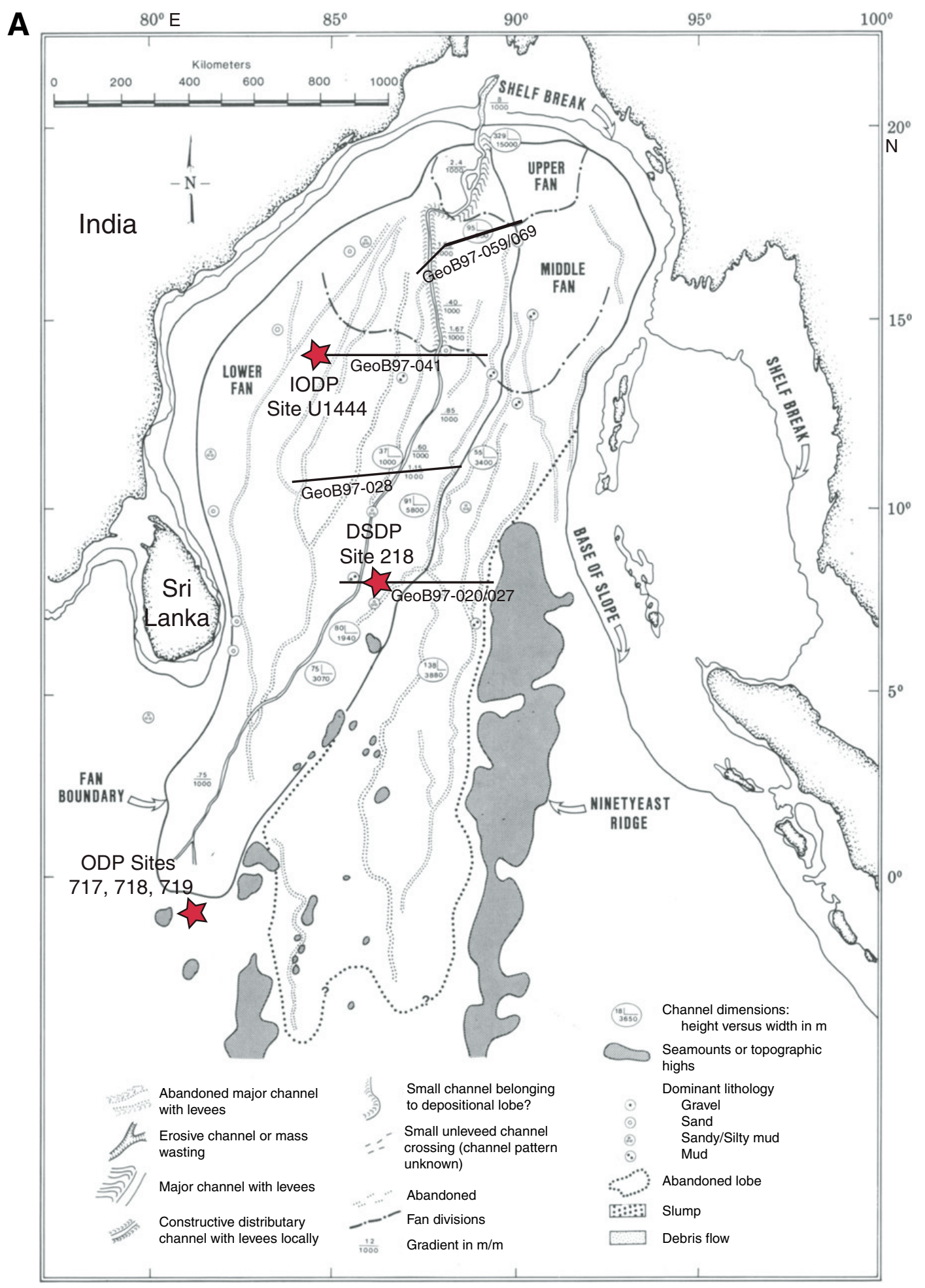

$140.06 \mathrm{~m}$ of core $(57 \%)$. Hole U1444B contained a drilled interval from 47.5 to $95.0 \mathrm{~m}$ DSF. The overall recovery for Site U1444 was $73 \%$.

\section{Lithostratigraphy}

Sediments recovered from Holes U1444A and U1444B can be divided into four lithostratigraphic units based on visual descrip- tion, smear slide analysis, and physical property measurements. The recovered lithologies are siliciclastic and are composed of turbidites with intercalated hemipelagic intervals.

- Unit I (0-95.01 m CSF-A) is composed of silty sand and silty clay with numerous turbidites. 
Figure F21 (continued).
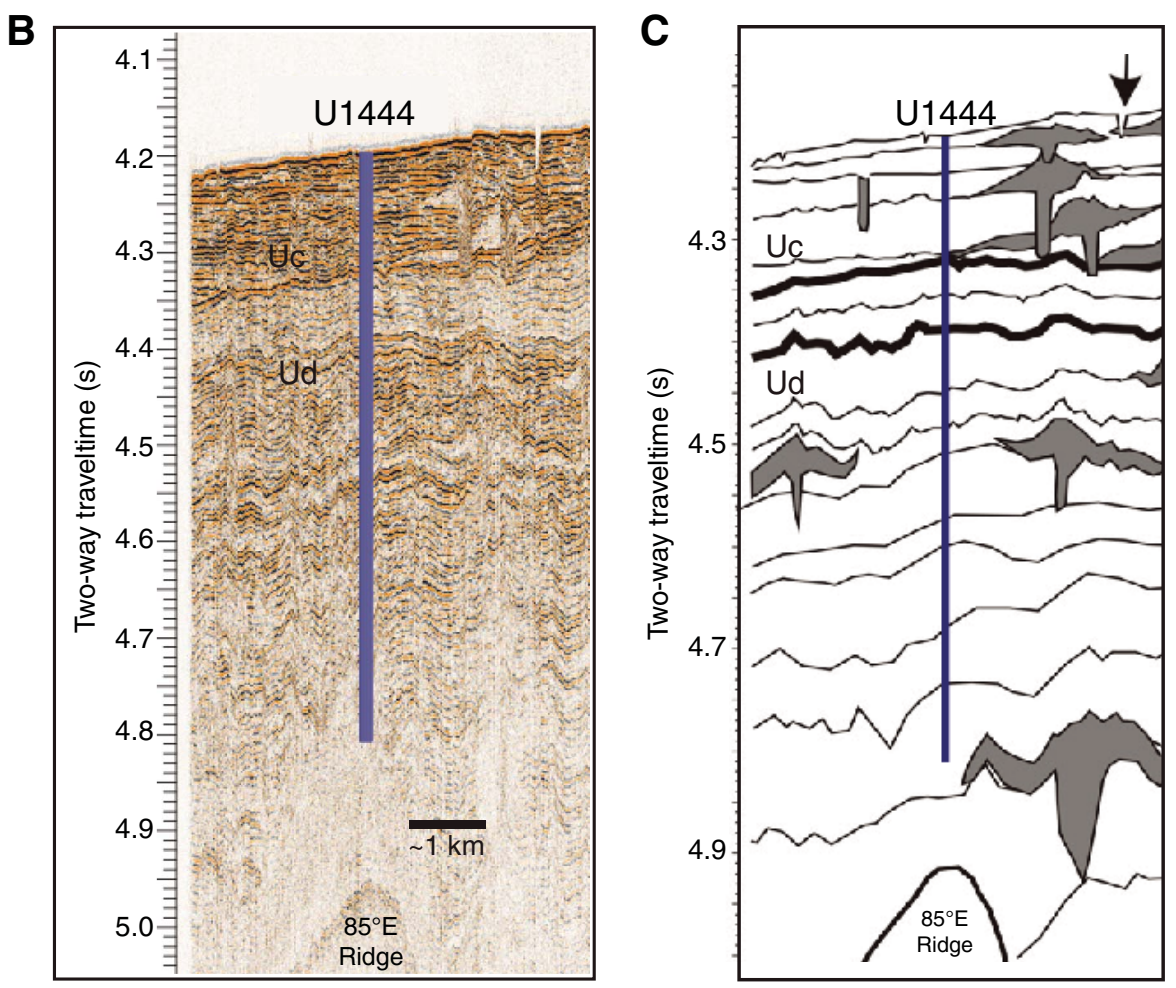

- Unit II (95.01-168.91 m CSF-A) is primarily nannofossil-rich clay with silt and foraminifers. Turbidites in Unit II are less abundant, thinner, and finer than in Unit I.

- Unit III (168.91-255.60 m CSF-A) is characterized by very poor recovery and is dominated by silty fine to medium sand.

- Unit IV (255.60-323.39 m CSF-A) is composed primarily of nannofossil-rich clay and clayey silt interbedded with sand and silt turbidites.

Turbidites at this site show typical erosional bases and normal (fining-upward) grading but rarely show structures typical of classic Bouma or Stow sequences (e.g., parallel, wavy, or lenticular laminae). Structureless turbidites suggest very rapid sedimentation and/or disturbance of the water-saturated sands during drilling and recovery. Turbidites were classified visually as either silt or sand as the maximum grain size. At Site U1444, turbidites can be classified compositionally from visual and smear slide descriptions as mica rich, well sorted quartz dominant, organic debris rich, or glauconite rich. The overall lithologic differences between units and variation in turbidite grain size and thickness are consistent with fluctuations in the proximity of active turbidity current channels on the Bengal Fan.

\section{Biostratigraphy}

The biostratigraphic age model for Site U1444 was established by combining calcareous nannofossil and planktonic foraminifer datums from Hole U1444A. Age-depth relationships for the two fossil groups show good agreement. All samples were nearly or completely barren of diatoms. Calcareous microfossils (nannofossils, planktonic foraminifers, and benthic foraminifers) at Site U1444 were rare or absent in turbidite-rich sequences and common to abundant in hemipelagic sediment sequences. Where calcareous microfossils were present, preservation was good to moderate and rarely poor. Foraminifers ranged in preservation from poor to good in the samples in which they occur.

Calcareous nannofossil assemblages were of Pleistocene to late Miocene age and tropical/subtropical in character. Most Pleistocene, Pliocene, and late Miocene calcareous nannofossil bioevents used to define the biostratigraphic zones were present. This enabled us to assign all samples from hemipelagic sediment sequences and many samples from turbidite-rich sequences to a single biozone. Emiliania huxleyi is present in Sample 353-U1444A-9H-CC near the bottom of lithostratigraphic Unit I, suggesting that this entire unit $(95 \mathrm{~m})$ was deposited during the Late Pleistocene and Holocene. The top of lithostratigraphic Unit II (95-177 m CSF-A) was placed within nannofossil Zone NN20. Sample 353-U1444A-20XCC (168.89 m CSF-A), near the base of Unit II, falls within nannofossil Zone NN16 (late Pliocene). The lithostratigraphic Unit IV sequence spans Zone NN13 (middle Pliocene) to Zone NN11 (late Miocene). Sample 353-U1444A-37X-CC, $18 \mathrm{~cm}$, collected $12 \mathrm{~cm}$ above the bottom of Hole U1444A, contained common Discoaster loeblichii, which suggests that the oldest sediments in Hole U1444A are younger than $7.53 \mathrm{Ma}$ (late Miocene).

Planktonic foraminifer assemblages in Hole U1444A are tropical to subtropical throughout the Neogene and include species indicative of upwelling. The last occurrence (LO) of Globigerinoides ruber (pink) in Sample 353-U1444A-4H-CC and the first occurrence (FO) of Globorotalia flexuosa in Sample 14X-CC indicate that sediments between 35.83 and $119.42 \mathrm{~m}$ CSF-A are of Pleistocene age. Pliocene datums were found in Samples 16X-CC through 19X-CC (137.41$166.53 \mathrm{~m}$ CSF-A) and in Cores 32X and 33X (283.02-290.50 m CSF-A). Eleven core catcher samples from 168.89 to $270.34 \mathrm{~m}$ CSF-A were either barren or contained no index species. Miocene 
sediments are identified in Samples 35X-CC and 36X-CC. The occurrence of Candeina nitida in Sample 36X-CC indicates that it can be no older than $8.43 \mathrm{Ma}$.

Site U1444 is characterized by large variations in sedimentation rate that occur because of high-frequency large-scale episodes of sediment redeposition. Mean sedimentation rates reach $>20 \mathrm{~cm} / \mathrm{ky}$ in lithostratigraphic Unit I (0-95 m CSF-A) and $>30 \mathrm{~cm} / \mathrm{ky}$ in Unit III (168.91-255.60 m CSF-A). Lithostratigraphic Units II and IV are mostly hemipelagic with sedimentation rates an order of magnitude lower than in Units I and III, around $1.39 \mathrm{~cm} / \mathrm{ky}$ for Unit II and 1.60 $\mathrm{cm} / \mathrm{ky}$ for Unit IV.

\section{Geochemistry}

Site U1444 varies geochemically, reflecting the depositional history of this section of the Bengal Fan. Significant changes in sediment and pore water chemistry reflect the major changes in lithology. Lithostratigraphic Unit I features a complete drawdown of sulfate and increases in methane, alkalinity, and nutrients. Deeper units are less reducing with opposing trends in many elements, including pronounced secondary peaks in sulfate, silicate, $\mathrm{B}, \mathrm{Li}, \mathrm{Mn}$, and $K$. Organic $C$ is low but variable, ranging between 0 and $2 \mathrm{wt} \%$, whereas carbonate content tracks lithostratigraphic units: Units I and III are low, whereas Units II and IV are variable but generally higher (10-30 wt\%).

\section{Paleomagnetism}

Paleomagnetic measurements were conducted on archive-half sections for both Holes U1444A and U1444B. Sections dominated by sand were not measured because of their unstable texture and the risk of contamination to the magnetometer. All sections from $\mathrm{XCB}$ cores were severely affected by drilling-related overprint and were difficult to interpret. A selection of discrete samples $(N=119)$ taken from working-half sections was also analyzed. Based on APC section measurements and discrete sample data, we propose tentative magnetozones throughout Hole U1444A. Magnetostratigraphic ages are given as $0.781 \mathrm{Ma}$ at $\sim 112-118 \mathrm{~m}$ CSF-A and 2.581 $\mathrm{Ma}$ at $\sim 148-151 \mathrm{~m} \mathrm{CSF-A}$. Other magnetozones were difficult to correlate with the geomagnetic polarity timescale because of poor recovery in some intervals and drilling-related overprint remanence. Most of the discrete data downhole to $\sim 100 \mathrm{~m}$ CSF-A are influenced by gyroremanent magnetization, likely due to the presence of greigite (a ferrimagnetic iron sulfide). A rock magnetic evaluation of greigite abundance revealed a depth distribution in broad agreement with interstitial water geochemistry.

\section{Physical properties}

Downhole variations in physical property measurements at Site U1444 reflect changes in lithology, condensed sections associated with depositional hiatuses, and diagenetic processes. The overall suite of physical property data is divided into four broad physical property units in Hole U1444A (PP Units A1-A4) and three broad physical property units in Hole U1444B (PP Units B1-B3). The turbiditic lithostratigraphy is the primary reason why units in Holes U1444A and U1444B do not correspond well to each other. However, some general observations remain valid for both holes. First, MS values are higher in coarse-grained sediments than in clay-rich sections. Second, core-length MS trends show high values at the bottom of cores and low values at the top, possibly indicating mechanical sorting at core-length scales. These trends are mainly present in the APC cores that are almost entirely composed of coarse and watery sands, suggesting that settling of the coarse-grained fac- tion, which is generally associated with magnetic material, could have occurred from severe disturbance during coring and recovery. Third, throughout the hole the physical property data are highly variable, which makes it challenging to reliably interpret them for subtle changes in sediment type and character.

\section{Stratigraphic correlation}

No composite depth scale or splice was constructed for Site U1444. Coring disturbance and mechanical sorting of turbidite sands led to a restructuring of the physical properties on a core-bycore basis in the upper part of the site (see Physical properties), and a lack of signal in the XCB cores in the lower part of the site prevented establishment of reliable tie points between Holes U1443A and U1444B.

\section{Highlights: dating seismic Unconformities Uc and Ud in Hole U1444A}

The middle Bengal Fan is characterized by channel-levee systems that are erosionally incised into underlying hemipelagic sediments (Schwenk and Spieß, 2009). Seismic profiles indicate two major regional unconformities, which were dated at Site 218 as earliest Pliocene ( 4.8 Ma) and Middle Pleistocene (0.65 Ma) (von der Borch, Sclater, et al., 1974; Schwenk and Spieß, 2009). The extent of the regional unconformities, the onset of levee systems, and faults terminating within Pleistocene sediments suggest that tectonic events, in addition to changes in sediment supply and transport, exerted major controls on the sedimentation patterns of the Bengal Fan (Schwenk and Spieß, 2009).

Regional Unconformity Uc (Schwenk and Spieß, 2009) is clearly recognizable in the sedimentary succession of Site U1444. It is defined by a lithologic change from hemipelagic clays and silty clays (with foraminifer and nannofossil ages of $\sim 200 \mathrm{ka}$ ) to a turbiditedominated sequence composed of silty sands and silty clays that are largely barren of microfossils. This $95 \mathrm{~m}$ long sequence represents the last $200 \mathrm{ky}$ of sedimentary deposition at Site U1444. The deeper regional unconformity (Ud in Schwenk and Spieß, 2009) is characterized by a change from very poorly recovered turbiditic silty sands and clayey silts to hemipelagic clays and silty clays in the middle Pliocene (between 3.6 and 3.8 Ma). Within the error of the dating, which includes sedimentation rate-based extrapolations over tens of meters at Site 218, the Late Pleistocene regional Unconformity Uc could be the same age as the unconformity at Site 218. The deeper Pliocene Unconformity Ud at Site U1444 appears to be on the order of $1 \mathrm{My}$ younger relative to the unconformity at Site 218.

The onset of channel-levee systems in the latest Miocene is indicated by downhole data from ODP Leg 116 and seismic data along an east-west transect at $8^{\circ} \mathrm{N}$ (Schwenk and Spieß, 2009). These changes were possibly related to changes in the erosion and weathering regime in the drainage area of the Ganges River (Schwenk and Spieß, 2009). At Site U1444, the oldest sediments of Hole U1444A (3.8 to $\sim 6 \mathrm{Ma}$ ) consist of fine-grained mudstones with intercalated thin-bedded levee sediments followed by a strong increase in coarse-grained silty-sandy levee and turbidite sediments representing a fan lobe deposit in the middle Pliocene around 3.8 Ma.

\section{Site U1445}

\section{Background and objectives}

Site U1445 (2503 mbsl) is located near the southern end of the Mahanadi basin, on the eastern margin of India (Figure F2). This location, $\sim 94 \mathrm{~km}$ offshore, offers the opportunity to drill sediments underlying the low-salinity waters of the Indian margin, a result of 
summer monsoon rainfall and runoff from the peninsular rivers of India, including the Ganges-Brahmaputra river complex and the Mahanadi River. The location of this site, seaward of the base of the slope, offers the potential to reach Miocene sediments but is not protected from turbidite deposition. Objectives at this site were to recover late Miocene to Holocene sediment sections in order to reconstruct changes in the Indian summer monsoon at orbital to suborbital timescales.

\section{Coring summary}

At Site U1445, Holes U1445A, U1445B, and U1445C were drilled to total depths of 672.6, 33.0, and $305.2 \mathrm{~m} \mathrm{DSF}$, respectively (Table T1). In Holes U1445A and U1445C, the APC and XCB systems were primarily used; only the APC system was used in Hole U1445B. For Holes U1445A and U1445C, the APC system was used to refusal. Following refusal of the $\mathrm{APC}$, the $\mathrm{XCB}$ was deployed to total depth. Overall, 117 cores were recorded for the site. A total of $487.34 \mathrm{~m}$ of core over a $476.3 \mathrm{~m}$ cored interval was recovered using the APC (102\% recovery). The cored interval with the XCB was $534.5 \mathrm{~m}$ with a core recovery of $518.02 \mathrm{~m}$ (97\%). The overall recovery percentage for Site U1445 was $99 \%$. The total time spent on Site U1445 was 9.3 days.

\section{Lithostratigraphy}

Sediments recovered from Holes U1445A-U1445C are principally composed of hemipelagic clays with a significant biogenic component and occasional thin turbidites of Late Pleistocene (Holocene?) to late Miocene age. Because of the consistent fine-grained nature of the sediments, only one stratigraphic unit is recognized and divided into two subunits (Ia and Ib), primarily based on nannofossil and biosilica content:

- Subunit Ia (0-165.28 m CSF-A) is a sequence of Late Pleistocene (Holocene?) to Middle Pleistocene olive-gray to dark greenish gray clay with biosilica and clay with nannofossils, with occasional beds of biosilica-rich clay.

- Subunit Ib (165.28-667.56 m CSF-A) comprises the interval between the first downcore occurrence of biosilica-rich clays to the bottom of Hole U1445A, and spans the Middle Pleistocene to late Miocene.

Foraminifers are a persistent but variable component of the Subunit Ia clays, whereas calcareous nannofossils become less abundant downhole. Subunit Ib is dominated by very dark greenish gray biosilica-rich clay with glauconite, with significant intervals of increased diatom content between $\sim 160$ and 330 m CSF-A. Foraminifers and nannofossils are both much less common in Subunit Ib than in Subunit Ia but are present in small numbers throughout, particularly between $\sim 570$ and 670 m CSF-A where an increase in calcareous nannofossils is observed. Thin $(\sim 2-20 \mathrm{~cm})$ turbidites are present in sediments from both Subunits Ia and Ib, varying in composition from silt-sized quartz-rich silt/sands to foraminifer-rich sands with occasional bioclastic-rich sands. Soupy and mousselike intervals, characteristic of gas hydrate dissociation, were identified in sediments recovered using the APC system in Holes U1445AU1445C from both Subunits Ia and Ib. Overall, cores from Hole U1445C were considerably less disturbed (drilling disturbance and gas expansion) than those recovered from Hole U1445A at equivalent depths, possibly due to reduced heave during Hole U1445C operations.

\section{Biostratigraphy}

Calcareous and siliceous microfossils are present in Hole U1445A with variable downcore abundance trends. Calcareous nannofossil preservation is good to moderate, and abundances vary between rare and abundant. Pleistocene to late Miocene nannofossil assemblages are typical of tropical/subtropical paleoenvironments. Foraminifers are dominant to abundant in the uppermost $188 \mathrm{~m}$ in Hole U1445A. Abundance decreases rapidly deeper than $188 \mathrm{~m}$ CSF-A and falls to few or rare deeper than $290 \mathrm{~m}$ CSF-A. Foraminifer preservation is good to moderate, with the exception of three samples that show poor preservation. Diatom preservation ranges from good to poor and tends to be better when diatom abundance is higher.

All Pleistocene nannofossil marker species were found, with the exception of Reticulofenestra asanoi. The Pliocene/Pleistocene boundary (2.59 Ma), located between Cores 353-U1445A-31X and $38 \mathrm{X}$, is bracketed by a number of Discoaster LOs that are dated between 2.39 and 2.8 Ma. The Miocene/Pliocene boundary (5.33 Ma) is well constrained between 603.22 and $606.19 \mathrm{~m} \mathrm{CSF-A} \mathrm{and} \mathrm{is}$ based on the LO of Triquetrorhabdulus rugosus (5.28 Ma) and the FO of Ceratolithus acutus (5.35 Ma) in this interval. The oldest calcareous nannofossil sample studied (Sample 353-U1445-A-77XCC; 667.46 m CSF-A) contained Discoaster quinqueramus and Discoaster berggrenii, suggesting an age between 5.59 and $7.53 \mathrm{Ma}$. Beyond the age model, nannofossil biostratigraphy was of great use in dating rip-up clasts found in several horizons in Holes U1445A and $\mathrm{U} 1445 \mathrm{C}$. The matrix surrounding the clasts was of the same age as the sediment above and below the horizons containing the clasts, whereas the rip-up clasts themselves were of different ages, ranging from Late Pleistocene to late Eocene.

The percentage of planktonic foraminifers is high (mean = $86.4 \%$ ) in the uppermost $158.97 \mathrm{~m}$ of Hole U1445A but lower (mean $=59.9 \%$ ) throughout the remaining Hole U1445A core catchers. The total number of foraminifers per $10 \mathrm{~cm}^{3}$ raw sediment is highly variable, ranging from 0 to $>24,000$, with a marked decrease in numbers deeper than $180 \mathrm{~m}$ CSF-A. The number of benthic foraminifers per $10 \mathrm{~cm}^{3}$ raw sediment follows the same pattern, averaging 1667 between 0 and $180 \mathrm{~m}$ CSF-A and 129 in deeper sediments. Reworking is apparent in many late Miocene through Pleistocene samples. Pleistocene planktonic foraminifer assemblages were recovered from 6.9 to $261.51 \mathrm{~m}$ CSF-A. Pleistocene planktonic assemblages are dominated by tropical to warm subtropical species and by some temperate species. Species commonly associated with upwelling zones are common to abundant throughout Samples 353U1445A-1H-CC through $20 \mathrm{H}-\mathrm{CC}$, indicating coastal upwelling or vertical mixing of water masses. Species of markedly different last appearance datums are found within a zone encompassing Samples $9 \mathrm{H}-\mathrm{CC}$ through $18 \mathrm{H}-\mathrm{CC}$, which implies reworking. Pliocene planktonic foraminifer assemblages were recovered from Samples 29XCC through 68X-CC. Miocene sediments span Samples 69X-CC through 77X-CC. The occurrence of Globigerinoides conglobatus in Sample 76X-CC suggests a maximum age for this sample of 6.20 Ma.

Diatoms are useful for age estimation throughout the entire sedimentary column of Hole U1445A. Several diatom events were recognized between the LO of Nitzschia reinholdii (0.90-1.0 Ma) and the LO of Nitzschia miocenica (5.7 Ma). Valve preservation is mostly good to moderate. Strong variations in abundance and shifts in the species composition of the diatom assemblage will help to re- 
construct paleoceanographic changes in the eastern Bay of Bengal between the late Miocene and the Late Pleistocene. The highly diverse diatom community mainly consists of species typical of warm to temperate low-latitude ocean waters. High-productivity species, including Thalassionema nitzschioides var. nitzschioides and resting spores of Chaetoceros, tend to dominate whenever total diatom abundance is higher than "few." A certain degree of freshwater/terrigenous input is revealed by the recurrent presence of numerous phytoliths and freshwater diatoms.

The age model for Site U1445 was established by combining calcareous nannofossil, planktonic foraminifer, and diatom datums with paleomagnetic reversal datums. Age-depth relationships for Hole U1445A of the three fossil groups show good agreement and match the magnetochron boundary datums well. The combined biostratigraphic/magnetostratigraphic age model suggests a mean sedimentation rate of $11.4 \mathrm{~cm} / \mathrm{ky}$, assuming a linear fit of all data.

\section{Geochemistry}

The geochemistry of Site U1445 strongly reflects the processes of sulfate reduction and methanogenesis associated with microbial degradation of organic matter. High methane concentrations are found in headspace and void space gas samples. A high methane/ethane ratio suggests that the methane is mostly of biogenic origin. The organic $\mathrm{C}$ content is as high as $4 \mathrm{wt} \%$, and carbonate is associated with intervals of more abundant calcite microfossils. The pore water chemistry of Site U1445 reflects reducing conditions with sulfate depleted at around $18 \mathrm{~m} \mathrm{CSF-A.} \mathrm{Other} \mathrm{examples} \mathrm{are}$ alkalinity peaking at around $30 \mathrm{mM}$ near $50 \mathrm{~m}$ CSF-A and dissolved $\mathrm{Ba}$ and silicate increasing downhole. The influence of seawater contamination and oxygenation during activities associated with XCB coring is noticeable in the profiles of some ions, most notably sulfate, phosphate, and Fe.

\section{Paleomagnetism}

Paleomagnetic measurements were conducted on archive-half sections for all three holes at Site U1445, with alternating field (AF) demagnetization up to $10 \mathrm{mT}$. Discrete samples $(N=219)$ taken from working-half sections were also analyzed, with AF demagnetization typically up to $30 \mathrm{mT}$. Characteristic remanent magnetizations (ChRMs) of discrete samples were calculated using the principal component analysis (PCA) technique.

Remanence intensities, in addition to bulk magnetic parameters, drop significantly in the uppermost 10-20 m because of diagenetic reduction. Nonetheless, a fairly straightforward magnetic polarity stratigraphy was constructed, except for the lower part of Hole U1445A (deeper than $\sim 4$ Ma or $\sim 470$ m CSF-A). Rock magnetic measurements on discrete samples show promising variations in the bulk magnetic properties for the last $6 \mathrm{My}$. The significance of these trends has yet to be evaluated; however, a periodicity, possibly on the order of 40-60 ky, may be revealing astronomical-scale cycles.

\section{Physical properties}

Downhole variations in physical property measurements at Site U1445 reflect changes in lithology, condensed sections associated with depositional hiatuses, and diagenetic processes. Based on significant transitions within the data, the overall suite of physical property data is divided into three broad PP units (1-3) in Hole U1445A. Due to a shorter drilling depth, only the first two of the three physical property units could be identified in Hole U1445C. Unit 2 is characterized by anomalous porosity preservation. Smear slide analysis suggests that the prevalence of diatom-rich clay has enhanced the porosities while maintaining a low MS, density, and NGR. It also appears that the change in color reflectance from Units 1 to 2 could be a result of transition to XCB coring from APC coring. Unit 3 is characterized by high NGR peaks, which may be related to drilling disturbance or coarse-grained fractions that are likely to occur in the few turbiditic layers that were identified.

\section{Stratigraphic correlation}

A composite scale (CCSF-A) and a splice (CCSF-D) were constructed for Site U1445 using MS, NGR, and red, green, and blue (RGB) data from Holes U1445A and U1445C. Splicing among these holes enabled us to construct a continuous stratigraphic sequence to $\sim 252 \mathrm{~m}$ CCSF-D. Because of shipboard data quality issues, correlation should be viewed with caution deeper than $\sim 50 \mathrm{~m}$ CCSF-A and especially deeper than $\sim 236$ m CCSF-A.

\section{Downhole logging}

Wireline logging in Hole U1445A was initiated following coring operations. The hole was swept with a heavy-weight water-based mud that included barite as a weighting additive to improve hole stability. The presence of barite attenuates gamma rays, lowers the NGR measurements, and affects (increasing) the photoelectric factor. Therefore, the effects of barite in the mud on the log data needs to be taken into consideration when interpreting the data. Two logging passes were made, but a bridge was encountered at $\sim 440 \mathrm{~m}$, which prevented the tools from descending any further. The upper $80 \mathrm{~m}$ of the hole was not logged as it was occupied by the drill string. The first logging run was made with the triple combo and the second pass was made with the Formation MicroScanner tool. The wireline logging suite is divided into three units based on hole conditions inferred from the caliper data. The caliper data for Units 1 (100-237 m CSF-A) and 3 (380-440 m CSF-A) show highly irregular hole conditions with large washout zones and reduce the confidence in the data quality for these units. The caliper data for Unit 2 (237-380 m CSF-A) show that the hole is close to bit size. NGR counts were found to agree in magnitude with shipboard Natural Gamma Radiation Logger logs, and the wireline density data are in excellent agreement with moisture and density measurements, suggesting that the data in this unit are reliable. However, the density logs from the Whole-Round Multisensor Logger and Special Task Multisensor Logger appear to consistently underestimate the true density of the formation. Neutron porosity data suggest higher apparent porosity than density porosity as a result of water bound in the structure of the clays that dominate the downhole lithology. There are no resistivity spikes suggestive of concentrated gas hydrate occurrence, and thus the gas hydrate at this site, if present, could be dispersed.

\section{Highlights}

Sediments at this site were remarkably conducive to XCB coring. The deepest hole at Site U1445 was cored to $673 \mathrm{mbsf}, 447 \mathrm{~m}$ of which was cored using the XCB, with an overall recovery of $99 \%$. Within intervals where core expansion was strong because of microbial gas, an $8 \mathrm{~m}$ advance of the $9.5 \mathrm{~m} \mathrm{XCB}$ was employed to provide expansion room within the liner, thereby significantly reducing the loss of sediment out of the top of the corer.

Discrete intervals in the late Miocene, middle Pliocene, and Middle Pleistocene are characterized by abundant diatoms, including species characteristic of high-productivity environments and those found in coastal and freshwaters. Similarly, species of plank- 
tonic foraminifers characteristic of higher productivity environments increase in abundance in the middle Pliocene and Pleistocene, possibly suggesting nutrient input related to changes in surface water stratification or runoff.

All cores were infrared scanned on the catwalk prior to sectioning. A number of centimeter-scale cold spots were detected, having up to $7^{\circ} \mathrm{C}$ difference relative to background core temperatures. Rhizon pore water sampling indicated chloride values well below that of seawater, confirming these anomalies as hydrates.

Splicing among overlapping holes (0 to $\sim 305 \mathrm{~m})$ at Site U1445 will yield the first continuous section recovered from the Indian margin that spans the Pleistocene. Over this interval, fine-scale turbidites averaged $\sim 1$ per core $(<5 \mathrm{~cm}$ thick). Excellent XCB recovery (99\%) over the remaining $\sim 360 \mathrm{~m}$ will allow for high-resolution monsoon reconstruction into the late Miocene.

\section{Site U1446}

\section{Background and objectives}

Site U1446 (1430 mbsl) is located within the Mahanadi basin on the eastern margin of India (Figure F2). This location, $\sim 70 \mathrm{~km}$ offshore, offers the opportunity to drill sediments underlying the lowsalinity waters of the Indian margin, a result of summer monsoon rainfall and runoff from the peninsular rivers of India, including the Ganges-Brahmaputra river complex and the Mahanadi River. Located atop a small rise near the base of the slope, this site should be protected from turbidite deposition. Objectives at this site were to recover Late Pleistocene to Holocene sediment sections in order to reconstruct changes in the Indian summer monsoon at orbital to suborbital timescales.

\section{Coring summary}

At Site U1446, Holes U1446A, U1446B, and U1446C were drilled to total depths of 180.0, 27.1, and $182.0 \mathrm{~m}$ DSF, respectively (Table T1). In Holes U1446A and U1446C, the APC and HLAPC systems were deployed. In Hole U1446B, only the APC system was used. Overall, 47 cores were recorded for the site. A total of 344.95 $\mathrm{m}$ of core over a $342.3 \mathrm{~m}$ cored interval was recovered using the APC system (101\% recovery). The HLAPC cored interval was 46.8 $\mathrm{m}$ with a recovery of $49.43 \mathrm{~m}$ of core $(106 \%)$. The overall recovery percentage for Site U1446 was 101\%. The total time spent on Site U1446 was 2.3 days.

\section{Lithostratigraphy}

Sediments recovered from Holes U1446A-U1446C are Holocene to Middle Pleistocene in age and are a hemipelagic mixture of a dominant lithogenic fraction diluting a minor biogenic fraction. They are primarily composed of dark gray to gray clay with nannofossils, nannofossil-rich clay, clay with foraminifers, clay, clay with biosilica, and biosilica-rich clay. Because of the consistent clayey nature of the sediments, only one lithostratigraphic unit (Unit I) is recognized at this site (0-180.11 m CSF-A) with no subunit divisions. Visual core description and smear slide observations were used with supporting information from physical properties (primarily NGR) and geochemical parameters (weight percent $\mathrm{CaCO}_{3}$ ) to evaluate the varying abundances of the siliciclastic fraction (clays, silts, and occasionally sands) versus the biogenic fraction (calcareous and siliceous). Turbidites are rare at Site U1446, with only occasional thin quartz-rich or shallow-water carbonate-rich intervals indicative of transported sediments. Overall, drilling disturbance is generally slight to moderate, as all cores were retrieved using the APC system, characterized by voids and gas expansion cracks.

\section{Biostratigraphy}

Calcareous microfossils are continuously present in the sediments of Hole U1446A, whereas siliceous microfossils are sporadically present. Calcareous nannofossils show abundances ranging from few to abundant in the smear slides studied, and their preservation is generally very good to good and occasionally moderate. Foraminifers are dominant to abundant in Hole U1446A in 19 of 21 core catcher samples and common or few in the remaining two samples. Preservation is good to moderate in all foraminifer samples. Diatoms are present in the lower and upper part of the Hole U1446A record. Valve preservation ranges from good to poor and tends to be better when abundance is higher.

All Late Pleistocene calcareous nannofossil events were identified. Late to Middle Pleistocene assemblages are typical of tropi$\mathrm{cal} /$ subtropical paleoenvironments. All core catcher samples from Hole U1446A contain Pleistocene planktonic foraminifer assemblages. Planktonic assemblages are dominated by tropical to warm subtropical species. The diatom community is highly diverse and resembles that of Site U1445. The diatom assemblage consists of species typical of warm to temperate, low- to mid-latitude ocean waters.

The age model for Site U1446 was established by combining calcareous nannofossil, planktonic foraminifer, and diatom datums with paleomagnetic reversal datums. The combined biostratigraphic/magnetostratigraphic age model indicates a mean sedimentation rate of $\sim 16 \mathrm{~cm} / \mathrm{ky}$ from $0 \mathrm{Ma}$ to just over $1 \mathrm{Ma}$. The oldest planktonic foraminifer datum encountered is the LO of Globorotalia tosaensis (0.61 Ma) in Sample 353-U1446A-12H-CC, whereas the combination of nannofossils and diatoms datums constrains the basal age of Hole U1446A to between 0.90 and 1.26 Ma.

\section{Geochemistry}

The organic C content of Site U1446 ranges from 0.8 to $1.6 \mathrm{wt} \%$ (average $=1.2 \mathrm{wt} \%$ ), and the geochemistry of the site mainly reflects the anaerobic processes of sulfate reduction and methanogenesis associated with microbial degradation of organic matter. Sulfate declines rapidly from $28 \mathrm{mM}$ at the sediment/water interface to near zero values at approximately $20 \mathrm{~m}$ CSF-A. Alkalinity peaks at $20 \mathrm{~m}$ depth, consistent with the production of bicarbonate during sulfate reduction. Sulfate reduction appears to continue throughout the core, as suggested by the gradual increase in dissolved Ba concentration with depth, as this $\mathrm{Ba}$ is likely derived from barite. Changes in the concentration of other cations and anions (Fe, Mg, Ca, ammonium, and $\mathrm{Sr}$ ) in pore waters can be readily explained by the microbial-induced chemical reactions and their effects on $\mathrm{pH}$, alkalinity, and mineral dissolution and precipitation. Headspace methane concentrations are generally low shallower than $30 \mathrm{~m}$ CSF-A but rise between 30 and $70 \mathrm{~m}$ CSF-A, peaking at $\sim 50 \mathrm{~m}$ CSF-A, with a moderate concentration of $1000 \mathrm{ppm}$. High methane to ethane ratios suggest that the methane is mostly of biogenic origin (methanogenesis). Carbonate content varies significantly between 2 and $20 \mathrm{wt} \%$ within the scale of a few meters, with the low content intervals corresponding to high NGR (terrestrial clay-rich materials).

\section{Paleomagnetism}

Paleomagnetic measurements were conducted on archive-half sections for all three holes at Site U1446, with AF demagnetization up to $10 \mathrm{mT}$. Discrete samples taken from working-half sections of Holes U1446A $(N=53)$ and U1446C $(N=9)$ were also analyzed, with AF demagnetization up to $40-80 \mathrm{mT}$. ChRMs of these discrete 
samples were calculated using the PCA technique. The paleomagnetic signal is generally good downhole to $\sim 120 \mathrm{~m}$ CSF-A, but data are highly scattered deeper. A magnetostratigraphy is constructed from 0 to $1.173 \mathrm{Ma}$ (to $170 \mathrm{~m} \mathrm{CSF}-\mathrm{A}$ ) in Hole U1446A, albeit with a certain degree of ambiguity for some of the chrons. In addition, anhysteretic remanent magnetization (ARM) was acquired and measured on a selection of discrete samples from Hole U1446A. A significant decrease in ARM as a consequence of diagenetic reduction at $30 \mathrm{~m}$ CSF-A was observed. ARM intensity increases slightly from 40 to $60 \mathrm{~m}$ CSF-A and decreases from 100 to $130 \mathrm{~m}$ CSF-A. These variations could relate to multiple factors, such as paleoproductivity, postdepositional alteration, or unseen lithologic variations, but unraveling these factors requires further exploration.

\section{Physical properties}

Downhole variations in physical property measurements at Site U1446 likely reflect changes in lithology, sedimentation rate, and diagenetic processes. Variation in physical properties as a function of depth at Site U1446 were not as significant as seen at other sites in this expedition. Only subtle changes in density and porosity were observed and formed the basis for dividing Hole U1446A into three PP subunits (1a-1c). Physical property data in Hole U1446C was very similar to Hole U1446A, and all the subunits could be identified. In both holes, cyclic variability in NGR values are interpreted to be reflecting changes in relative lithogenic and biogenic sedimentation.

\section{Stratigraphic correlation}

A composite scale (CCSF-A) and a splice were constructed for Site U1446 using MS, NGR, and RGB data from Holes U1446A and U1446C. Splicing among these holes enabled us to construct a continuous stratigraphic sequence to $\sim 108 \mathrm{~m} \mathrm{CCSF-D.} \mathrm{Because} \mathrm{of} \mathrm{data}$ quality and time availability issues, correlation should be viewed with caution deeper than $\sim 78 \mathrm{~m}$ CCSF-A.

\section{Highlights}

Site U1446 recovered $\sim 180 \mathrm{~m}$ of section from two holes, ranging from Middle Pleistocene to Holocene, with a mean sedimentation rate of $\sim 16 \mathrm{~cm} / \mathrm{ky}$. Hole U1446C recovered an excellent mudline, with common fragile epifaunal tubular agglutinated foraminifers. The entire interval was APC cored with excellent recovery. Toba ash (likely) was recovered at $\sim 15 \mathrm{~m}$ CSF-A. Although the site is within the hydrate stability zone and in the same general vicinity as Site U1445, no indications of hydrates were found, possibly due to the finer grained nature of the sediments. The spliced section at this site will yield an excellent continuous Late Pleistocene section. The high sedimentation rate offers excellent opportunities to reconstruct monsoon climates at suborbital to orbital timescales over the entire interval.

\section{Site U1447}

\section{Background and objectives}

Site U1447 is located in the Andaman Sea, $45 \mathrm{~km}$ offshore Little Andaman Island at 1392 mbsl (Figure F2). The site lies within a basin on the eastern flank of a rise that separates two north-southoriented basins structurally related to the Eastern Margin and Diligent faults penetrating upward from the underlying accretionary wedge complex. The location yields access to older sediments but is not protected from potential turbidite deposition. The objectives at this site were to recover Miocene to recent sediments in order to reconstruct changes in summer monsoon rainfall and runoff from the Irrawaddy and Salween Rivers as well as nearby Little Andaman Island at tectonic to suborbital timescales.

\section{Coring summary}

At Site U1447, Holes U1447A, U1447B, and U1447C were drilled to total depths of 738.0, 24.4, and $160.9 \mathrm{~m} \mathrm{DSF}$, respectively (Table T1). In Hole U1447A the APC, HLAPC, and XCB systems were deployed. In Holes U1447B and U1447C only the APC system was used. Overall, 108 cores were recorded for the site. A total of $451.27 \mathrm{~m}$ of core over a $444.3 \mathrm{~m}$ cored interval was recovered using the APC system (102\% recovery). The HLAPC cored interval was $67.8 \mathrm{~m}$ with a core recovery of $69.12 \mathrm{~m}(102 \%)$. The XCB cored interval was $409.2 \mathrm{~m}$ with a core recovery of $395.15 \mathrm{~m}(97 \%)$. The overall recovery percentage for Site U1447 was $99 \%$. The total time spent on Site U1447 was 6.13 days.

\section{Lithostratigraphy}

Sediments recovered from Holes U1447A, U1447B, and U1447C are principally composed of Late Pleistocene to late Miocene hemipelagic clays with a significant biogenic component and numerous turbidites (primarily calcitic turbidites), composing four distinct lithostratigraphic units (I-IV):

- Unit I (0-126.00 m CSF-A) is composed of Late Pleistocene greenish gray clayey nannofossil oozes with foraminifers and foraminifer-rich nannofossil oozes with clay.

- Unit II (126.00-329.12 m CSF-A) is composed of Late Pleistocene-late Pliocene greenish gray clayey nannofossil oozes with foraminifers, foraminifer-rich nannofossil oozes with clay, and clayey calcareous oozes with varying proportions of foraminifers. This unit is also characterized by the presence of numerous thin to thick light gray calcitic turbidites, described as foraminifer-rich and bioclastic-rich layers with authigenic carbonate and foraminifers dominated by the sand or silt size fraction.

- Unit III (329.12-489.80 m CSF-A) is composed of early Pliocene to late Miocene greenish gray clayey nannofossil oozes to calcareous oozes with varying amounts of glauconite.

- Unit IV (489.80-740.46 m CSF-A) is composed of late Miocene greenish gray-gray clayey nannofossil ooze with glauconite or biosilica, biosilica-rich clay with varying proportions of glauconite and nannofossils, and nannofossil-rich clay with biosilica.

The observed lithologic differences between the units are primarily the result of varying abundances of biosilica (principally diatoms and sponge spicules), turbidites, and nannofossils.

\section{Biostratigraphy}

Calcareous nannofossils are abundant or common throughout Hole U1447A. Their preservation is generally very good to moderate, except in two samples that contain poorly preserved, overgrown nannofossils. Foraminifers are dominant to abundant and very well preserved throughout the Pliocene-Pleistocene, with a few exceptions in the turbiditic interval of lithostratigraphic Unit II where preservation decreases to moderate or poor and/or abundance decreases to common. Foraminifers are dominant to abundant in most Miocene sediments as well, though abundance decreases to common or few in samples where diatom abundance is high. Preservation in the Miocene continues to be good with only two exceptions where moderate preservation accompanies low foraminifer abundances. Diatoms are sporadically present in the uppermost $566 \mathrm{~m}$ of Hole U1447A. Their abundance varies between abundant and few 
downcore. Valve preservation ranges from good to poor, and valves are better preserved in samples with abundances that are higher than common.

The frequency and distribution of nannofossil and foraminifer bioevents enabled the construction of a high-resolution age model for Site U1447. Diatoms were also useful for age estimation in samples deeper than $556.11 \mathrm{~m}$ CSF-A. Derived paleomagnetic reversal datums fit well into the biostratigraphic age model. The base of the Late Pleistocene was delineated by the LO of G. ruber (pink) at 32.25 $\mathrm{m}$ CSF-A. The Pliocene/Pleistocene boundary (2.59 Ma) is placed just below the LO of Discoaster pentaradiatus (2.39 Ma), which occurs between 299.78 and $301.89 \mathrm{~m}$ CSF-A. The Miocene/Pliocene boundary (5.33 Ma) occurs between 468.89 and $470.19 \mathrm{~m}$ CSF-A based on the $\mathrm{LO}$ of T. rugosus (5.28 Ma) and the $\mathrm{FO}$ of C. acutus (5.35 Ma) in this interval.

The oldest calcareous nannofossil sample studied contained Discoaster hamatus, suggesting an age older than $9.53 \mathrm{Ma}$. The oldest planktonic foraminifer datum encountered is the FO of Neogloboquadrina acostaensis (9.83 Ma), and combined with the presence of Globorotalia limbata in Sample 87X-CC, suggests that the basal age of Hole U1447A is between 9.83 and $10.66 \mathrm{Ma}$. The oldest diatom datum is the FO of Thalassiosira burckliana (between 719.87 and $721.31 \mathrm{~m}$ CSF-A), suggesting that the bottom of Hole U1447A is slightly older than $9.1 \mathrm{Ma}$. Based on linear fits, including all biostratigraphic and magnetostratigraphic data, sedimentation rates in Hole U1447A are highest in the Pleistocene (average $=12 \mathrm{~cm} / \mathrm{ky}$ linear sedimentation rate [LSR]), moderate in the Pliocene and most of the Miocene (average $=6.5 \mathrm{~cm} / \mathrm{ky} \mathrm{LSR}$ ), and possibly lower in the Miocene deeper than $700 \mathrm{~m}$ CSF-A.

\section{Geochemistry}

The geochemistry of Site U1447 mainly reflects the anaerobic processes of sulfate reduction and methanogenesis associated with microbial degradation of organic matter. The organic $\mathrm{C}$ content ranges from 0.1 to $2.0 \mathrm{wt} \%$ (average $=0.8 \mathrm{wt} \%$ ). Sulfate decreases rapidly from $28 \mathrm{mM}$ at the sediment/water interface to near zero values at approximately $20 \mathrm{~m}$ CSF-A. Alkalinity peaks at $20 \mathrm{~m}$ CSF-A, consistent with the production of bicarbonate during sulfate reduction. A gradual increase in dissolved $\mathrm{Ba}$ concentration with depth suggests ongoing barite dissolution. Changes in the concentration of other elements and ions (Fe, Mn, Ca, B, ammonium, and $\mathrm{Sr}$ ) in pore water can be readily explained by microbially mediated chemical reactions and their effects on $\mathrm{pH}$, alkalinity, and mineral dissolution and precipitation. Headspace methane concentrations peak at 125 m CSF-A, abruptly decrease below the peak, and are consistently low to the bottom of the hole. High methane to ethane ratios suggest that the methane is mostly of biogenic origin (methanogenesis). Carbonate content varies significantly between 9 and $55 \mathrm{wt} \%$.

\section{Paleomagnetism}

Paleomagnetic measurements were conducted on archive-half sections for all three holes at Site U1447, with AF demagnetization up to $10 \mathrm{mT}$. Discrete samples taken from working-half sections of Hole U1447A were also analyzed, with stepwise AF demagnetization up to 40-80 mT. ChRMs of these discrete samples were calculated using the PCA technique. Both types of data became noisy deeper than $\sim 90 \mathrm{~m}$ CSF-A, with a predominant drilling-related overprint. Two tentative magnetostratigraphies were proposed to at least $1.778 \mathrm{Ma}$ at $\sim 220 \mathrm{~m} \mathrm{CSF}-\mathrm{A}$ for Hole U1447A. These two classes use sets of data with different reliability from pass-through measurements and PCA directions. In addition, ARM was acquired and measured on a selection of Hole U1447A discrete samples for preliminary insight into depth variations in sediment bulk magnetic properties.

\section{Physical properties}

Downhole variations in physical property measurements at Site U1447 reflect changes in lithology, condensed sections associated with depositional hiatuses, and diagenetic processes. The overall suite of physical property data in Hole U1447A, which is the deepest hole, is divided into four broad PP units (1-4) based on significant transitions within the data. The depth of Holes U1447B and U1447C were not enough to use them for understanding hole-tohole physical property correlation. Overall, a long-term cyclic variability in NGR can be seen in Hole U1447A, which may be reflective of periodic changes in relative lithogenic and biogenic sedimentation.

\section{Stratigraphic correlation}

A composite scale (CCSF-A) and a splice were constructed for Site U1447 using MS, NGR, and RGB data from Holes U1447A and U1447C. Splicing among these holes enabled us to construct a continuous stratigraphic sequence to $\sim 147 \mathrm{~m}$ CCSF-D. Because of data quality and time availability issues, correlation should be viewed with caution deeper than $\sim 112$ m CCSF-A.

\section{Highlights}

Site U1447 exhibits a nearly complete hemipelagic succession from the recent (mudline with common fragile epifaunal tubular agglutinated foraminifers of the genera Rhabdammina and Saccorhiza) to middle Miocene ( $\sim 9.8 \mathrm{Ma})$, with all nannofossil biostratigraphic markers present.

Unconformities with possible short-term stratigraphic hiatuses in the upper part of the sedimentary succession include the following:

- A massive carbonate turbidite bed in the uppermost (Holocene) part of the succession at $\sim 1.40-2.4 \mathrm{~m}$ CSF-A.

- A hiatus at $\sim 290$ m CSF-A ( 2.17 s TWT on Line AN-01-25A) is indicated by the co-occurrence of several biostratigraphic events within the same stratigraphic interval. This unconformity may be associated with a prominent turbidite bed at interval 353U1447A-36F-1, $40 \mathrm{~cm}$, close to the Pliocene-Pleistocene transition.

- A second possible hiatus is indicated by a cluster of biostratigraphic events at $340 \mathrm{~m}$ CSF-A ( 2.23 s TWT on Line AN-01$25 \mathrm{~A})$ within the early-late Pliocene transition. The unconformity would be located within Core 46X, which had no recovery, where drilling progress indicated a noticeable change in lithology.

- A third possible hiatus is located at $470 \mathrm{~m}$ CSF-A ( 2.38 s TWT on Line AN-01-25A), within the Miocene-Pliocene transition (several nannoplankton events clustering around $5.35 \mathrm{Ma}$ datum) with the LO of Globoquadrina dehiscens (5.92 Ma) in Core $61 \mathrm{X}-\mathrm{CC}$ just below this interval. The sedimentary succession in this interval shows a distinct unconformity at the base of a distinct black layer at interval 60X-4, 70-73 cm.

These unconformities may be related to regional tectonic events; further investigation of their stratigraphic and regional extent will provide new insight into the Miocene-recent tectonic evolution of the Andaman accretionary wedge complex. 
The expanded stratigraphic section in Hole U1447A provides a first high-resolution record of late Miocene Indian monsoon variability in the Bay of Bengal. Shipboard investigations provided the first evidence for a link between monsoonal intensity and biosiliceous paleoproductivity patterns in the Andaman Sea over the last 9.8 My. All Pleistocene and most of the Pliocene sediments of Site U1447 are virtually barren of diatoms, which exhibit last common occurrences below the Miocene/Pliocene boundary. This temporal distribution pattern is distinctly different from the late Mioceneearly Pliocene "biogenic bloom" observed throughout the open tropical Indo-Pacific and Atlantic Oceans (e.g., Farrell et al., 1995; Dickens and Owen, 1999; Hermoyian and Owen, 2001). The maximum in diatom abundance in the Andaman area (roughly between 9.8 and $6.5 \mathrm{Ma}$ at Site U1447) together with an increase in authigenic pyrite and carbonate started earlier and was of shorter duration compared to the open-ocean biogenic bloom. These peculiar productivity changes within the Bay of Bengal could either reflect the availability of nutrients brought into the Bay of Bengal by rivers under a variable monsoonal intensity since the middle Miocene (Clift, 2006) or be related to the presence or absence of a seasonal freshwater lid, which would prevent upwelling of nutrient-rich intermediate waters during the monsoon season.

\section{Site U1448}

\section{Background and objectives}

Site U1448 (1097 mbsl) is located in the Andaman Sea, $44 \mathrm{~km}$ offshore Little Andaman Island, $17.7 \mathrm{~km}$ south of Site U1447 (Figure F2). The site lies atop a rise separating north-south-oriented basins associated with the Eastern Margin and Diligent faults, both related to the underlying accretionary wedge complex. The ridge-top location should have a lower sedimentation rate and be better protected from turbidite deposition. The objectives at this site are to recover Pliocene to recent sediments in order to reconstruct changes in summer monsoon rainfall and runoff from the Irrawaddy and Salween Rivers as well as nearby Little Andaman Island at tectonic to suborbital timescales.

\section{Coring summary}

At Site U1448, Holes U1448A, U1448B, and U1448C were drilled to total depths of 421.0, 358.6, and $34.3 \mathrm{~m} \mathrm{DSF}$, respectively (Table T1). In Hole U1448A the APC, HLAPC, and XCB systems were deployed. In Hole U1448B the APC and HLAPC systems were used, and only the APC system was deployed for Hole U1448C. Overall, 121 cores were recorded for the site. A total of $427.52 \mathrm{~m}$ of core over a $416.2 \mathrm{~m}$ cored interval was recovered using the APC system (103\% recovery). The HLAPC cored interval was $318.6 \mathrm{~m}$ with a core recovery of $333.24 \mathrm{~m}(105 \%)$. The XCB cored interval was $77.6 \mathrm{~m}$ with a core recovery of $78.21 \mathrm{~m}(101 \%)$. The overall recovery percentage for Site U1448 was 103\%. The total time spent on Site U1448 was 3.9 days.

\section{Lithostratigraphy}

Sediments recovered from Site U1448 are principally composed of hemipelagic clays with a significant biogenic component, composing four distinct lithostratigraphic units (I-IV) of Late Pleistocene to middle-early Miocene age:

- Unit I (0-183.11 m CSF-A) is composed of Late to early Pleistocene greenish gray clay with varying proportions of nannofossils and foraminifers, and clayey nannofossil ooze.

- Unit II (183.11-338.60 m CSF-A) is composed of early Pleistocene to late Miocene greenish clay with varying proportions of nannofossils and foraminifers, and characterized by a low biosilica content $(<1 \%)$.

- Unit III (338.60-379.11 m CSF-A) is composed of late Miocene greenish dark to light gray nannofossil-rich clay and clay with nannofossils, and characterized by the increased abundances of glauconite (up to $\sim 7 \%$ ) and siliceous sponge spicules (up to $\sim 4 \%)$. A hiatus representing $\sim 8$ My occurs at the base of Unit III at $379.11 \mathrm{~m} \mathrm{CSF-A,} \mathrm{where} \mathrm{there} \mathrm{is} \mathrm{an} \mathrm{abrupt} \mathrm{change} \mathrm{to} \mathrm{litho-}$ stratigraphic Unit IV.

- Unit IV (379.11-420.60 m CSF-A) is composed of middle-early Miocene greenish gray-light greenish gray biosiliceous ooze with varying proportions of clay and nannofossils.

The observed lithologic differences between the units are primarily the result of varying abundances of biogenic components (nannofossils, foraminifers, diatoms, and sponge spicules), clay, and glauconite.

\section{Biostratigraphy}

Calcareous nannofossils are abundant throughout Hole $\mathrm{U} 1448 \mathrm{~A}$, and their preservation is very good in the Pleistocene, Pliocene, and uppermost Miocene sediments (0-379.1 m CSF-A), with few reworked species. A hiatus was identified at $379.11 \mathrm{~m}$ CSF-A, separating late Miocene and middle Miocene sediments. Below the hiatus, nannofossils are abundant and moderately preserved. Nannofossil assemblages are typical of tropical/subtropical paleoenvironments. Foraminifers are well-preserved in all core catcher samples from Hole U1448A; they are dominant in the upper $340 \mathrm{~m}$, whereas their abundance decreases to common just above the hiatus and drops to few to common below the hiatus. Diatoms are rarely present in the uppermost $379.04 \mathrm{~m}$ of Hole U1448A. Their abundance abruptly increases just below the hiatus, and their preservation varies from moderate to good.

The age model for Site U1448 was established by combining calcareous nannofossil, planktonic foraminifer, and diatom datums (the latter below the hiatus only). The oldest calcareous nannofossil sample studied above the hiatus suggests an age between 5.94 and 6.91 Ma. Planktonic foraminifer datums constrain the age of the oldest core catcher sample above the hiatus to between 5.92 and 8.58 Ma. The three different microfossil groups suggest slightly different ages for the sediments below the hiatus. The interval between the hiatus and the bottom of Hole U1448A was constrained to between 14.91 and $17.71 \mathrm{Ma}$ based on nannofossils. The foraminifer assemblage in the youngest core catcher sample below the hiatus is older than $14.53 \mathrm{Ma}$, whereas the oldest planktonic foraminifer datum encountered is the LO of Praeorbulina glomerosa (14.78 Ma). The foraminifer P. glomerosa is found in the deepest sample (353U1448A-60X-CC), defining the basal age of Hole U1448A as 14.7816.27 Ma. Combining the ages of biostratigraphic events of nannofossil and planktonic foraminifers provides an estimate for the duration of the Miocene hiatus of approximately 8 My between 5.946.91 and 14.91-16.38 Ma. The co-occurrence of the diatom species Rhaphidodiscus marylandicus and Annellus californicus in the lowermost part of Hole U1448A suggests the bottom of Hole U1448A is older than $16.7 \mathrm{Ma}$ (LO of R. marylandicus) and younger than 17.3 $\mathrm{Ma}$ (FO of $A$. californicus).

Age-depth relationships for Hole U1448A based on biostratigraphy for the three fossil groups studied generally show good agreement. Sedimentation rates above the hiatus are between 5 and 6 $\mathrm{cm} / \mathrm{ky}$. Sedimentation rates below the hiatus are difficult to quantify given the wide range of estimated ages. 


\section{Geochemistry}

The geochemistry of Site U1448 mainly reflects the anaerobic processes of sulfate reduction and methanogenesis associated with microbial degradation of organic matter. The organic $\mathrm{C}$ content ranges from 0.2 to $1.4 \mathrm{wt} \%$ (average $=0.6 \mathrm{wt} \%$ ). Sulfate decreases from $28 \mathrm{mM}$ at the sediment/water interface to near zero values at approximately $40 \mathrm{~m}$ CSF-A. Alkalinity has a broad peak, significantly lower than at Site U1447, starting from $40 \mathrm{~m}$ to $150 \mathrm{~m}$ CSF-A before gradually decreasing, consistent with the production of bicarbonate during sulfate reduction. Headspace methane concentrations increase immediately below the sulfate interface and continue downcore with the highest values between 200 and $250 \mathrm{~m}$ CSF-A. The overall concentrations (20-30 ppmv), however, are quite low compared to Site U1447. High methane to ethane ratios suggest that the methane is mostly of biogenic origin (methanogenesis). A gradual increase in dissolved Ba concentration with depth suggests ongoing barite dissolution. Changes in the concentration of other elements and ions ( $\mathrm{Fe}, \mathrm{Mn}, \mathrm{Ca}, \mathrm{B}$, ammonium, and $\mathrm{Sr}$ ) in pore waters can be readily explained by microbially mediated chemical reactions and their effects on $\mathrm{pH}$, alkalinity, and mineral dissolution and precipitation. Carbonate content varies significantly between 12 and $37 \mathrm{wt} \%$.

\section{Paleomagnetism}

Paleomagnetic measurements were conducted on archive-half sections for all three holes at Site U1448. To accommodate the core flow, only APC and HLAPC cores from Hole U1448A were AF demagnetized up to $10 \mathrm{mT}$. XCB cores from Hole U1448A and APC cores from Holes U1448B and U1448C were measured predominantly for NRM, with a few exceptions. HLAPC cores from Hole U1448B have not been measured. Declination values from section measurements suggest the uppermost $200 \mathrm{~m}$ CSF-A is largely divided into three magnetozones, corresponding to the Brunhes (C1n), Matuyama (C1r), and Gauss (C2An) Chrons. Discrete samples taken from working-half sections of Hole U1448A $(N=90)$ were also analyzed, with stepwise AF demagnetization typically up to $80 \mathrm{mT}$, but generally the determination of ChRM was difficult likely due to drilling-related overprint. Stability of NRM appears to be high just below the hiatus (379.11 m CSF-A), with higher resolution measurements possibly inferring polarity transitions. ARM was acquired and measured on a selection of Hole U1448A discrete samples for preliminary insight into downcore variation in sediment bulk magnetic properties.

\section{Physical properties}

Downhole variations in physical property measurements at Site U1448 reflect changes in lithology, condensed sections associated with depositional hiatuses, and diagenetic processes. The overall suite of physical property data from Hole U1448A, which is the deepest hole, is divided into six broad PP units (1-6) based on significant transitions within the data. The top five units in Hole U1448A were based on subtle changes in the physical property trends rather than rapid transitions. The NGR data best show the long-term cyclicity at this site and are possibly related to variations in terrigenous input. Unit 1 shows high variability in almost all physical property measurements, likely from unconsolidated sediment. Unit 2 shows minor MS variability, increasing density, decreasing porosity, and relatively steady NGR counts. Unit 3 is characterized by an increase in MS, increase in density, increase in NGR counts, decrease in porosity, and lower b* values, suggesting higher terrigenous input and clay relative to carbonate or siliceous fractions. Unit 4 corresponds to lithostratigraphic Unit II. It has generally high MS values, high density, a continued decrease in porosity, variable NGR counts, and the lowest $b^{*}$ values. In Unit 5, MS, NGR, and density decrease, whereas porosity and $b^{*}$ increase. The physical properties of Unit 5 likely indicate an increase in abundance of more biosilica-rich clays. All physical property measure-

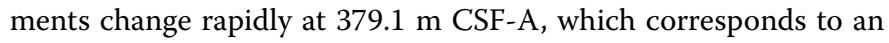
approximately 8 My hiatus. The top five units in Hole U1448A could be identified in Hole U1448B.

\section{Stratigraphic correlation}

A composite scale (CCSF-A) and a splice were constructed for Site U1448 using MS, NGR, and RGB data from Holes U1448A, $\mathrm{U} 1448 \mathrm{~B}$, and U1448C. Splicing among these holes enabled us to construct a continuous stratigraphic sequence to $\sim 203 \mathrm{~m}$ CCSF-D. Following a gap estimated to be $2 \mathrm{~m}$, a floating composite scale was constructed between $\sim 205$ and $\sim 260 \mathrm{~m}$ CCSF-A using Holes U1448A and U1448B. Because of data quality and time availability issues, correlation should be viewed with caution deeper than $\sim 115$ m CCSF-A.

\section{Highlights}

Hole U1448C recovered an excellent mudline, with common fragile epifaunal tubular agglutinated foraminifers. In contrast to the sedimentation at nearby Site U1447, the lower Pleistocene and middle-upper Pliocene at Site U1448 are not affected by gravity deposition (turbidites or fine-grained grain flows/debris flows). The lower Pleistocene and Pliocene of Site U1448 exhibit a complete hemipelagic succession with all calcareous biostratigraphic markers represented. The intermediate to high sedimentation rates of this succession $(5-6 \mathrm{~cm} / \mathrm{ky})$ will allow high-resolution paleoclimatic reconstructions using calcareous and organic proxy indicators of paleotemperature and salinity in a continuous succession reaching into the late Miocene (6.91 Ma).

The high-resolution sedimentary succession of Site U1448 also allowed recognition of a suite of volcanic tephra layers that appear at least partly correlative to the tephra succession of Site U1443. In particular, the tephra of the Late Pleistocene Toba eruption $(0.0738$ $\mathrm{Ma}$ ) could be recognized in all three holes of Site U1448 and provides an excellent marker bed for stratigraphic correlation.

The main highlight at Site U1448 was the recovery of pelagic middle Miocene sediment below the distinct seismic reflector at 1.865 s TWT on seismic Line AN01-26A (see Figure F3 in the Site U1448 chapter [Clemens et al., 2016]). The reflector represents a major unconformity between late Miocene (oldest biostratigraphic datum just above the unconformity is 6.91 Ma, LO of Reticulofenestra rotaria) and middle Miocene (14.53 Ma, LO of Praeorbulina sicana just below the unconformity). The middle Miocene pelagic succession below the unconformity comprises a carbonate-rich biosiliceous sedimentary succession that was fully recovered in very high quality XCB cores and will provide the first insight in monsoonal influenced biogenic sedimentation during the middle Miocene climatic optimum.

\section{Expedition 353 synthesis}

Six sites were drilled during Expedition 353 in the Bay of Bengal, recovering a total of $4280 \mathrm{~m}$ of sediment section during 32.9 days of on-site operations. One hole was logged. This is substantially less than the initially planned campaign targeting $6256 \mathrm{~m}$ of section, including downhole logging at three sites (Clemens et al., 2014). This 
difference amounts to approximately 15 days of lost operational time. Weather accounted for 1.6 days of lost operations. Mechanical breakdowns and broken coring equipment accounted for 1.98 days of lost operations. The remainder of the lost operational time was due to delays in attaining the necessary permissions to operate in Indian exclusive economic zone (EEZ) waters and to scheduling and conducting the necessary vessel inspections required to operate in Indian EEZ waters.

Operations at Site U1443 (NER) were scheduled to be three holes to $350 \mathrm{mbsf}$ with logging. This was largely accomplished with the exception of logging. Recovery was excellent, and triple coring produced the first complete spliced record of Neogene deepwater sediments in the Indian Ocean and a paleomagnetic reversal record spanning the lower Miocene and upper Oligocene. This will provide the opportunity for high-resolution climate reconstructions with solid chronostratigraphic control.

Bengal Fan Site U1444 was not targeted in the original operations plan of for Expedition 353. Drilling this site was necessary because it was in international waters and occupied a portion of the time during which negotiations over fees, duties, and inspection matters were ongoing. Nevertheless, this site will promote the scientific goals of Expedition 354. We successfully dated the Unconformities Uc and Ud defined in Schwenk and Spieß (2009). Preliminary results indicate that Unconformity Uc, within the error of dating, is the same age as found at Site 218, whereas Unconformity Ud may be considerably younger than the Site 218 unconformity initially hypothesized to be of the same age.

Operations at Site U1445, as planned, included two holes to 680 mbsf with logging. This was abbreviated to two holes spanning 672 and $305 \mathrm{~m}$ and logging. This site, located on the upper continental rise in the southern Mahanadi basin, although susceptible to turbidite and other gravity flow deposits, allowed recovery of lower Pleistocene to upper Miocene sediments that are not available at the other Mahanadi site (U1446). Recovery was a remarkable 99\% at this site, including $447 \mathrm{~m}$ of XCB coring. Loss of sediment because of gas expansion was minimized by using $8 \mathrm{~m}$ XCB advances, allowing $1.5 \mathrm{~m}$ of accommodation space within the core barrel. This site was the only site at which centimeter-scale cold spots were detected by infrared scanning of the core on the catwalk prior to sectioning. These intervals were documented to be related to gas hydrates by Rhizon pore water sampling, which revealed reduced chlorinity driven by gas hydrate disassociation.

Site U1446 is located on the continental slope within the Mahanadi basin on a northwest-southeast-trending ridge, effectively isolated from turbidite deposition. Operations here called for three holes to 184 mbsf. Loss of operational time resulted in an abbreviated plan, including two holes to the target depth. Both holes were accomplished with APC coring with more than 100\% recovery and excellent core quality. Recovered sediments spanned the past 1.2 My, including the initiation of high-amplitude Northern Hemisphere glaciation. Combined with sediments from Site U1445, reconstruction of monsoon climate change from the latest Miocene through recent is now possible for the first time in this important region.

Andaman Sea Sites U1447 and U1448 are 10 nmi apart but within different depositional settings. Site U1447 is located within a basin on the flank of a rise, susceptible to turbidite deposition but reaching back to the middle Miocene, whereas Site U1448 is on the top of the ridge, sheltered from turbidite deposition but reaching only into the late Miocene, where a hiatus transitions abruptly from $\sim 7$ to $\sim 14 \mathrm{Ma}$. Operations at Site U1447 initially targeted two deep holes to $738 \mathrm{~m}$ with downhole logging at one site. Restrictions on operational time reduced this site to one deep hole $(738 \mathrm{~m})$ and one shallow hole $(160 \mathrm{~m})$ with no logging. Similarly, operations at Site U1448 called for three holes to $422 \mathrm{~m}$. This plan was truncated to two holes, one to target depth and the other to $356 \mathrm{~m}$. These Andaman Sea sites allow for the first time reconstruction of monsoonal climates from late Miocene to present in this region.

\section{Expedition 353 science assessment}

\section{Drilling operations-core handling}

Drilling operations and core handling were performed absolutely professionally and with outstanding commitment. Results were accordingly extraordinary (i.e., full-recovery APC coring to more than 350 mbsf in two holes and complete APC records to the early Oligocene at Site U1443, where previous APC coring terminated within the Pleistocene). In the cases of technical issues or sediment issues such as degassing within the core barrel, appropriate drilling and core handling adjustments were implemented rapidly, preserving the quality of the cored sections. Overall, the outstanding skills of the drillers and core technicians were the main reason why, despite significant scheduling setbacks, the scientific goals of Expedition 353 were able to be accomplished.

\section{Critical aspects}

\section{Physical property data quality and stratigraphic correlation}

Relatively poor data quality of MS (Section Half Multisensor Logger [SHMSL]), NGR, and color reflectance measurements (SHMSL), as well as muted physical properties signals made it difficult to create reliable splices at sea for crucial parts of the records recovered during Expedition 353. In particular, sections that were cored using the HLAPC, which were of outstanding quality, could not be correlated with sufficient precision because of the lack of detail in the physical property data. This stemmed from two factors, the primary being the extremely noisy SHMSL data associated with the inability of the instrument to land the MS and spectral sensors flush on the core surface; it is possible that these measurements may simply have to be done by hand in order to attain reliable data. The other contributing factor is specific to the sediments recovered. In many cases, the MS signal of the sediment was low because diagenetic factors and color variation within sediments was muted. Even so, the only data set that proved of reliable quality and sufficient resolution was the line scan RGB data. These data, however, cannot stand alone as the only data available for creating reliable splices at sea. A possible solution to this dilemma in the future would be to install a shipboard X-ray fluorescence (XRF) scanning facility. This would reliably compensate for low MS and color variability and greatly enhance the lithologic description available at sea.

To overcome significant problems with high-resolution sampling plans for Expedition 353, several core sections are being sent to the Woods Hole Oceanographic Institute and to the Bremen Core Repository for XRF core scanning. The core scanning results will be used to extend the reliable stratigraphic splices created on the ship prior to the sampling party at the Kochi Core Center.

\section{Administrative preparation for operations within Indian EEZ waters}

During Expedition 353, $4280 \mathrm{~m}$ of sediment section was recovered during 32.9 days of on-site operations. One hole was logged. 
As initially planned, the expedition targeted $6256 \mathrm{~m}$ of recovery and three logged holes (Clemens et al., 2014). The lost logging and nearly $2000 \mathrm{~m}$ of unrecovered sediment section are accounted for by close to 15 days of lost operational time. Weather accounted for 1.6 days of lost operations. Mechanical breakdowns, four broken core barrels, rusted winch wire, and parting of the winch wire accounted for 1.98 days of lost operations. This lost time can be largely attributed to the hazards of working in difficult environments.

The large majority of the lost operational time was due to delays in attaining the necessary permissions to operate in Indian EEZ waters, scheduling and conducting the vessel inspections required to operate in Indian EEZ waters, and protracted negotiations over concern that the JOIDES Resolution would incur excessive fees/duties upon entering port for inspection. These issues are typically addressed and resolved prior to an expedition and would not normally impact operational time. Expedition 353 had to compensate by cutting two of the three planned logging operations, canceling one primary site in the Mahanadi basin entirely, and canceling or shortening additional holes required to ensure complete spliced records to full target depths in the Mahanadi basin and Andaman Sea. Fortunately, formation characteristics and sea state worked strongly in our favor to produce excellent (near 100\%) recovery, even in XCB cored intervals. This will serve to reduce the negative impact of lost operational time.

\section{References}

Akhil, V.P., Durand, F., Lengaigne, M., Vialard, J., Keerthi, M.G., Gopalakrishna, V.V., Deltel, C., Papa, F., and de Boyer Montégut, C., 2014. A modeling study of the processes of surface salinity seasonal cycle in the Bay of Bengal. Journal of Geophysical Research: Oceans, 119(6):39263947. http://dx.doi.org/10.1002/2013JC009632

Ali, S., Hathorne, E.C., Frank, M., Gebregiorgis, D., Stattegger, K., Stumpf, R., Kutterolf, S., Johnson, J.E., and Giosan, L., 2015. South Asian monsoon history over the past $60 \mathrm{kyr}$ recorded by radiogenic isotopes and clay mineral assemblages in the Andaman Sea. Geochemistry, Geophysics, Geosystems, 16(2):505-521. http://dx.doi.org/10.1002/2014GC005586

Altabet, M.A., Higginson, M.J., and Murray, D.W., 2002. The effect of millennial-scale changes in Arabian Sea denitrification on atmospheric $\mathrm{CO}_{2}$. Nature, 415(6868):159-162. http://dx.doi.org/10.1038/415159a

An, Z., Clemens, S.C., Shen, J., Qiang, X., Jin, Z., Sun, Y., Prell, W.L., Luo, J., Wang, S., Xu, H., Cai, Y., Zhou, W., Liu, X., Liu, W., Shi, Z., Yan, L., Xiao, X., Chang, H., Wu, F., Ai, L., and Lu, F., 2011. Glacial-interglacial Indian summer monsoon dynamics. Science, 333(6043):719-723. http://dx.doi.org/10.1126/science.1203752

Anand, P., Kroon, D., Singh, A.D., Ganeshram, R.S., Ganssen, G., and Elderfield, H., 2008. Coupled sea surface temperature-seawater $\delta^{18} \mathrm{O}$ reconstructions in the Arabian Sea at the millennial scale for the last $35 \mathrm{ka}$. Paleoceanography, 23(4):PA4207. http://dx.doi.org/10.1029/2007PA001564

Antonov, J.I., Seidov, D., Boyer, T.P., Locarnini, R.A., Mishonov, A.V., Garcia, H.E., Baranova, O.K., Zweng, M.M., and Johnson, D.R., 2010. World Ocean Atlas 2009 (Volume 2): Salinity. In Levitus, S. (Ed.), NOAA Atlas NESDIS 69: Washington D.C. (U.S. Government Printing Office). ftp://ftp.nodc.noaa.gov/pub/WOA09/DOC/woa09_vol2_text_figures.pdf

Balmaseda, M.A., Mogensen, K., and Weaver, A.T., 2012. Evaluation of the ECMWF ocean reanalysis system ORAS4. Quarterly Journal of the Royal Meteorological Society, 139(674):1132-1161. http://dx.doi.org/10.1002/qj.2063

Bemis, B.E., Spero, H.J., Bijma, J., and Lea, D.W., 1998. Reevaluation of the oxygen isotopic composition of planktonic foraminifera: experimental results and revised paleotemperature equations. Paleoceanography, 13(2):150-160. http://dx.doi.org/10.1029/98PA00070
Bolton, C.T., Chang, L., Clemens, S.C., Kodama, K., Ikehara, M., Medina-Elizalde, M., Paterson, G.A., Roberts, A.P., Rohling, E.J., Yamamoto, Y., and Zhao, X., 2013. A 500,000 year record of Indian summer monsoon dynamics recorded by eastern equatorial Indian Ocean upper water-column structure. Quaternary Science Reviews, 77:167-180. http://dx.doi.org/10.1016/j.quascirev.2013.07.031

Bosilovich, M.G., and Schubert, S.D., 2002. Water vapor tracers as diagnostics of the regional hydrologic cycle. Journal of Hydrometeorology, 3(2):149165. http://dx.doi.org/10.1175/1525754.1(2002)003<0149:WVTADO >2.0.CO;2

Burton, K.W., Gannoun, A., and Parkinson, I.J., 2010. Climate driven glacialinterglacial variations in the osmium isotope composition of seawater recorded by planktic foraminifera. Earth and Planetary Science Letters, 295(1-2):58-68. http://dx.doi.org/10.1016/j.epsl.2010.03.026

Burton, K.W., and Vance, D., 2000. Glacial-interglacial variations in the neodymium isotope composition of seawater in the Bay of Bengal recorded by planktonic foraminifera. Earth and Planetary Science Letters, 176(34):425-441. http://dx.doi.org/10.1016/S0012-821X(00)00011-X

Caballero-Gill, R.P., Clemens, S.C., and Prell, W.L., 2012. Direct correlation of Chinese speleothem $\delta^{18} \mathrm{O}$ and South China Sea planktonic $\delta^{18} \mathrm{O}$ : transferring a speleothem chronology to the benthic marine chronology. Paleoceanography, 27(2):PA2203. http://dx.doi.org/10.1029/2011PA002268

Cai, Y., An, Z., Cheng, H., Edwards, R.L., Kelly, M.J., Liu, W., Wang, X., and Shen, C.-C., 2006. High-resolution absolute-dated Indian Monsoon record between 53 and 36 ka from Xiaobailong Cave, southwestern China. Geology, 34(8):621-624. http://dx.doi.org/10.1130/G22567.1

Caley, T., Malaizé, B., Bassinot, F., Clemens, S.C., Caillon, N., Linda, R., Charlier, K., and Rebaubier, H., 2011a. The monsoon imprint during the "atypical" MIS 13 as seen through north and equatorial Indian Ocean records. Quaternary Research, 76(2):285-293.

http://dx.doi.org/10.1016/j.yqres.2011.07.001

Caley, T., Malaizé, B., Revel, M., Ducassou, E., Wainer, K., Ibrahim, M., Shoeaib, D., Migeon, S., and Marieu, V., 2011b. Orbital timing of the Indian, East Asian and African boreal monsoons and the concept of a 'global monsoon'. Quaternary Science Reviews, 30(25-26):3705-3715. http://dx.doi.org/10.1016/j.quascirev.2011.09.015

Caley, T., Malaizé, B., Zaragosi, S., Rossignol, L., Bourget, J., Eynaud, F., Martinez, P., Giraudeau, J., Charlier, K., and Ellouz-Zimmermann, N., 2011c. New Arabian Sea records help decipher orbital timing of Indo-Asian monsoon. Earth and Planetary Science Letters, 308(3-4):433-444. http://dx.doi.org/10.1016/j.epsl.2011.06.019

Cane, M.A., and Molnar, P., 2001. Closing of the Indonesian Seaway as a precursor to East African aridification around 3-4 million years ago. Nature, 411(6834):157-162. http://dx.doi.org/10.1038/35075500

Cawthern, T., Johnson, J.E., Giosan, L., Flores, J.A., Rose, K., and Solomon, E., 2014. A late Miocene-early Pliocene biogenic silica crash in the Andaman Sea and Bay of Bengal. Marine and Petroleum Geology, 58(Part A):490501. http://dx.doi.org/10.1016/j.marpetgeo.2014.07.026

Cerling, T.E., Harris, J.M., MacFadden, B.J., Leakey, M.G., Quade, J., Eisenmann, V., and Ehleringer, J.R., 1997. Global vegetation change through the Miocene/Pliocene boundary. Nature, 389(6647):153-158. http://dx.doi.org/10.1038/38229

Cheng, H., Edwards, R.L., Broecker, W.S., Denton, G.H., Kong, X., Wang, Y., Zhang, R., and Wang, X., 2009. Ice age terminations. Science, 326(5950):248-252. http://dx.doi.org/10.1126/science.1177840

Chesner, C.A., and Rose, W.I., 1991. Stratigraphy of the Toba tuffs and the evolution of the Toba caldera complex, Sumatra, Indonesia. Bulletin of Volcanology, 53(5):343-356. http://dx.doi.org/10.1007/BF00280226

Clemens, S.C., 2005. Millennial-band climate spectrum resolved and linked to centennial-scale solar cycles. Quaternary Science Reviews, 24(5-6):521531. http://dx.doi.org/10.1016/j.quascirev.2004.10.015

Clemens, S.C., Kuhnt, W., and LeVay, L.J., 2014. Expedition 353 Scientific Prospectus: iMonsoon. International Ocean Discovery Program. http://dx.doi.org/10.14379/iodp.sp.353.2014

Clemens, S.C., Kuhnt, W., LeVay, L.J., Anand, P., Ando, T., Bartol, M., Bolton, C.T., Ding, X., Gariboldi, K., Giosan, L., Hathorne, E.C., Huang, Y., Jaiswal, P., Kim, S., Kirkpatrick, J.B., Littler, K., Marino, G., Martinez, P., 
Naik, D., Peketi, A., Phillips, S.C., Robinson, M.M., Romero, O.E., Sagar, N., Taladay, K.B., Taylor, S.N., Thirumalai, K., Uramoto, G., Usui, Y., Wang, J., Yamamoto, M., and Zhou, L., 2016. Site U1448. In Clemens, S.C., Kuhnt, W., LeVay, L.J., and the Expedition 353 Scientists, Indian Monsoon Rainfall. Proceedings of the International Ocean Discovery Program, 353: College Station, TX (International Ocean Discovery Program). http://dx.doi.org/10.14379/iodp.proc.353.108.2016

Clemens, S.C., Murray, D.W., and Prell, W.L., 1996. Nonstationary phase of the Plio-Pleistocene Asian monsoon. Science, 274(5289):943-948. http://dx.doi.org/10.1126/science.274.5289.943

Clemens, S.C., and Prell, W.L., 2003. A 350,000 year summer-monsoon multiproxy stack from the Owen Ridge, northern Arabian Sea. Marine Geology, 201(1-3):35-51. http://dx.doi.org/10.1016/S0025-3227(03)00207-X

Clemens, S.C., and Prell, W.L., 2007. The timing of orbital-scale Indian monsoon changes. Quaternary Science Reviews, 26(3-4):275-278. http://dx.doi.org/10.1016/j.quascirev.2006.11.010

Clemens, S.C., Prell, W., Murray, D., Shimmield, G., and Weedon, G., 1991. Forcing mechanisms of the Indian Ocean monsoon. Nature, 353(6346):720-725. http://dx.doi.org/10.1038/353720a0

Clemens, S.C., Prell, W.L., and Sun, Y., 2010. Orbital-scale timing and mechanisms driving Late Pleistocene Indo-Asian summer monsoons: reinterpreting cave speleothem $\delta^{18} \mathrm{O}$. Paleoceanography, 25(4):PA4207. http://dx.doi.org/10.1029/2010PA001926

Clemens, S.C., Prell, W.L., Sun, Y., Liu, Z., and Chen, G., 2008. Southern Hemisphere forcing of Pliocene $\delta^{18} \mathrm{O}$ and the evolution of Indo-Asian monsoons. Paleoceanography, 23(4):PA4210. http://dx.doi.org/10.1029/2008PA001638

Clift, P.D., 2006. Controls on the erosion of Cenozoic Asia and the flux of clastic sediment to the ocean. Earth and Planetary Science Letters, 241(34):571-580. http://dx.doi.org/10.1016/j.epsl.2005.11.028

Clift, P.D., Hodges, K.V., Heslop, D., Hannigan, R., Long, H.V., and Calves, G., 2008. Correlation of Himalayan exhumation rates and Asian monsoon intensity. Nature Geoscience, 1(12):875-880. http://dx.doi.org/10.1038/ngeo351

Clift, P.D., and Plumb, R.A., 2008. The Asian Monsoon: Causes, History and Effects: Cambridge, United Kingdom (Cambridge University Press). http://dx.doi.org/10.1017/CBO9780511535833

Colin, C., Kissel, C., Blamart, D., and Turpin, L., 1998. Magnetic properties of sediments in the Bay of Bengal and the Andaman Sea: impact of rapid North Atlantic Ocean climatic events on the strength of the Indian monsoon. Earth and Planetary Science Letters, 160(3-4):623-635. http://dx.doi.org/10.1016/S0012-821X(98)00116-2

Collett, T.S., Riedel, M., Cochran, J., Boswell, R., Presley, J., Kumar, P., Sathe, A.V., Sethi, A., Lall, M., Sibal, V., and the NGHP Expedition 01 Scientists, 2008. Indian National Gas Hydrate Program (NGHP) Expedition 01, Initial Report: Noida, India (DGH, Ministry of Petroleum and Natural Gas).

Cullen, J.L., and Prell, W.L., 1984. Planktonic foraminifera of the northern Indian Ocean: distribution and preservation in surface sediments. Marine Micropaleontology, 9(1):1-52. http://dx.doi.org/10.1016/0377-8398(84)90022-7

Curray, J.R., 1991. Possible greenschist metamorphism at the base of a 22-km sedimentary section, Bay of Bengal. Geology, 19(11):1097-1100. http://dx.doi.org/10.1130/00917613(1991)019<1097:PGMATB > 2.3.CO;2

Dehn, J., Farrell, J.W., and Schmincke, H.-U., 1991. Neogene tephrochronology from Site 758 on northern Ninetyeast Ridge: Indonesian arc volcanism of the past 5 Ma. In Weissel, J., Peirce, J., Taylor, E., Alt, J., et al., Proceedings of the Ocean Drilling Program, Scientific Results, 121: College Station, TX (Ocean Drilling Program), 273-295. http://dx.doi.org/10.2973/odp.proc.sr.121.123.1991

Dettman, D.L., Kohn, M.J., Quade, J., Ryerson, F.J., Ojha, T.P., and Hamidullah, S., 2001. Seasonal stable isotope evidence for a strong Asian monsoon throughout the past 10.7 m.y. Geology, 29(1):31-34.

http://dx.doi.org/10.1130/0091-

7613(2001)029<0031:SSIEFA >2.0.CO;2
Dickens, G.R., and Owen, R.M., 1999. The latest Miocene-early Pliocene biogenic bloom: a revised Indian Ocean perspective. Marine Geology, 161(1):75-91. http://dx.doi.org/10.1016/S0025-3227(99)00057-2

Ding, Y., and Chan, J.C.L., 2005. The East Asian summer monsoon: an overview. Meteorology and Atmospheric Physics, 89(1-4):117-142. http://dx.doi.org/10.1007/s00703-005-0125-z

Ding, Y., Li, C., and Liu, Y., 2004. Overview of the South China Sea monsoon experiment. Advances in Atmospheric Sciences, 21(3):343-360. http://dx.doi.org/10.1007/BF02915563

Emile-Geay, J., Cane, M.A., Naik, N., Seager, R., Clement, A.C., and van Geen, A., 2003. Warren revisited: atmospheric freshwater fluxes and "why is no deep water formed in the North Pacific?" Journal of Geophysical Research: Oceans, 108(C6):3178. http://dx.doi.org/10.1029/2001JC001058

Emmel, F.J., and Curray, J.R., 1984. Bengal Fan, Indian Ocean. In Bouma, A.H., Normark, W.P., and Barnes, N.E. (Eds.), Submarine Fans and Related Systems: New York (Springer-Verlag), 248-275.

Farrell, J.W., and Janecek, T.R., 1991. Late Neogene paleoceanography and paleoclimatology of the northeast Indian Ocean (Site 758). In Weissel, J., Peirce, J., Taylor, E., Alt, J., et al., Proceedings of the Ocean Drilling Program, Scientific Results, 121: College Station, TX (Ocean Drilling Program), 297-355. http://dx.doi.org/10.2973/odp.proc.sr.121.124.1991

Farrell, J.W., Raffi, I., Janecek, T.R., Murray, D.W., Levitan, M., Dadey, K.A., Emeis, K.-C., Lyle, M., Flores, J.-A., and Hovan, S., 1995. Late Neogene sedimentation patterns in the eastern equatorial Pacific Ocean. In Pisias, N.G., Mayer, L.A., Janecek, T.R., Palmer-Julson, A., and van Andel, T.H. (Eds.), Proceedings of the Ocean Drilling Program, Scientific Results, 138: College Station, TX (Ocean Drilling Program), 717-756. http://dx.doi.org/10.2973/odp.proc.sr.138.143.1995

Federov, L.V., Ravich, M.G., and Hofmann, J., 1982. Geologic comparison of southeastern peninsular India and Sri Lanka with a part of East Antarctica (Enderby Land, MacRobertson Land, and Princess Elizabeth Land). In Craddock, C. (Ed.), Antarctic Geoscience: Madison, WI (University of Wisconsin Press), 73-78.

Flores, J.A., Johnson, J.E., Mejía-Molina, A.E., Álverez, M.C., Sierro, F.J., Singh, S.D., Mahanti, S., and Giosan, L., 2014. Sedimentation rates from calcareous nannofossil and planktonic foraminifera biostratigraphy in the Andaman Sea, northern Bay of Bengal, and eastern Arabian Sea. Marine and Petroleum Geology, 58(Part A):425-437. http://dx.doi.org/10.1016/j.marpetgeo.2014.08.011

France-Lanord, C., Schwenk, T., and Klaus, A., 2014. Expedition 354 Scientific Prospectus: Bengal Fan. International Ocean Discovery Program. http://dx.doi.org/10.14379/iodp.sp.354.2014

Frank, M., Whiteley, N., van de Flierdt, T., Reynolds, B.C., and O’Nions, K., 2006. $\mathrm{Nd}$ and $\mathrm{Pb}$ isotope evolution of deep water masses in the eastern Indian Ocean during the past 33 Myr. Chemical Geology, 226(3-4):264279. http://dx.doi.org/10.1016/j.chemgeo.2005.09.024

Frerichs, W.E., 1971. Planktonic foraminifera in the sediments of the Andaman Sea. Journal of Foraminiferal Research, 1(1):1-14. http://dx.doi.org/10.2113/gsjfr.1.1.1

Gourlan, A.T., Meynadier, L., and Allègre, C.J., 2008. Tectonically driven changes in the Indian Ocean circulation over the last $25 \mathrm{Ma}$ : neodymium isotope evidence. Earth and Planetary Science Letters, 267(1-2):353-364. http://dx.doi.org/10.1016/j.epsl.2007.11.054

Gourlan, A.T., Meynadier, L., Allègre, C.J., Tapponnier, P., Birck, J.-L., and Joron, J.-L., 2010. Northern Hemisphere climate control of the Bengali rivers discharge during the past $4 \mathrm{Ma}$. Quaternary Science Reviews, 29(19-20):2484-2498. http://dx.doi.org/10.1016/j.quascirev.2010.05.003

Guo, Z.T., Ruddiman, W.F., Hao, Q.Z., Wu, H.B., Qiao, Y.S., Zhu, R.X., Peng, S.Z., Wei, J.J., Yuan, B.Y., and Liu, T.S., 2002. Onset of Asian desertification by $22 \mathrm{Myr}$ ago inferred from loess deposits in China. Nature, 416(6877):159-163. http://dx.doi.org/10.1038/416159a

Gupta, A.K., Singh, R.K., Joseph, S., and Thomas, E., 2004. Indian Ocean high-productivity event (10-8 Ma): linked to global cooling or to the initiation of the Indian monsoons? Geology, 32(9):753-756. http://dx.doi.org/10.1130/G20662.1 
Gupta, A.K., Singh, R.K., and Verma, S., 2013. Deep-sea palaeoceanographic evolution of the eastern Indian Ocean during the late Oligocene-Pleistocene: species diversity trends in benthic foraminifera. Current Science, 104.(7):904-910. http://www.currentscience.ac.in/Volumes/104/07/0904.pdf

Gupta, A.K., and Thomas, E., 2003. Initiation of Northern Hemisphere glaciation and strengthening of the northeast Indian monsoon: Ocean Drilling Program Site 758, eastern equatorial Indian Ocean. Geology, 31(1):47-50. http://dx.doi.org/10.1130/0091-7613(2003)031<0047:ION$\mathrm{HGA}>2.0 . \mathrm{CO} ; 2$

Guptha, M.V.S., Curry, W.B., Ittekkot, V., and Muralinath, A.S., 1997. Seasonal variation in the flux of planktonic foraminifera: sediment trap results from the Bay of Bengal, northern Indian Ocean. Journal of Foraminiferal Research, 27(1):5-19. http://dx.doi.org/10.2113/gsjfr.27.1.5

Hall, C.M., and Farrell, J.W., 1993. Laser ${ }^{40} \mathrm{Ar} /{ }^{39} \mathrm{Ar}$ age from Ash D of ODP Site 758: dating the Brunhes-Matuyama reversal and oxygen isotope Stage 19.1. Eos, Transactions of the American Geophysical Union, 74(Supplement):110.

Hall, C.M., and Farrell, J.W., 1995. Laser ${ }^{40} \mathrm{Ar} /{ }^{39} \mathrm{Ar}$ ages of tephra from Indian Ocean deep-sea sediments: tie points for the astronomical and geomagnetic polarity time scales. Earth and Planetary Science Letters, 133(34):327-338. http://dx.doi.org/10.1016/0012-821X(95)00087-S

Hall, R., 2002. Cenozoic geological and plate tectonic evolution of SE Asia and the SW Pacific: computer-based reconstructions, model and animations. Journal of Asian Earth Sciences, 20(4):353-431. http://dx.doi.org/10.1016/S1367-9120(01)00069-4

Hall, R., Cottam, M.A., and Wilson, M.E.J., 2011. The SE Asian Gateway: History and Tectonics of the Australia-Asia Collision. Special Publication Geological Society of London, 355. http://dx.doi.org/10.1144/SP355.1

Hastenrath, S., and Greischar, L., 1993. The monsoonal heat budget of the hydrosphere atmosphere system in the Indian Ocean sector. Journal of Geophysical Research: Oceans, 98(C4):6869-6881. http://dx.doi.org/10.1029/92JC02956

Hermoyian, C.S., and Owen, R.M., 2001. Late Miocene-early Pliocene biogenic bloom: evidence from low-productivity regions of the Indian and Atlantic Oceans. Paleoceanography, 16(1):95-100. http://dx.doi.org/10.1029/2000PA000501

Holbourn, A., Kuhnt, W., Clemens, S., Prell, W., and Andersen, N., 2013. Middle to late Miocene stepwise climate cooling: evidence from a high-resolution deep water isotope curve spanning 8 million years.

Paleoceanography, 28(4):688-699. http://dx.doi.org/10.1002/2013PA002538

Holbourn, A., Kuhnt, W., Kochhann, K.G.D., Andersen, N., and Meier, S., 2015. Global perturbation of the carbon cycle at the onset of the Miocene Climatic Optimum. Geology, 43(2):123-126. http://dx.doi.org/10.1130/G36317.1

Holbourn, A., Kuhnt, W., Lyle, M., Schneider, L., Romero, O., and Anderson, N., 2013. Middle Miocene climate cooling linked to intensification of eastern equatorial Pacific upwelling. Geology, 42(1):19-22. http://dx.doi.org/10.1130/G34890.1

Holbourn, A., Kuhnt, W., Schulz, M., Flores, J.-A., and Andersen, N., 2007. Orbitally-paced climate evolution during the middle Miocene "Monterey" carbon-isotope excursion. Earth and Planetary Science Letters, 261(3-4):534-550. http://dx.doi.org/10.1016/j.epsl.2007.07.026

Hoogakker, B.A.A., Rohling, E.J., Palmer, M.R., Tyrrell, T., and Rothwell, R.G., 2006. Underlying causes for long-term global ocean $\delta^{13} \mathrm{C}$ fluctuations over the last 1.20 Myr. Earth and Planetary Science Letters, 248(1-2):15-29. http://dx.doi.org/10.1016/j.epsl.2006.05.007

Hovan, S., and Rea, D.K., 1992. The Cenozoic record of continental mineral deposition on Broken and Ninetyeast Ridges, Indian Ocean: southern African aridity and sediment delivery from the Himalayas. Paleoceanography, 7(6):833-860. http://dx.doi.org/10.1029/92PA02176

Huang, Y., Clemens, S.C., Liu, W., Wang, Y., and Prell, W.L., 2007. Large-scale hydrological change drove the late Miocene $\mathrm{C}_{4}$ plant expansion in the Himalayan foreland and Arabian Peninsula. Geology, 35(6):531-534. http://dx.doi.org/10.1130/G23666A.1
Jensen, T.G., 2001. Arabian Sea and Bay of Bengal exchange of salt and tracers in an ocean model. Geophysical Research Letters, 28(20):3967-3970. http://dx.doi.org/10.1029/2001GL013422

Jensen, T.G., 2003. Cross-equatorial pathways of salt and tracers from the northern Indian Ocean: modeling results. Deep Sea Research, Part II, 50(12-13):2111-2127.

http://dx.doi.org/10.1016/S0967-0645(03)00048-1

Johnson, J.E., Phillips, S.C., Torres, M.E., Piñero, E., Rose, K.K., and Giosan, L., 2014. Influence of total organic carbon deposition on the inventory of gas hydrate in the Indian continental margins. Marine and Petroleum Geology, 58(Part A):406-424.

http://dx.doi.org/10.1016/j.marpetgeo.2014.08.021

Kroon, D., Steens, T., and Troelstra, S.R., 1991. Onset of monsoonal related upwelling in the western Arabian Sea as revealed by planktonic foraminifers. In Prell, W.L., Niitsuma, N., et al., Proceedings of the Ocean Drilling Program, Scientific Results, 117: College Station, TX (Ocean Drilling Program), 257-263. http://dx.doi.org/10.2973/odp.proc.sr.117.126.1991

Kuhnt, W., Holbourn, A., Hall, R., Zuvela, M., and Käse, R., 2004. Neogene history of the Indonesian Throughflow. In Clift, P., Wang, P., Kuhnt, W., and Hayes, D. (Eds.), Continent-Ocean Interactions within East Asian Marginal Seas. Geophysical Monograph, 149:299-320.

http://dx.doi.org/10.1029/149GM16

Kumar, S.P., Muraleedharan, P.M., Prasad, T.G., Gauns, M., Ramaiah, N., de Souza, S.N., Sardesai, S., and Madhupratap, M., 2002. Why is the Bay of Bengal less productive during summer monsoon compared to the Arabian Sea? Geophysical Research Letters, 29(24):2235.

http://dx.doi.org/10.1029/2002GL016013

Le Houedec, S., Meynadier, L., Cogné, J.-P., Allègre, C.J., and Gourlan, A.T., 2012. Oceanwide imprint of large tectonic and oceanic events on seawater Nd isotope composition in the Indian Ocean from 90 to $40 \mathrm{Ma}$. Geochemistry, Geophysics, Geosystems, 13(6):Q06008. http://dx.doi.org/10.1029/2011GC003963

Licht, A., van Cappelle, M., Abels, H.A., Ladant, J.-B., Trabucho-Alexandre, J., France-Lanord, C., Donnadieu, Y., Vandenberghe, J., Rigaudier, T., Lécuyer, C., Terry, D., Jr., Adriaens, R., Boura, A., Guo, Z., Soe, A.N., Quade, J., Dupont-Nivet, G., and Jaeger, J.-J., 2014. Asian monsoons in a late Eocene greenhouse world. Nature, 513(7519):501-506. http://dx.doi.org/10.1038/nature13704

Liu, W.T., and Tang, W., 2004. Oceanic influence on the precipitation in India and China as observed by TRMM and QuikSCAT [paper presented at 2nd TRMM International Science Conference, Nara, Japan, 6-10 September 2004]. http://www.eorc.jaxa.jp/TRMM/museum/event/2ndTISC/HP/Extended Abstract/4.10_LIU_Timothy.pdf

Liu, W.T., and Tang, W., 2005. Estimating moisture transport over oceans using space-based observations. Journal of Geophysical Research: Atmospheres, 110(D10):D10101. http://dx.doi.org/10.1029/2004JD005300

Liu, W.T., Zhang, A., and Bishop, J.K.B., 1994. Evaporation and solar irradiance as regulators of sea surface temperature in annual and interannual changes. Journal of Geophysical Research: Oceans, 99(C6):12623-12637. http://dx.doi.org/10.1029/94JC00604

Liu, X., Liu, Z., Kutzbach, J.E., Clemens, S.C., and Prell, W.L., 2006. Hemispheric insolation forcing of the Indian Ocean and Asian monsoon: local versus remote impacts. Journal of Climate, 19(23):6195-6208. http://dx.doi.org/10.1175/JCLI3965.1

Locarnini, R.A., Mishonov, A.V., Antonov, J.I., Boyer, T.P., Garcia, H.E., Baranova, O.K., Zweng, M.M., and Johnson, D.R., 2010. World Ocean Atlas 2009 (Volume 1): Temperature. In Levitus, S. (Ed.), NOAA Atlas NESDIS 68: Washington, DC (U.S. Government Printing Office). ftp://ftp.nodc.noaa.gov/pub/WOA09/DOC/woa09_vol1_text_ figures.pdf

Loschnigg, J., and Webster, P.J., 2000. A coupled ocean-atmosphere system of SST modulation for the Indian Ocean. Journal of Climate, 13(19):33423360. http://dx.doi.org/10.1175/15200442(2000)013<3342:ACOASO >2.0.CO;2

Mantyla, A.W., and Reid, J.L., 1995. On the origins of deep and bottom waters of the Indian Ocean. Journal of Geophysical Research: Oceans, 100(C2):2417-2439. http://dx.doi.org/10.1029/94JC02564 
Misra, S., and Froelich, P.N., 2012. Lithium isotope history of Cenozoic seawater: changes in silicate weathering and reverse weathering. Science, 335(6070):818-823. http://dx.doi.org/10.1126/science.1214697

Molnar, P., 2005. Mio-Pliocene growth of the Tibetan Plateau and evolution of East Asian climate. Palaeontologia Electronica, 8(1):1-23. http://palaeo-electronica.org/2005_1/molnar2/molnar2.pdf

Molnar, P., Boos, W.R., and Battisti, D.S., 2010. Orographic controls on climate and paleoclimate of Asia: thermal and mechanical roles for the Tibetan Plateau. Annual Review of Earth and Planetary Sciences, 38(1):77-102. http://dx.doi.org/10.1146/annurev-earth-040809-152456

Mudelsee, M., and Raymo, M.E., 2005. Slow dynamics of the Northern Hemisphere glaciation. Paleoceanography, 20(4):PA4022. http://dx.doi.org/10.1029/2005PA001153

Nicholls, R.J., Wong, P.P., Burkett, V., Codignotto, J., Hay, J., McLean, R., Ragoonaden, S., and Woodroffe, C.D., 2007. Coastal systems and lowlying areas. In Parry, M.L., Canziani, O.F., Palutikof, J.P., van der Linden, P.J., and Hanson, C.E. (Eds.), Climate Change 2007: Impacts, Adaptation and Vulnerability. Contribution of Working Group II to the Fourth Assessment Report of the Intergovernmental Panel on Climate Change: Cambridge, United Kingdom (Cambridge University Press), 315-356. https://www.ipcc.ch/pdf/assessment-report/ar4/wg2/ar4-wg2chapter6.pdf

Ninkovich, D., 1979. Distribution, age and chemical composition of tephra layers in deep-sea sediments off western Indonesia. Journal of Volcanology and Geothermal Research, 5(1-2):67-86.

http://dx.doi.org/10.1016/0377-0273(79)90033-7

Ninkovich, D., Shackelton, N.J., Abdel-Monem, A.A., Obradovich, J.D., and Izett, G., 1978. K-Ar age of the Late Pleistocene eruption of Toba, north Sumatra. Nature, 276(5688):574-577. http://dx.doi.org/0.1038/276574a0

Park, S.-C., Sohn, B.-J., and Wang, B., 2007. Satellite assessment of divergent water vapor transport from NCEP, ERA40, and JRA25 reanalyses over the Asian summer monsoon region. Journal of the Meteorological Society of Japan, 85(5):615-632. http://dx.doi.org/10.2151/jmsj.85.615

Peirce, J., Weissel, J., et al., 1989. Proceedings of the Ocean Drilling Program, Initial Reports, 121: College Station, TX (Ocean Drilling Program). http://dx.doi.org/10.2973/odp.proc.ir.121.1989

Phillips, S.C., Johnson, J.E., Giosan, L., and Rose, K., 2014a. Monsoon-influenced variation in productivity and lithogenic sediment flux since $110 \mathrm{ka}$ in the offshore Mahanadi Basin, northern Bay of Bengal. Marine and Petroleum Geology, 58(Part A):502-525. http://dx.doi.org/10.1016/j.marpetgeo.2014.05.007

Phillips, S.C., Johnson, J.E., Underwood, M.B., Guo, J., Giosan, L., and Rose, K., 2014b. Long-timescale variation in bulk and clay mineral composition of Indian continental margin sediments in the Bay of Bengal, Arabian Sea, and Andaman Sea. Marine and Petroleum Geology, 58(Part A):117-138. http://dx.doi.org/10.1016/j.marpetgeo.2014.06.018

Ponton, C., Giosan, L., Eglinton, T.I., Fuller, D.Q., Johnson, J.E., Kumar, P., and Collett, T.S., 2012. Holocene aridification of India. Geophysical Research Letters, 39(3):L3407. http://dx.doi.org/10.1029/2011GL050722

Powell, C.McA., Roots, S.R., and Veevers, J.J., 1988. Pre-breakup continental extension in East Gondwanaland and the early opening of the eastern Indian Ocean. Tectonophysics, 155(1-4):261-283. http://dx.doi.org/10.1016/0040-1951(88)90269-7

Prell, W.L., Murray, D.W., Clemens, S.C., and Anderson, D.M., 1992. Evolution and variability of the Indian Ocean summer monsoon: evidence from the western Arabian Sea drilling program. In Duncan, R.A., Rea, D.K., Kidd, R.B., von Rad, U., and Weissel, J.K. (Eds.), Synthesis of Results from Scientific Drilling in the Indian Ocean. Geophysical Monograph, 70:447469. http://dx.doi.org/10.1029/GM070p0447

Quade, J., and Cerling, T.E., 1995. Expansion of $\mathrm{C}_{4}$ grasses in the late Miocene of northern Pakistan: evidence from stable isotopes in paleosols. Palaeogeography, Palaeoclimatology, Palaeoecology, 115(1-4):91-116. http://dx.doi.org/10.1016/0031-0182(94)00108-K
Ramana, M.V., Ramprasad, T., Collett, T.S., Kumar, P., Boswell, R.M., Riedel, M., Sathe, A.V., Lall, M., Vishwanath, K., Muzumdar, A., Sain, K., and Cochran, J. (Eds.), 2014. Geologic Implications of Gas Hydrates in the Offshore of India: Results of the National Gas Hydrate Program Expedition 01, Marine and Petroleum Geology, 58(Part A). http://www.science direct.com/science/journal/02648172/58/supp/PA

Randall, D.A., Wood, R.A., Bony, S., Colman, R., Fichefet, T., Fyfe, J., Kattsov, V., Pitman, A., Shukla, J., Srinivasan, J., Stouffer, R.J., Sumi, A., and Taylor, K.E., 2007. Climate models and their evaluation. In Solomon, S., Qin, D., Manning, M., Chen, Z., Marquis, M., Averyt, K.B., Tingor, M., and Miller, H.L. (Eds.), Climate Change 2007: The Physical Science Basis. Contribution of Working Group I to the Fourth Assessment Report of the Intergovernmental Panel on Climate Change: Cambridge, UK (Cambridge University Press), 589-662. http://www.ipcc.ch/pdf/assessmentreport/ar4/wg1/ar4-wg1-chapter8.pdf

Rayner, N.A., Parker, D.E., Horton, E.B., Folland, C.K., Alexander, L.V., Rowell, D.P., Kent, E.C., and Kaplan, A., 2003. Global analyses of sea surface temperature, sea ice, and night marine air temperature since the late nineteenth century. Journal of Geophysical Research: Atmospheres, 108(D14):4407. http://dx.doi.org/10.1029/2002JD002670

Rodriguez, M., Chamot-Rooke, N., Huchon, P., Fournier, M., and Delescluse, M., 2014. The Owen Ridge uplift in the Arabian Sea: implications for the sedimentary record of Indian monsoon in late Miocene. Earth and Planetary Science Letters, 394:1-12. http://dx.doi.org/10.1016/j.epsl.2014.03.011

Royer, J.-Y., Peirce, J.W., and Weissel, J.K., 1991. Tectonic constraints on the hotspot formation of the Ninetyeast Ridge. In Weissel, J., Peirce, J., Taylor, E., Alt, J., et al., Proceedings of the Ocean Drilling Program, Scientific Results, 121: College Station, TX (Ocean Drilling Program), 763-776. http://dx.doi.org/10.2973/odp.proc.sr.121.122.1991

Ruddiman, W.F., 2006. What is the timing of orbital-scale monsoon changes? Quaternary Science Reviews, 25(7-8):657-658. http://dx.doi.org/10.1016/j.quascirev.2006.02.004

Ryan, W.B.F., Carbotte, S.M., Coplan, J.O., O'Hara, S., Melkonian, A., Arko, R., Weissel, R.A., Ferrini, V., Goodwillie, A., Nitsche, F., Bonczkowski, J., and Zemsky, R., 2009. Global multi-resolution topography synthesis. Geochemistry, Geophysics, Geosystems, 10(3):Q03014. http://dx.doi.org/10.1029/2008GC002332

Sager, W.W., Paul, C.F., Krishna, K.S., Pringle, M., Eisin, A.E., Frey, F.A., Gopala Rao, D., and Levchenko, O., 2010. Large fault fabric of the Ninetyeast Ridge implies near-spreading ridge formation. Geophysical Research Letters, 37(17):L17304. http://dx.doi.org/10.1029/2010GL044347

Schlitzer, R., 2000. Electronic atlas of WOCE hydrographic and tracer data now available. Eos, Transactions American Geophysical Union, 81(5):45. http://dx.doi.org/10.1029/00EO00028

Schmittner, A., Galbraith, E.D., Hostetler, S.W., Pedersen, T.F., and Zhang, R., 2007. Large fluctuations of dissolved oxygen in the Indian and Pacific Oceans during Dansgaard-Oeschger oscillations caused by variations of North Atlantic Deep Water subduction. Paleoceanography, 22(3):PA3207. http://dx.doi.org/10.1029/2006PA001384

Schott, F.A., and McCreary, J.P., Jr., 2001. The monsoon circulation of the Indian Ocean. Progress in Oceanography, 51(1):1-123. http://dx.doi.org/10.1016/S0079-6611(01)00083-0

Schott, F.A., Xie, S.-P., and McCreary, J.P.,Jr., 2009. Indian Ocean circulation and climate variability. Reviews of Geophysics, 47(1):RG1002. http://dx.doi.org/10.1029/2007RG000245

Schulz, H., von Rad, U., and Erlenkeuser, H., 1998. Correlation between Arabian Sea and Greenland climate oscillations of the past 110,000 years. Nature, 393(6680):54-57. http://dx.doi.org/10.1038/31750

Schwenk, T., and Spieß, V., 2009. Architecture and stratigraphy of the Bengal Fan as response to tectonic and climate revealed from high-resolution seismic data. In Kneller, B.C., Martinsen, O.J., and McCaffrey, B. (Eds.), External Controls on Deep-Water Depositional Systems. Special Publication - SEPM (Society of Sedimentary Geologists), 92:107-131. 
Scotese, C.R., Gahagan, L.M., and Larson, R.L., 1988. Plate tectonic reconstructions of the Cretaceous and Cenozoic ocean basins. Tectonophysics, 155(1-4):27-48. http://dx.doi.org/10.1016/0040-1951(88)90259-4

Sharmila, S., Joseph, S., Sahai, A.K., Abhilash, S., and Chattopadhyay, R., 2015. Future projection of Indian summer monsoon variability under climate change scenario: an assessment from CMIP5 climate models. Global and Planetary Change, 124:62-78. http://dx.doi.org/10.1016/j.gloplacha.2014.11.004

Shipboard Scientific Party, 1989. Site 758. In Peirce, J., Weissel, J., et al., Proceedings of the Ocean Drilling Program, Initial Reports, 121: College Station, TX (Ocean Drilling Program), 359-453.

http://dx.doi.org/10.2973/odp.proc.ir.121.112.1989

Simmonds, I., Bi, D., and Hope, P., 1999. Atmospheric water vapor flux and its association with rainfall over China in summer. Journal of Climate, 12(5):1353-1367. http://dx.doi.org/10.1175/15200442(1999)012<1353:AWVFAI >2.0.CO;2

Singh, A., Jani, R.A., and Ramesh, R., 2010. Spatiotemporal variations of the $\delta^{18} \mathrm{O}-$ salinity relation in the northern Indian Ocean. Deep Sea Research, Part I, 57(11):1422-1431. http://dx.doi.org/10.1016/j.dsr.2010.08.002

Singh, A.D., Jung, S.J.A., Darling, K., Ganeshram, R., Ivanochko, T., and Kroon, D., 2011. Productivity collapses in the Arabian Sea during glacial cold phases. Paleoceanography, 26(3):PA3210. http://dx.doi.org/10.1029/2009PA001923

Singh, R.K., and Gupta, A.K., 2005. Systematic decline in benthic foraminiferal species diversity linked to productivity increases over the last $26 \mathrm{Ma}$ in the Indian Ocean. Journal of Foraminiferal Research, 35(3):219-227. http://dx.doi.org/10.2113/35.3.219

Singh, S.C., Moeremans, R., McArdle, J., and Johansen, K., 2013. Seismic images of the sliver strike-slip fault and back thrust in the AndamanNicobar region. Journal of Geophysical Research: Solid Earth, 118(10):5208-5224. http://dx.doi.org/10.1002/jgrb.50378

Stöckli, R., Vermote, E., Saleous, N., Simmon, R., and Herring, D., 2005. The Blue Marble Next Generation-A true color Earth dataset including seasonal dynamics from MODIS. NASA Earth Observatory. http://earthobservatory.nasa.gov/Features/BlueMarble/bmng.pdf

Stoll, H.M., Vance, D., and Arevalos, A., 2007. Records of the Nd isotope composition of seawater from the Bay of Bengal: implications for the impact of Northern Hemisphere cooling on ITCZ movement. Earth and Planetary Science Letters, 255(1-2):213-228. http://dx.doi.org/10.1016/j.epsl.2006.12.016

Subrahmanyam, V., Subrahmanyam, A.S., Murty, G.P.S., and Murthy, K.S.R., 2008. Morphology and tectonics of Mahanadi Basin, northeastern continental margin of India from geophysical studies. Marine Geology, 253(12):63-72. http://dx.doi.org/10.1016/j.margeo.2008.04.007

Sun, X., and Wang, P., 2005. How old is the Asian monsoon system?-Palaeobotanical records from China. Palaeogeography, Palaeoclimatology, Palaeoecology, 222(3-4):181-222. http://dx.doi.org/10.1016/j.palaeo.2005.03.005

Sun, Y., Clemens, S.C., Morrill, C., Lin, X., Wang, X., and An, Z., 2011. Influence of Atlantic meridional overturning circulation on the East Asian winter monsoon. Nature Geoscience, 5(1):46-49. http://dx.doi.org/10.1038/ngeo1326

Thomas, D.J., Bralower, T.J., and Jones, C.E., 2003. Neodymium isotopic reconstruction of late Paleocene-early Eocene thermohaline circulation. Earth and Planetary Science Letters, 209(3-4):309-322. http://dx.doi.org/10.1016/S0012-821X(03)00096-7

Tomczak, M., and Godfrey, J.S., 2003. Regional Oceanography: An Introduction (2nd ed.): Delhi (Daya Publishing House).

Varkey, M.J., Murty, V.S.N., and Suryanarayana, A., 1996. Physical oceanography of the Bay of Bengal and Andaman Sea. Oceanography and Marine Biology, 34:1-70. http://drs.nio.org/drs/handle/2264/2276

von der Borch, C.C., Sclater, J.G., et al., 1974. Initial Reports of the Deep Sea Drilling Project, 22: Washington, DC (U.S. Government Printing Office). http://dx.doi.org/10.2973/dsdp.proc.22.1974
Wajsowicz, R.C., and Schopf, P.S., 2001. Oceanic influences on the seasonal cycle in evaporation over the Indian Ocean. Journal of Climate,

14(6):1199-1226. http://dx.doi.org/10.1175/15200442(2001)014<1199:OIOTSC >2.0.CO;2

Wang, P., Clemens, S., Beaufort, L., Braconnot, P., Ganssen, G., Jian, Z., Kershaw, P., and Sarnthein, M., 2005. Evolution and variability of the Asian monsoon system: state of the art and outstanding issues. Quaternary Science Review, 24(5-6):595-629. http://dx.doi.org/10.1016/j.quascirev.2004.10.002

Wang, Y., Cheng, H., Edwards, R.L., Kong, X., Shao, X., Chen, S., Wu, J., Jiang, X., Wang, X., and An, Z., 2008. Millennial- and orbital-scale changes in the East Asian monsoon over the past 224,000 years. Nature, 451(7182):1090-1093. http://dx.doi.org/10.1038/nature06692

Wang, Y.J., Cheng, H., Edwards, R.L., An, Z.S., Wu, J.Y., Shen, C.-C., and Dorale, J.A., 2001. A high-resolution absolute-dated late Pleistocene monsoon record from Hulu Cave, China. Science, 294(5580):2345-2348. http://dx.doi.org/10.1126/science.1064618

Webster, P.J., 1987a. The elementary monsoon. In Fein, J.S., and Stephens, P.L. (Eds.), Monsoons: New York (Wiley), 3-32.

Webster, P.J., 1987b. The variable and interactive monsoon. In Fein, J.S., and Stephens, P.L. (Eds.), Monsoons: New York (Wiley), 269-330.

Webster, P.J., 1994. The role of hydrological processes in ocean-atmosphere interactions. Reviews of Geophysics, 32(4):427-476. http://dx.doi.org/10.1029/94RG01873

Webster, P.J., Magaña, V.O., Palmer, T.N., Shukla, J., Tomas, R.A., Yanai, M., and Yasunari, T., 1998. Monsoons: processes, predictability, and the prospects for prediction. Journal of Geophysical Research: Oceans, 103(C7):14451-14510. http://dx.doi.org/10.1029/97JC02719

Wyrtki, K., 1971. Oceanographic Atlas of the International Ocean Expedition. National Science Foundation.

Xie, P., and Arkin, P.A., 1997. Global precipitation: a 17-year monthly analysis based on gauge observations, satellite estimates, and numerical model outputs. Bulletin of the American Meteorological Society, 78(11):25392558. http://dx.doi.org/10.1175/15200477(1997)078<2539:GPAYMA >2.0.CO;2

Xu, J., Kuhnt, W., Holbourn, A., Andersen, N., and Bartoli, G., 2006. Changes in the vertical profile of the Indonesian Throughflow during Termination II: evidence from the Timor Sea. Paleoceanography, 21(4):PA4202. http://dx.doi.org/10.1029/2006PA001278

Yancheva, G., Nowaczyk, N.R., Mingram, J., Dulski, P., Schettler, G., Negendank, J.F.W., Liu, J., Sigman, D.M., Peterson, L.C., and Haug, G.H., 2007. Influence of the intertropical convergence zone on the East Asian monsoon. Nature, 445(7123):74-77. http://dx.doi.org/10.1038/nature05431

You, Y., and Tomczak, M., 1993. Thermocline circulation and ventilation in the Indian Ocean derived from water mass analysis. Deep Sea Research, Part I, 40(1):13-56. http://dx.doi.org/10.1016/0967-0637(93)90052-5

Zachos, J., Pagani, M., Sloan, L., Thomas, E., and Billups, K., 2001. Trends, rhythms, and aberrations in global climate $65 \mathrm{Ma}$ to present. Science, 292(5517):686-693. http://dx.doi.org/10.1126/science.1059412

Zachos, J.C., Flower, B.P., and Paul, H., 1997. Orbitally paced climate oscillations across the Oligocene/Miocene boundary. Nature, 388(6642):567570. http://dx.doi.org/10.1038/41528

Zhu, Y., and Newell, R.E., 1998. A proposed algorithm for moisture fluxes from atmospheric rivers. Monthly Weather Review, 126(3):725-735. http://dx.doi.org/10.1175/15200493(1998) 126<0725:APAFMF > 2.0.CO;2

Ziegler, M., Lourens, L.J., Tuenter, E., Hilgen, F., Reichart, G.-J., and Weber, N., 2010. Precession phasing offset between Indian summer monsoon and Arabian Sea productivity linked to changes in Atlantic overturning circulation. Paleoceanography, 25(3):PA3213. http://dx.doi.org/10.1029/2009PA001884 